(Editores)

Daniel Barredo Ibáñez

Mágda Rodrigues da Cunta Jorge Hidalgo Toledo

\title{
Jóvenes, participación y medios de comunicación digitales en América Latina
}

Cuadernos Artesanos de Comunicación / 156

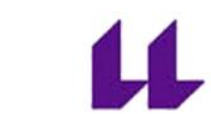

Universidad de La Laguna
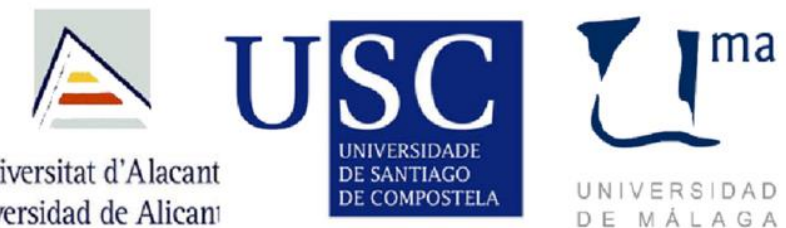

UNIVERSIDAD

DE M Á A G A

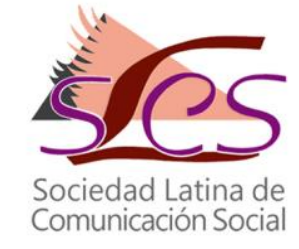




\title{
Cuadernos Artesanos de Comunicación \\ Coordinador editorial: José Manuel de Pablos - jpablos@,ull.edu.es \\ Comité Científico \\ Presidencia: José Luis Piñuel Raigada (UCM) \\ Secretaría: Milena Trenta
}

- Ramón Zallo (Universidad del País Vasco, UPV-EHU)

- Núria Almiron (Universidad Pompeu Fabra, UPF)

- Francisco Campos Freire (Universidad de Santiago de Compostela)

- José Cisneros (Benemérita Universidad Autónoma de Puebla, BUAP)

- Bernardo Díaz Nosty (Universidad de Málaga, UMA)

- Carlos Elías (Universidad Carlos III de Madrid, UC3M)

- Paulina B. Emanuelli (Universidad Nacional de Córdoba, UNC)

- José Luis González Esteban (Universitas Miguel Hernández de Elche, UMH)

- Marisa Humanes (Universidad Rey Juan Carlos, URJC)

- Juan José Igartua (Universidad de Salamanca, USAL)

- Xosé López (Universidad de Santiago de Compostela)

- Maricela López-Ornelas (Universidad Autónoma de Baja California, UABC)

- Octavio Islas (Universidad de los Hemisferios, Ecuador)

- Javier Marzal (Universidad Jaume I, UJI)

- José Antonio Meyer (Benemérita Universidad Autónoma de Puebla, BUAP)

- Ramón Reig (Universidad de Sevilla, US)

- Miquel Rodrigo Alsina (Universidad Pompeu Fabra, UPF)

- Xosé Soengas (Universidad de Santiago de Compostela)

- José Luis Terrón (Universidad Autónoma de Barcelona, UAB)

- José Miguel Túñez (Universidad de Santiago, USC)

- Victoria Tur (Universidad de Alicante, UA)

- Miguel Vicente (Universidad de Valladolid, UVA)

\begin{abstract}
* Queda expresamente autorizada la reproducción total o parcial de los textos publicados en este libro, en cualquier formato o soporte imaginables, salvo por explícita voluntad en contra del autor o autora o en caso de ediciones con ánimo de lucro. Las publicaciones donde se incluyan textos de esta publicación serán ediciones no comerciales y han de estar igualmente acogidas a Creative Commons. Harán constar esta licencia y el carácter no venal de la publicación.
\end{abstract}

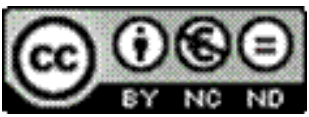

Este libro y cada uno de los capítulos que contiene (en su caso), así como las imágenes incluidas, si no se indica lo contrario, se encuentran bajo una Licencia Creative Commons Atribución-No Comercial-Sin Derivadas 3.0 Unported. Puede ver una copia de esta licencia en http://creativecommons.org/licenses/by-nc-nd/3.0/ Esto significa que Ud. es libre de reproducir y distribuir esta obra, siempre que cite la autoría, que no se use con fines comerciales o lucrativos y que no haga ninguna obra derivada. Si quiere hacer alguna de las cosas que aparecen como no permitidas, contacte con los coordinadores del libro o con el autor del capítulo correspondiente.

\footnotetext{
* La responsabilidad de cada texto es de su autor o autora.
} 
Daniel Barredo Ibáñez, Mágda Rodrigues da Cunha, Jorge Hidalgo Toledo (Editores)

\section{Jóvenes, participación y medios de comunicación digitales en América Latina}

Daniel Barredo Ibáñez/Mágda Rodrigues da Cunha/Jorge Hidalgo

Toledo/Jorge Alberto Hidalgo Toledo/Antonio GarcíaJiménez/Beatriz Catalina-García/Manuel Montes-

Vozmediano/Daniel Javier de la Garza Montemayor/Úrsula FreundtThurne/Tiago Luís Rigo/Enrique Iturralde Chaparro/Sergio Rivera

Magos/Bruno Carriço Reis/Malvina Eugenia Rodríguez

Cuadernos Artesanos de Comunicación / 156
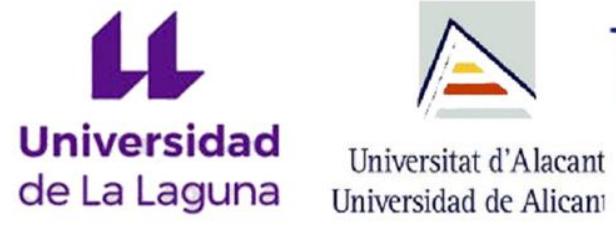

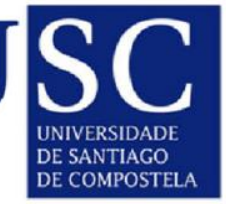

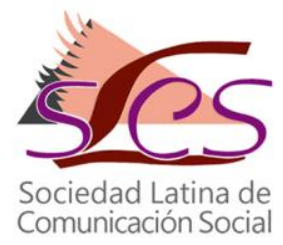


CAC $156^{\circ}$ - Jóvenes, participación y medios de comunicación digitales en América Latina

Editoras/es | Daniel Barredo Ibáñez, Mágda Rodrigues da Cunha, Jorge Hidalgo Toledo.

Precio social: $7,95 € \mid$ Precio en librería 10,35€ |

Editores: Javier Herrero y Milena Trenta

Diseño: F. Drago

Ilustración de portada: Fragmento del cuadro "Mujer de Fuenteventura", de Vale (Bolonia).

Imprime y distribuye: F. Drago. Andocopias S. L.

c/ La Hornera, 41. La Laguna. Tenerife.

Teléfono: 922250554 | fotocopiasdrago@,telefonica.net

Edita: Sociedad Latina de Comunicación Social - edición no venal - La Laguna (Tenerife), 2019 - Creative Commons

http://www.revistalatinacs.org/14SLCS/portada2014.html

Descargar en pdf:

http://www.cuadernosartesanos.org/\#cac156

Protocolo de envío de manuscritos con destino a CAC:

http://www.cuadernosartesanos.org/protocolo.html

ISBN -978-84-17314-15-6

DL: TF-432-2019

DOI: $10.4185 / \operatorname{cac} 156$ 


\title{
Jóvenes, participación y medios de comunicación digitales en América Latina
}

\author{
Daniel Barredo Ibáñez \\ Mágda Rodrigues da Cunha \\ Jorge Hidalgo Toledo (Editores)
}

\begin{abstract}
Este libro, resultado colectivo del Grupo temático 19 Comunicación digital, redes y procesos, de la Asociación Latinoamericana de Investigadores en Comunicación (ALAIC), a través de 7 capítulos de autores procedentes de México, España, Colombia, Perú, Brasil, Portugal y Argentina, presenta una discusión alrededor de las prácticas de participación de los jóvenes en los medios en línea, desde distintos enfoques epistémicos, algo propio de un contexto tan diverso como el latinoamericano. Se aborda, en concreto, la hiperconexión de las juventudes; la descripción de los riesgos y de las vulnerabilidades de los usuarios menores de edad; el capital social y la eficacia política que se vinculan a la interacción digital; la relación entre participación en línea y fuera de línea, entre otros.
\end{abstract}

\section{Keywords}

Participación ciudadana, Medios en línea, América Latina, Usuarios jóvenes

Forma de citar este libro:

Barredo Ibáñez, D.; Cunha, M. R. \& Hidalgo Toledo, J. (Eds.) (2019). Jóvenes, participación y medios de comunicación digitales en América Latina. La Laguna, España: Cuadernos Artesanos de Comunicación, cac 156. La Laguna (Tenerife): Latina. 


\section{Índice}

Introducción

Capítulo 1 - Jóvenes hipermediales: hipermediatización del Yo y las juventudes hiperconectadas ....................................................................17

Capítulo 2 - Percepciones sobre el comportamiento comunicacional y las vulnerabilidades digitales de los menores. Cruce interdisciplinar.47

Capítulo 3 - Participación, capital social y eficacia política: una encuesta comparativa a los universitarios de México y Chile

Capítulo 4 - Os jovens brasileiros e a movimentação entre tribos digitais.

Capítulo 5 - Chairos contra Derechairos: El trolling y otras prácticas incendiarias de la comunicación en línea en un grupo temático sobre Historia, en Facebook

Capítulo 6 - Jóvenes mexicanos en contexto digital: prácticas online que llevan a riesgos

Capítulo 7 - Estar en las redes para salir de las redes: comunidades sociodigitales y participación ciudadana en Argentina. 165

El contenido de este libro ha sido sometido a un proceso de revisión de doble ciego por pares, semejante al sistema de revisión de un artículo científico para un journal. 
La edición de este libro ha sido financiada por el proyecto de $\mathrm{I}+\mathrm{D}$ "Esfera pública y participación ciudadana", con código PIN-2017-007, dirigido por el profesor Daniel Barredo y con financiación del fondo de proyectos de Gran Cuantía de la Universidad del Rosario (2017 2019). Los capítulos que se presentan a continuación fueron difundidos parcialmente como ponencias en el Grupo Temático 19 Comunicación Digital, Redes y Procesos, en el marco del XIV Congreso de la Asociación Latinoamericana de Investigadores de la Comunicación: Comunicación en sociedades diversas. Horizontes de inclusión, equidad y democracia, celebrado del 30 de julio al 1 de agosto de 2018 en la Universidad de Costa Rica. 
A Carlos Arcila, Cosette Castro y Mabel Calderín, impulsores del GT 19 Comunicación digital, redes y procesos, por su invaluable tarea para promocionar la investigación en medios digitales en América Latina. 


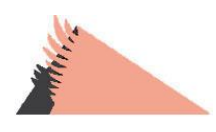

\title{
Introducción
}

\section{La participación de los jóvenes latinoamericanos en los medios en línea, una discusión desde el GT19}

\author{
Daniel Barredo Ibáñez. Universidad del Rosario (Colombia) \\ Mágda Rodrigues da Cunha. Pontifícia Universidade Católica do Rio \\ Grande do Sul (Brasil) \\ Jorge Hidalgo Toledo. Universidad Anáhuac (México)
}

¿UÉ SIGNIFICA ser joven en la era digital? ¿En qué medida la condición juvenil se ha apropiado de los medios de comunicación como su hábitat natural de coexistencia y socialización? ¿Cómo dieron el brinco cuántico de audiencias, usuarios, consumidores y fans a prosumidores y co-constructores de sentido? ¿Qué tipo nuevas agencias y prácticas performativas dejan entrever estos actores mediáticos? ¿Qué características tienen sus habitus?

La historia de la investigación en comunicación ha tenido presente desde sus orígenes los modos de articulación, recepción y consumo mediático de las diversas poblaciones y grupos etarios. Desde los inicios de la disciplina se registraron a las jóvenes audiencias como grupos altamente consumidores de medios al grado de que éstos desplazaron la autoridad de padres de familia e instituciones como la escuela o las iglesias. Para los jóvenes, los medios se habían convertido en un pasatiempo significativo que ha llegado a ocupar el cien por ciento del tiempo libre de sus vidas. Los medios son hoy día un gran recurso de expresión y socialización que les permite impactar de modo profundo en la cultura, la política y la economía. 
La hipermediatización de la vida y la cultura ha hecho que todos los procesos de comunicación, interacción y socialización estén mediados por dispositivos tecnológicos. Los medios e hipermedios son hoy el principal recurso simbólico que tienen para distinguir, definir, diferenciar, interpelar, interpretar y relacionar sus identidades. Es en los medios y desde los medios desde donde logran encontrarle sentido al mundo en el que viven.

Los mismos medios han hecho visibles los espacios de representación, estetización y praxis de los jóvenes. Es por ello que a lo largo de la historia de la comunicación los abordajes teóricos para la investigación sobre los jóvenes y su relación con los medios han seguido múltiples líneas de investigación. Algunas de las principales son:

1) Los estudios derivados de la preocupación por los derechos de los jóvenes y la manera como los medios les influyen;

2) Las investigaciones que analizan la violencia mediática y la protección de los jóvenes y niños como audiencias vulnerables;

3) Los trabajos que profundizan en las identidades juveniles en el corazón de la ecología mediática;

4) El análisis de los teen media y cómo estos aportan visiones del mundo;

5) Las indagaciones que profundizan en los medios como interfaces liberadoras que permiten empoderamiento, participación y generación de cambio social, cultural, político e ideológico;

6) La vinculación entre consumo cultural y culturas juveniles;

7) Exploraciones sobre las prácticas, expresiones y producciones en los entornos urbanos, laborales, religiosos, mediáticos y corporales;

8) Las pesquisas entorno a los medios y su rol en el proceso educativo y alfabetizador llámese Educación con los medios y la recepción crítica: Educación para los medios;

9) Cercana a esta línea de investigación se encuentra la alfabetización digital donde se ubican los trabajos que contemplan e-competencias, el instruccionismo tecnológico y la interacción digital de las audiencias.

10) Aunada a esta línea están las exploraciones cercanas a las agendas sociales como género, migración, globalización, desigualdades, marginación y pobreza y el uso que hacen los 
jóvenes para tratar de reducir las brechas producto de la sociedad de la información.

Como puede verse, los abordajes históricos se han realizado desde la multidisciplina; antropología, sociología, historia, educación psicología social han coqueteado fuertemente con los estudios sobre juventud. El presente texto busca continuar la discusión sobre consumo cultural, culturas juveniles y ecología de medios sumando ciencias de datos, ciencias políticas, telecomunicaciones, migración digital y network analysis.

La alta concentración mediática en la vida juvenil ha hecho que la investigación se diferencie de las visiones anteriores donde se identificaban muchas de estas prácticas como contraculturales. La juventud ha invitado desde siempre a explorarse más allá de la dimensión biológica, psicológica y social.

Por otra parte, el ecosistema mediático contemporáneo parece dividido en dos esferas reconocibles: de una parte, los medios de comunicación adaptados a Internet, que introducen los temas de unas agendas pensadas en las décadas anteriores a la esfera digital. Y, de otra parte, los medios nativos digitales y los medios sociales, como principales enclaves en los que se concentran los usuarios de menores edades. Unos medios anclados al consumo, a las audiencias pasivas; otros medios que hibridan consumo y producción, y consideran que sus receptores son usuarios activos. Los unos, donde el periodista o el comunicador es la estrella; los otros, centrados sobre todo en el usuario. Unos medios, que conservan todavía la credibilidad como valor característico; los otros, a menudo identificados por las fake news y por sus problemas de acreditación de la calidad. Unos medios serios, para grupos adultos; otros, en cambio, relacionados al entretenimiento, para grupos de jóvenes.

Mediante este ejercicio de simplificación, observamos que, en el fondo, existe una crisis de innovación en el periodismo contemporáneo ante los desafíos que emergen en el marco de unas sociedades que, como las latinoamericanas, se están transformando rápidamente con el impulso tecnológico. Crisis de innovación: los unos, frente a la 
incapacidad de incorporar las nuevas lógicas y rutinas de interacción; los otros, enfrentados a las dificultades de incorporar los viejos valores del periodismo (verificación, contrastación, entre otros), en los nuevos dispositivos y prácticas.

Y detrás de la crisis de innovación, está un factor que es altamente importante, como es la participación de los jóvenes en los entornos en línea. Por ello, desde el Grupo temático 19 Comunicación digital, redes y procesos de la Asociación Latinoamericana de Investigadores en Comunicación (ALAIC), proponemos 7 capítulos que pueden ser relevantes para entender dicho fenómeno en las juventudes de esta parte del mundo. El libro, como es habitual en un contexto tan diverso como América Latina, presenta distintos enfoques y corrientes epistémicas, de modo que son los lectores los encargados de atrapar los significados desde una presencia basada en el crisol.

En el primer capítulo, Jorge Alberto Hidalgo Toledo (Universidad Anáhuac, México), describe el nuevo escenario de participación en que se desenvuelven los jóvenes. De acuerdo al autor, en el caso concreto de los jóvenes, el espacio mediático no puede desligarse del llamado espacio juvenil, en tanto que aquel es responsable de construir la experiencia de estos usuarios. Es más, para este perfil poblacional, los hipermedios -aquellos que se identifican, sobre todo, por el uso de las TIC-, han desplazado incluso a los medios convencionales. Por ello, emerge una nueva dimensión de análisis a tener en cuenta: "la condición mediatizada", que alude a la estructuración y reconfiguración de las prácticas juveniles a partir de la influencia de los medios.

En el segundo capítulo, Antonio García-Jiménez, Beatriz Catalina García y Manuel Montes Vozmediano, de la Universidad Rey Juan Carlos (España), explora las percepciones de los estudiantes de educación primaria, así como de los estudiantes de posgrado en comunicación, sobre las rutinas asociadas a las tecnologías, sus riesgos y posibles prevenciones en su manejo. Entre los resultados de este trabajo, los autores aseguran que los jóvenes abordados subrayan las posibilidades que se expanden a partir de los distintos dispositivos y plataformas tecnológicas, como herramientas para los procesos de enseñanza y aprendizaje. Sin embargo, algunos de los integrantes de los 
grupos de discusión, se manifestaron en contra de esa afirmación, dado que muchos de los contenidos difundidos desde esos espacios no pueden ser contrastados. Por ello, la labor de mediación de los docentes, de los padres, de los hermanos puede ser fundamental en la adquisición de competencias por parte de los menores.

En el tercer capítulo, Daniel de la Garza (Universidad Autónoma de Nuevo León, México), Daniel Barredo Ibáñez (Universidad del Rosario, Colombia) y Úrsula Freundt-Thurne (Universidad Peruana de Ciencias Aplicadas, Perú), estudian la relación entre la participación, el capital social y el sentimiento de eficacia política de los jóvenes de dos países latinoamericanos, como son México y Chile. Tras encuestar a 1100 jóvenes de Chile, y a 1239 jóvenes de México, los autores encuentran algunas diferencias interesantes: en el caso de los jóvenes chilenos, la eficacia política es percibida menor en comparación con los mexicanos, quienes tienen un concepto de participación menos desarrollado, quizá por ciertas características de ese país, como es la concentración mediática en dos corporaciones televisivas -Televisa y TV Azteca-, y la desafección propia de ese sistema democrático. En las conclusiones, y a raíz de los resultados obtenidos, los autores proponen un mayor incentivo de iniciativas relacionadas con la participación en línea en ambos países, algo que ayudaría a mitigar los bajos niveles de interacción reconocidos por los estudiantes encuestados.

En el cuarto capítulo, Tiago Luís Rigo y Mágda Rodrigues da Cunha, de la Pontifícia Universidade Católica do Rio Grande do Sul (Brasil), indagan sobre la migración de los jóvenes de Facebook a otros medios sociales. Con este objetivo, los autores emplean datos procedentes de estudios cuantitativos y cualitativos, especialmente a través de las obras del sociólogo Michel Maffesoli. En los resultados, los autores indican que los jóvenes tienden a abandonar Facebook dada la saturación que perciben, con la pérdida de tiempo, las polémicas que circulan por esta red social y el hecho de que es una plataforma identificada con grupos etarios de mayor edad. En conclusión, los jóvenes buscan otros espacios no participados por sus padres o abuelos, y más cercanos a sus intereses. 
En el quinto capítulo, Enrique Iturralde Chaparro, de la Universidad Nacional Autónoma de México (México), investiga las prácticas participativas de un grupo de discusión sobre Historia en Facebook, mediante un enfoque etnográfico. En concreto, el investigador se convirtió en un observador participante, complementada dicha tarea con un análisis de contenido para evaluar las tendencias internas detectadas. A través de este trazado metodológico, el autor describe los contenidos que tienden a publicarse en ese enclave, así como identifica algunas actitudes clave para entender la interacción desde este tipo de espacios en línea. Dentro de los resultados, se indica que las publicaciones con más interacciones estuvieron relacionadas con el hating, seguidas de aquellas interpretadas como trolling. En las conclusiones, el autor subraya que los ataques entre usuarios son una forma espontánea de manifestar determinadas emociones, los cuales contribuyen con la construcción de la identidad en línea de los usuarios.

En el sexto capítulo, Sergio Rivera Magos (Universidad Autónoma de Querétaro, México), y Bruno Carriço Reis (Universidade Autónoma de Lisboa, Portugal), analizan las prácticas en línea de los jóvenes de Querétaro, en México, con el objetivo de evaluar los comportamientos de riesgo a los que posiblemente se enfrentan. Algunos de estos riesgos son, por ejemplo, la gestión de la intimidad, con la posibilidad de revelar datos sobre la vida privada de los adolescentes (y los efectos que puede derivarse de esta problemática); las adicciones; los acosos; las amenazas derivadas de la seguridad informática, entre otros. En ese sentido, en este trabajo se aplicó una encuesta a 600 estudiantes de enseñanza media queretanos. Los resultados obtenidos permiten a los autores asegurar la existencia de prácticas de riesgo, por lo que aconsejan la sensibilización de este grupo poblacional encuestado, así como ampliar las políticas públicas para dar cabida a estos nuevos desafíos.

En el séptimo capítulo, Malvina Eugenia Rodríguez (Universidad Nacional de Villa María, Argentina), se centra en las comunidades sociodigitales argentinas, esto es, esos espacios de participación enclavados en línea. En este trabajo, y mediante la observación de plataformas como La Tinta, la autora reflexiona sobre el ciberactivismo que emerge a partir de estas soluciones colectivas. Pero a pesar de su 
creciente consolidación social, finalmente, en este último capítulo la autora se plantea cuál es el impacto que tienen estas comunidades en el espacio fuera de línea, una interesante interrogación con la que se cierra este libro.

Como puede deducirse de la síntesis mostrada anteriormente, este texto, producto de los trabajos permanentes de reflexión del Grupo temático 19 Comunicación digital, redes y procesos de la Asociación Latinoamericana de Investigadores en Comunicación (ALAIC), pretende sumar a la construcción relacional sobre las juventudes mediatizadas, que nos permiten explorar desde el hetero y media reconocimiento nuevas formas de entender las nociones de clase, etnia, género, interconexión, participación y socialización.

Lo joven es una metáfora del cambio social, de los movimientos sociales, de las articulaciones, negociaciones y prácticas simbólicas y culturales.

Entender la hipermodernidad implica comprender la cultura popular, los cambios tecnológicos y mediáticos y, sin duda, lo juvenil. Y es en esa arista de discusión donde pretende contribuir el libro que hoy tienen en sus manos. ¡Que siga la reflexión! 



\title{
Jóvenes hipermediales: hipermediatización del Yo y las juventudes hiperconectadas
}

\author{
Jorge Alberto Hidalgo Toledo \\ Universidad Anáhuac (México) \\ jhidalgo@anahuac.mx
}

PARA CITAR: Hidalgo Toledo, J. (2019). "Jóvenes hipermediales: hipermediatización del Yo y las juventudes hiperconectadas". En Barredo Ibáñez, D.; Cunha, M. R. \& Hidalgo Toledo, J. (Eds.) (2019). Jóvenes, participación y medios de comunicación digitales en América Latina <pp. 17-45>. La Laguna, España: Cuadernos Artesanos de Comunicación. DOI:

\section{Resumen}

Los medios se han vuelto omnipresentes, se han extendido por todos los rincones y momentos de la vida. Las personas han establecido fuertes vínculos con ellos, configurando relaciones personales y grupales. Los medios se han vuelto un territorio, un escenario más en el que necesitan presentar su yo a los demás. En los medios, los jóvenes conectan sus ideales, motivaciones e intereses. En los medios se están estableciendo nuevas marcas territoriales y resistencias. Los medios han superado en su distribución y poder, las fronteras supranacionales y por ende, la lógica del Estado Nación. La emergencia global de medios e hipermedios en los que se crea, colecta, procesa, almacena, administra y comercializa información es un fenómeno que se extiende en todos los niveles y fases de la vida. La vida corriente se ha vuelto una vida mediada, en que los sujetos proyectan y miden sus influencias mediáticas como lo hiciera un líder de opinión. 


\title{
Palabras clave
}

Internet, Sociedad de la información, Culturas juveniles digitales, Identidad hipermedial, Alfabetización Transmedia.

\begin{abstract}
"Mis hijos y sus amigos (adolescentes todos) utilizan los medios para informarse

(no consultan enciclopedias en papel nunca), hacer la tarea, ponerse de acuerdo con los compañeros (ya no llaman por teléfono, todo es vía Skype, Facebook, Whatsapp), juegan en solitario o en partidas online, piden permiso, ven películas o series, escuchan música, estudian, hacen exámenes rápidos, el mayor platica con la novia, socializan, toman notas, en lugar de copiar la información, toman una foto.

No conciben el mundo sin internet, computadoras, televisión, celulares, en términos de que no imaginan cómo era vivir sin eso"
\end{abstract}

(Sujeto Informante Digital, SID1, Querétaro, Querétaro, México ${ }^{1}$ ).

\section{Introducción. Jóvenes y plataformas hipermediales}

T OY ante la multiplicidad de medios y nuevas plataformas hipermediales y tras el fenómeno de fragmentación de audiencias que se vive en el interior de la industria mediática, se hace notorio conocer, por un lado, los usos, consumos y apropiaciones de tecnologías de información y comunicación; y por otro, los intereses, necesidades, deseos y percepciones de las audiencias para dar cuenta, con todo ello, las vías que tienen las personas para proyectar su yo en el mundo hipermedial.

Los medios e hipermedios han tenido que adaptarse a la exigencia de un público más complejo, selectivo y exigente que encuentra más formas de evitar los contenidos publicitarios y que demanda formas novedosas de tomar el control y dejar de lado la experiencia pasiva, unidireccional y poco interactiva (Livingstone, 2009).

\footnotetext{
${ }^{1}$ A partir de este momento el lector encontrará la referencia SID como acrónimo de Sujeto Informante Digital; es decir, las personas que contribuyeron al estudio cualitativo a través de entrevistas, foros de discusión y sesiones en línea de metareflexión sobre la condición de juventud y vida digital.
} 
Los medios han dejado de ser pequeñas empresas para convertirse en los sectores industriales que mayor beneficio económico y empleo generan en algunos países (Martel, 2011). Han pasado a ser uno de los principales bienes de socialización de la sociedad moderna. Sus recursos simbólicos y el capital experiencial que generan, promueve actitudes y formas de conducta que aportan valor (positivo y negativo) a la sociedad (Tapscott, 2000).

Por tanto, ¿quiénes son los receptores de medios e hipermedios en México? ¿Qué tanto se conocen los hábitos y motivaciones mediáticas de dichos usuarios? ¿A qué tipo de contenidos están expuestos? ¿En qué forma han cambiado los usos, consumos y apropiaciones de medios en la población juvenil con la incursión de las tecnologías de información? ¿Qué uso hacen de las experiencias mediáticas los consumidores?

Niños y jóvenes constituyen el epicentro de la cultura del consumo y del consumo mediático de México y la mayor parte del mundo. Capitalizar su atención y sus opiniones es parte de la estrategia de los artífices de la cultura (Schor, 2006). Este segmento poblacional se ha convertido en un eslabón entre los contenidos mediáticos y sus familias. Su mundo social se construye desde la dimensión del consumo; la agenda de su día a día se empieza a definir desde los medios con los que se relacionan e involucran. Su identidad es moldeada en gran medida por la forma como socializan sus experiencias mediáticas.

¿Qué uso hacen de las experiencias mediáticas los consumidores? Es un hecho, como señala Sonia Livingstone (1990) que las interacciones parasociales en las que están inmersos los usuarios de los medios e hipermedios no se dan como identificaciones pasivas sino como si estuvieran relacionándose con situaciones, voces y actores reales entremezclando lo experimentado con su propia historia.

Los medios se han convertido en un laboratorio para la construcción de identidad. La identidad de las personas y su personalidad son producto de la interacción de su historia particular; su ambiente social 
y cultural; sus experiencias y encuentros personales; y su interacción mediática e hipermediática (Livingstone, Holden, \& Bovill, 1999).

Roger Silverstone en su texto ¿Por qué estudiar los medios? (2004) deja ver cómo hoy los medios están en el centro de la experiencia y en el corazón de nuestra capacidad o incapacidad para encontrarle un sentido al mundo en que vivimos. No sólo son el pasatiempo más importante sino el más significativo en la vida de las personas. Su importancia permea las esferas económicas, sociales y culturales.

\section{Juventud en el espacio mediático}

Juventud, más allá de la dimensión biológica, psicológica y social, es una construcción social que ha pasado de la ubicación de una fase particular en un ciclo de vida, en un tiempo y un espacio a una construcción relacional, una variable del análisis social y la unidad básica de las culturas juveniles (Urteaga Castro-Pozo, 2010). La emergencia del joven en el campo social y académico se hace visible desde la segunda mitad del siglo XX por su protagonismo en el espacio público, social, político, económico, cultural, artístico, estético, discursivo, mediático y tecnológico. Desde los movimientos beat, hippies, estudiantiles, la onda, punks, yuppies, trashers, ciberpunks, grunge, skatos, darketos, emos, góticos, technos, tribales, las tribus del pulgar y el arribo de las múltiples generaciones Baby boomer, Gen X, Gen Net, Gen Media, Tweens, Gen Transmedia, Gen Hastag los jóvenes ocuparon el espacio popular urbano, con los años se han construido cartografías que dan cuenta de este nuevo estrato en la modernidad capitalista donde las culturas juveniles, sus prácticas, formas de autorreconocimiento y heterorreconocimiento se adscriben fielmente a formas particulares de consumo.

Las expresiones juveniles que accedieron al espacio público en la segunda mitad del siglo pasado han sido revisadas en sus lógicas, afanes, preguntas, actancias, identidades diferenciadas y diferenciables. Los jóvenes, en tanto categoría sociocultural, son un producto de la posguerra (Reguillo, 2010). Las dimensiones de estudio, por la inserción del joven en el campo social, contemplan a los conectados y desconectados, a la que podríamos añadir los mediatizados. 
Los actores juveniles se están, permanentemente estructurando y reconfigurando a través de sus prácticas sociales y culturales, sus representaciones sociales, sus realidades, adscripciones y apropiaciones. La condición juvenil se da en el entrecruce de las categorías de clase, etnia y género en los niveles microsocial, relacional y estructural y la interconexión o imbricación de sus zonas fronterizas o transfronterizas (Urteaga Castro-Pozo, 2010). Las juventudes, conectadas, desconcetadas y mediatizadas (Reguillo, 2007) poseen distintos capitales (Reguillo, 2010)a los que pueden acceder, poseer, usar, acumular (Ilustración 1): objetivo, cognitivo-escolar, social, político, cultural y simbólico. La juventud se ha inscrito como una nueva clase, como una cultura y una subcultura, de ahí que posee una triple articulación con las culturas parentales, la dominante y sus grupos de pares. Lo joven es una metáfora del cambio social, de la movilización, de la negociación, de las nuevas prácticas culturales, estéticas y simbólicas. La apropiación simbólica de sus espacios y territorios habla de nuevos itinerarios y rutas significativas, de espacios legitimados y otros paralelos. Lo joven hoy moviliza las dimensiones culturales, sociales, económicas, políticas, mediáticas y tecnológicas. Distinguir los estilos de vida jóvenes permite hablar de las prácticas de consumo, la inserción en la dinámica global, la integración/incorporación a las instituciones o la marginalidad.

\section{Ilustración 1. Categorías de juventud}

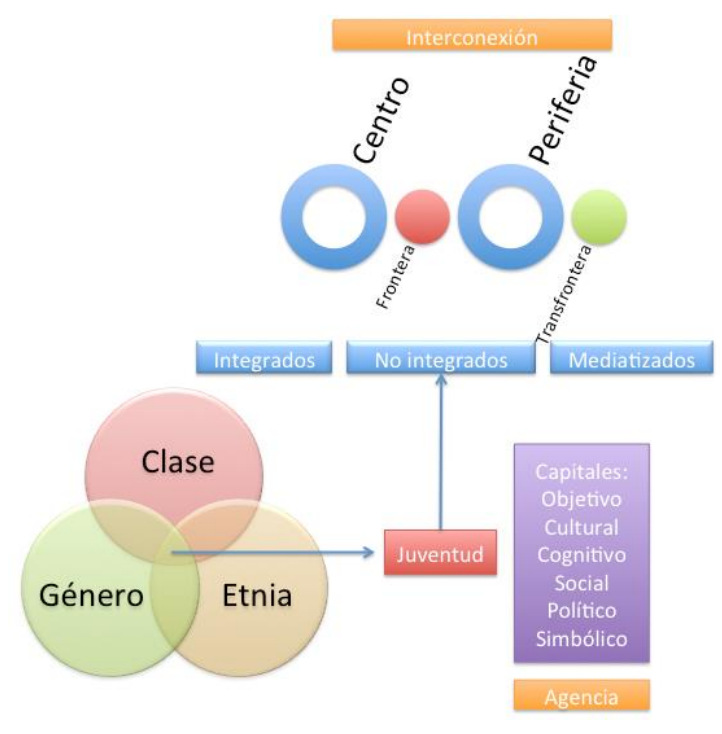

Fuente: elaboración propia basada en (Gómez Vargas, 2008);

(Urteaga Castro-Pozo, 2010); (Reguillo, 2010) 
Captar teórica y metodológicamente los cambios y distinciones del fenómeno juvenil es la pretensión de este trabajo dando cuenta del espacio social juvenil, su estructuración y articulación con la apropiación de medios e hipermedios considerando el impacto que éstos tienen en la configuración de la identidad de los jóvenes. Desde la perspectiva de lo juvenil, sus campos, subcampos, agentes, espacios, prácticas, distinciones, gustos, significaciones, actitudes, ideales se contemplan las apropiaciones del mercado, el espacio urbano, la industria del entretenimiento y las nuevas tecnologías pues como señala Maritza Urteaga (2011, p. 34):

"Dentro del espacio social juvenil, los medios y las nuevas tecnologías no son simplemente mercancías simbólicas o marcadores de distinción, sino redes cruciales en la definición y distribución del conocimiento cultural. La diferencia entre estar dentro (in) o fuera (out) de la moda, alto o bajo en capital subcultural, se correlaciona de maneras complejas con grados de información, creación y exposición a los mismos".

\section{Los medios como espacio social juvenil}

"Muchos jóvenes no están en contacto con medios e hipermedios. De los que sí lo están creo que hay una correlación entre múltiples variables históricas, políticas, culturales, económicas, tanto del entorno como del sujeto que configuran las prácticas sociales, los imaginarios y las representaciones que tienen los jóvenes en relación a los medios e hipermedios. Lo que sí me queda claro es que el mercado se preocupa por hacer creer una serie de discursos que hacen que algunos sujetos piensen que el papel de los medios ES de determinada manera y luego vienen los contradiscursos y la resistencia y las otras realidades... para mí es un tema complejo en donde es muy difícil generalizar". (Entrevista a Expertos, EaE2, México, DF, México)

Desde sus orígenes los medios han jugado un papel fundamental en vida de las personas y en la historia misma de la humanidad. La pintura y la escritura permitieron extender la memoria del hombre; como soporte, resguardaron las historias, los procesos y las estructuras sociales. La iconografía, se obsesionó por la representación, la 
emulación y reproducción de la realidad con la intensión de ser espejo y refracción del mundo, sus misterios y sacralidad. Mientras las imágenes apelaron a su condición referencial e índex, la escritura allanó la abstracción, los imaginarios; intentó con todo atrapar el pensamiento.

La imprenta permitió la masificación del conocimiento, la reproducción de las ideas y la inmersión de cada sujeto en las historias narradas por otros y amplificar los significados y la interpretación. La fotografía, como la pintura, atrapó la realidad; congeló los momentos; democratizó la memoria social, registró al individuo y lo ubicó en un lugar en el mundo; fraccionó el instante; hizo del mundo un fragmento; piezas para armar.

El cine materializó las emociones y convirtió en imágenes la ilusión. Al igual que el libro, dio una estructura a las narrativas. Permitió la existencia de mundos y realidades paralelas; volvió la vida en una representación de si misma; instituyó un imperio vicario, permitiendo la inmersión en vidas y microcosmos que sólo existen en el contenido creado y en la imaginación de los creadores y en los procesos de descodificación de los receptores.

La radio compactó la voz y amplificó su alcance; acercó las historias y mensajes a todos los rincones del mundo. Al hombre y al mundo los tornó en frecuencias, sonidos, vocablos, representaciones sonoras. La radio fue la síntesis de la apuesta del hombre por la exploración de la realidad más allá de su materialidad. La radio era la apuesta concreta por la reconstrucción de la realidad en el espacio mental.

La televisión, el imperio de la imagen, apostó por la captura instantánea, seriada, en movimiento y global de la realidad. Como la radio, acercó a los hombres, permitió visualizar tiempos, espacios, lugares y vidas entre sí. Los medios, poco a poco se incorporaron a la vida de los sujetos, se convirtieron en testigos de todo: del mundo físico, del imaginario y el simbólico. Pasaron del espacio público al privado; del contexto masivo al individual. Hoy los medios dejaron de ser el canal por el cual se transmite información, cultura y entretenimiento. Los medios se han convertido en el puente de significación por el cual circulan los macro y los ego discursos. Los medios 
son el hardware y el software en el que se explora, navega, profundiza y comprende por entero la realidad. Los medios son máquinas, escenarios, prácticas, actividades, redes, estructuras, organismos, territorios en los cuales, las personas y las instituciones: 1) amplifican sus ideas, experiencias y expresiones; 2) confrontan al mundo y a los otros; 3) orientan sus visiones, percepciones, prácticas y sentires; 4) incluyen o excluyen personas, lugares ideas o situaciones.

Los medios han saturado todos los espacios de la vida envolviendo a las personas en su condición dual de instrumentos de mediación y de elementos constitutivos de la experiencia humana comunicativa.

En ese contexto en que los medios se han convertido en formas vivientes de las prácticas humanas y en extensiones del hombre (al más puro estilo de McLuhan), las personas han extendido también sus prácticas identitarias a través de ellos. La vida se ha vuelto un complejo conversatorio, un flujo continuo de códigos, lenguajes y narraciones; en un territorio de significación permanentemente en construcción en el que los individuos no sólo captan mensajes, sino que también en ellos resignifican la vida.

Los medios pasaron de ser vehículos y canales para ser parte del estilo de vida o el lugar donde se configuran los mismos. Persona, espacio, lugar cohabitan en el lenguaje y como código que son, se convirtieron en material simbólico de consumo. Hay vida en, con y desde los medios. Los medios conectaron al mundo y cuestionaron la condición material del hombre y la vida; los límites de nuestra fragilidad circulan hoy como contenidos fragmentados y atomizados por todo el mundo.

En el corazón del clímax de la evolución de los medios tradicionales, las audiencias se fueron apoderando y empoderando de ellos. Las familias, por completo, les permitieron juzgar un rol determinante en sus vidas. Alrededor de ellos, construyeron sus nuevas prácticas sociales; modificaron sus dinámicas vitales tomando como referencias cardinales los sucesos que ahí se narraban y socializaban. La vida se empezó a tornar con ello en un contexto comunicativo, en una forma de interacción y conexión con la hipercomplejidad de la vida postmoderna. Esta dinámica global de sobrevivencia simbólica que nos 
permitió a todos ser observadores y testigos, rearticuló la vida social. La realidad se mediatizó, las experiencias y significados de la vida se anclaron a los sistemas de codificación y descodificación de los medios. El espacio donde se construye, vive y comprende nuestra humanidad son los medios. La interacción permanente con esa imaginaria conexión y significación nos moldea y afecta, por ende, nuestro lugar en el mundo y nuestros modos de conocerlos y comprenderlo.

Fue singular cómo en la década de los cincuenta del siglo pasado se detonó ante el periodo de aparente abundancia de la postguerra una marcada cultura juvenil. En ese momento histórico nacen los denominados teen media: cine, radio, televisión, cómics y revistas. Poco a poco las jóvenes audiencias empezaron a consumir dichos medios en todos los momentos, tiempos, lugares y contextos. Fue tal el papel que desempeñaron que se convirtieron en el pasatiempo más significativo en sus vidas. Hoy los medios son el principal recurso de expresión y comunicación de las culturas juveniles, al grado de que en la década de los ochenta empezaron a agruparles sociológicamente como la Mtv Generation, la Generación Click, la Generación Net, la Generación Mediática, la Generación Nintendo, la Generación Txt, la Generación Mi Medio, Generación Hashtag hasta hoy que nos encontramos frente a la Generación Transmedial.

Los medios ha ocupado un lugar tan importante en la vida de los jóvenes que han llegado a sustituir el liderazgo moral que ejercían las instituciones base como la familia, la escuela y la iglesia. Hoy los medios se han vuelto omnipresentes e inevitables para establecer procesos de comunicación, interacción y socialización. Los medios han dotado de contenidos, texturas, rutinas e interpretaciones la vida de niños y adolescentes. Con y desde ellos, retoman recursos simbólicos para comprender la vida y la cultura; se han colocado en el centro de sus vidas que es con ellos que le encuentran un sentido al día a día. El espacio mediático se ha convertido en el espacio social juvenil.

\section{Las Generaciones Mediáticas}

Hace poco más de veinte años los medios de comunicación masiva dieron un giro radical a la cultura y sus aproximaciones hipermediales. 
El nacimiento de la cadena musical $M T V$ había gestado una generación de usuarios que tenderían a ver el mundo como un videoclip: edición rápida, historias paralelas, pensamiento no lineal, alteración del contexto visual por sobre información, la conjunción de discursos: visuales, auditivos y narrativos y yuxtaposición de texturas y colores. A partir de ahí, los jóvenes consumidores de medios no volvieron a ser los mismos. Una nueva sintaxis estaba definiendo la estructura gramatical del consumo mediático.

Posteriormente, se categorizó a la Generación click, altamente familiarizada con el discurso mediático establecido por las computadoras personales, el nacimiento de la nueva carne en que la máquina y su inteligencia artificial, intentan ser una reproducción a imagen y semejanza del hombre; la Generación Red que nació y creció empapada de la lengua de Internet deseosa de hacer extensiva la naturaleza del hombre al entorno global; y, la Generación $M$ presentada por Donald Roberts en el año 2005 en el estudio realizado para la Kaiser Family Foundation llamado Generation M: Media in the lives of 818 year-olds. Esta Generación altamente mediatizada, en línea y medianamente tolerante a los contenidos publicitarios dio paso al registro de My Media Generation; jóvenes entre los 13 y los 24 años que nacieron y crecieron con los medios interactivos e inalámbricos. Esta Generación, evolución de la reportada por Roberts, posee un gran número de medios portátiles propios; adoptaron como suyas las tecnologías de información móvil e Internet; usan los medios tradicionales únicamente para saber de moda, belleza, celebridades, actitudes a imitar; son multitasking y están altamente acostumbrados al engranaje mediático publicitario (Hidalgo Toledo, 2007).

Nuevas industrias, nuevas tecnologías de información, nuevos medios, nuevos consumos, nuevas generaciones, nuevos usos... Videos, dispositivos electrónicos, televisión y radio satelital, computadoras personales, Internet, son parte de las transformaciones que han afectado cualquier aspecto de lo que hoy se hace. Hoy, los mercados globales, la economía digital, el dinero electrónico, la comunicación instantánea y electrónica, las transmisiones satelitales se entrelazan como un grito para confrontar el silencio eterno y celebrar la mundialidad. Pensar la globalización lleva, como apunta Anthony 
Giddens (2005) en un ver lo de afuera, para sumergirse en lo de adentro; en un contemplar la transformación que se vive en el interior de los sistemas familiares, los valores humanos y las afectaciones directas e indirectas en la persona humana. Las presiones hacia arriba y hacia abajo confrontan las identidades. Fluyen nuevas voces ideológicas desde el corazón mismo de las industrias culturales. Una nueva conquista se está llevando a cabo: la conquista de las identidades.

Considerando esta evolución de las diversas generaciones digitales, la contribución considerada estará en dos ámbitos: la reflexión y descripción de las múltiples identidades hipermediales derivadas de la interacción digital; así como desde la construcción de una taxonomía de las competencias y mediaciones digitales.

\section{Uso, consumo y apropiación de medios e hipermedios}

Como primera fase del sistema de apropiación es importante comprender la noción de "uso". La acepción de uso planteada en el presente texto remite al carácter instrumental del medio. A la distancia material y funcional que establece el individuo con el medio. A una condición que se materializa por el modo: objetual, reflexivo, estructural, de mediación, de gratificación y cumplimiento de finalidad en tono pasivo del medio y las audiencias. El uso nos remite al cortejo del mercado con el sistema sensorial y la satisfacción de todo placer. Placer por tener, manipular y significar. Usar remite necesariamente a funciones rituales, sociales y externalidades de decisión (presión por incertidumbre), de información (presión en busca de consejo), coercitiva (presión de pares), de mercado (presión en busca de rendimiento creciente) y de coordinación (presión por grado de cooperación). Los medios son ese territorio común donde a través del uso, el hombre se descubre y se proyecta; conoce al mundo y lo comprende; da cuenta de lo que es capaz.

Sintetizando las tradiciones reflexivas de la comunicación encapsuladas en estas categorías conceptuales podríamos definir el indicador de "uso mediático" como: la orientación objetual y funcional de los medios como difusores y mensajeros de contenidos, productos e ideologías con gran capacidad de reflejar la condición social y sustituir la realidad al ser parte de una estructura de poder que 
bajo la premisa de cumplir un fin social satisface necesidades básicas de información y significación en cada receptor.

Por tanto, se puede decir que el "uso" es una distancia funcional que remite a la condición pasiva del usuario que obtiene una gratificación cuando el medio cumple una finalidad concreta y empática con sus necesidades. El consumo es casi un "ciclo metabólico" como lo plantea Bauman. Las actividades relacionadas con este (producción, almacenamiento, distribución y eliminación) reflejan el estilo y sabor de la vida social; por tanto, termina canonizando el querer, desear y anhelar. El consumo, tras la revolución consumista, se ha tornado en el propósito mismo de la existencia y el fundamento de la economía de las relaciones humanas (Bauman, 2010; Bauman, 2009, p. 44)2. Toda persona construye, desde el consumo, un relato de su experiencia existencial y la comparte, la intercambia, como quien mercantiliza bienes.

Consumo y consumismo no es lo mismo. Sus acepciones responden al paso de la sociedad de productores a la de consumidores. Mientras el consumo es un rasgo y una ocupación del individuo, el consumismo es un atributo de la sociedad. El mismo Bauman lo acota al señalar que: "el consumismo es un tipo de acuerdo social que resulta de la reconversión de los deseos, ganas o anhelos humanos en la principal fuerza de impulso y de operaciones de la sociedad, una fuerza que coordina la reproducción sistemática, la integración social, la estratificación social y la formación del individuo humano, así como también desempeña un papel preponderante en los procesos individuales y grupales de autoidentificación, y en la selección y consecución de políticas de vida individuales" (Bauman, 2009, pág. 47).

La clave diferenciadora entre el consumo y la apropiación son las motivaciones. El consumo es deseo, posesión y acumulación. La apropiación responde a condiciones identitarias. Las personas,

\footnotetext{
${ }^{2}$ Ciclo que va de la ingesta a la excreción pasando por la digestión y que habla de una función imprescindible para la supervivencia biológica; por tanto, es una condición permanente, inamovible, inalienable y continua.
} 
construyen estrategias de vida y sus patrones de comportamiento y consumo buscan dar cuenta de esa identidad creada.

La apropiación se establece cuando el receptor acorta la distancia con los medios, objetos, productos y servicios y los hace suyos; por ende, hay que leer la apropiación desde las motivaciones, las aspiraciones y evocaciones de cada sujeto, comprendiendo aquello que le da seguridad, confianza, orden, normas y poder. En un contexto en que el consumo se rige por la "obsolescencia incorporada", los deseos inestables y la insaciabilidad de necesidades (Bauman, 2009, p. 51), las audiencias se apropian de los significados renegociados y los incorporan en el ciclo de la identidad. En un entorno discontinuo y fragmentado, aquello de lo que se apropian intenta dar cuenta de una identidad estructurada e integrada. Apropiarse permite configurar comunidades de significación y pertenencia. La identidad, por ende, es el gran indicador de la vida hipermoderna.

\section{Los hipermedios como principal recurso simbólico y experiencial}

¿Por qué esta búsqueda en particular? Como se señaló anteriormente, a lo largo de las investigaciones sobre consumo de medios se ha visto: 1) que hoy las jóvenes audiencias pasan más tiempo consumiendo medios de comunicación que en la escuela o conviviendo con la familias (Silverstone, 1994); 2) que los medios se han constituido en el pasatiempo más significativo del tiempo libre de niños y adolescentes (Watkins, 2009); 3) que los medios son el principal recurso contemporáneo de expresión y comunicación cultural (Buckingham, 2005); 4) que quien desea participar activamente en la vida pública usa los medios e hipermedios para amplificar su impacto de modo rápido y profundo en la cultura (Umaschi Bers, 2008); 5) que los medios están sustituyendo el liderazgo moral que tenía instituciones como la familia, la iglesia y la escuela (Schor, 2006); 6) que los medios están cobrando una posición de omnipresencia y son inevitables en los procesos de comunicación, interacción y socialización entre niños y adolescentes (David, 1999); 7) que los medios impregnan texturas y rutinas de la vida cotidiana y la cultura (Poniewozik, 2005); 8) que proporcionan recursos simbólicos usados para distinguir e interpretar relaciones y definir 
identidades (Buckingham, 2008); 9) que los medios están en el centro de la experiencia y en el corazón de nuestra capacidad e incapacidad para encontrarle un sentido al mundo en que vivimos (Silverstone, 2004); y 10) que muchos medios promueven actitudes o formas de conducta indeseables de tipo violentas, sexistas y racistas estableciendo discursos empáticos con las jóvenes audiencias (Daniels, 2008); 11) los jóvenes se han hecho visibles a través de los medios, sus representaciones, prácticas y estéticas. El espacio social juveniß (Urteaga Castro-Pozo, 2010), se construye en el siglo XXI en gran medida desde el espacio mediático.

Los estudios sobre consumo de medios y niños y jóvenes han sido abordados desde: los derechos de los niños y los jóvenes, la violencia mediática, las identidades juveniles, la cultura de los fans, el empoderamiento mediático, la educación para los medios, las nuevas audiencias y las audiencias digitales y la alfabetización digital y las multiconvergencias mediáticas. Este texto en particular, pretende entender el entre cruce entre consumo cultural, consumo de medios y cultura juvenil. Ya que es en esa convergencia donde se da la configuración de la identidad (Ilustración 2).

A diferencia de los estudios anteriores, se pretenden estudiar las prácticas, expresiones y producciones de sentido desde lo urbano, lo mediático e hipermediatico y la corporeidad en el terreno de lo hipermedial. Por lo anterior en el presente texto se tomarán como referencia teórica los estudios de consumo cultural, mediáticos y de recepción; el abordaje teórico contempla elementos propios de la teoría de la recepción, los estudios culturales, las generaciones mediáticas y los estudios de identidad; así como la economía política de los medios globales.

\footnotetext{
${ }^{3}$ Como recorte del campo del mundo social planteado por Bourdieu como espacio social. Es conceptualizado por Maritza Urteaga, como "la base de principios de diferenciación o distribución constituido por el conjunto de propiedades que actúan en el universo social en cuestión, es decir propiedades capaces de conferir a quien las posea con fuerza, poder, en ese universo" (Urteaga Castro-Pozo, 2010, p. 32).
} 


\section{Ilustración 2. Dimensiones de los estudios de consumo de medios y jóvenes}

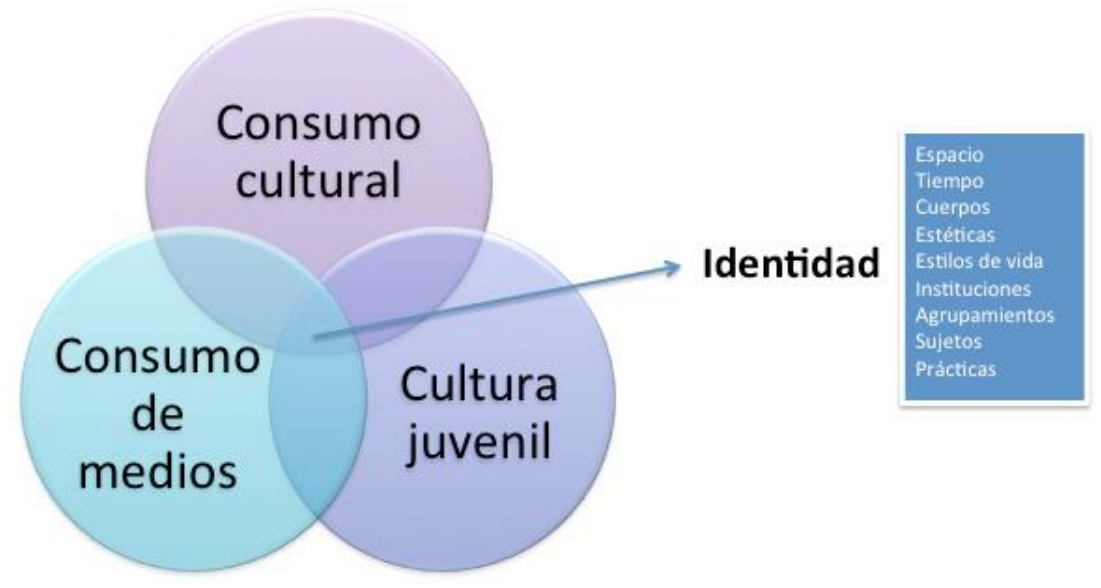

Fuente: elaboración propia basada en Gómez Vargas (2008)

\section{La nueva cultura digital y los súper usuarios mediáticos}

Como señala Roxana Morduchowicz (2008), hoy la cultura popular es entendida por los jóvenes como la cultura audiovisual y mediática. En la intersección entre el texto escrito, la imagen electrónica, la digitalización de contenidos y la cultura popular se construyen nuevas formas de percibir, sentir, escuchar, ver, dialogar, socializar, entender, nombrar, explorar y definir la propia existencia. Siendo los medios e hipermedios los que aportan elementos clave para dar sentido a la identidad de los jóvenes.

Sin lugar a dudas, los jóvenes son cada vez más súper usuarios de los medios que consumen. La interacción con nuevos dispositivos y tecnologías de información y comunicación satisface su curiosidad y en cierta medida, estimula las necesidades intelectuales de unos tantos. No obstante, hacer de cada "lector" un "autor" implica un proceso que va más allá de la simple interacción de los jóvenes con los medios. Las nuevas formas de recepción y las grandes transformaciones hipermediáticas obligan a establecer un diagnóstico profundo para identificar la manera en que la interacción jóvenes-medios-hipermedios impacta en la construcción de la identidad. 
La comprensión de los nuevos usos, consumos y apropiaciones conlleva algo más que conocer los nuevos contextos mediáticos, de recepción y de las nuevas prácticas comunicativas; asimismo implica un análisis de la influencia de los medios e hipermedios en la cultura popular, en los contextos sociales y familiares y en la identidad de los mismos jóvenes. Por ende, este texto pretende aportar nuevos enfoques teóricos para entender a las generaciones mediáticas, así como los desafíos alfabetización transmedial para que resulte de dicha interacción una producción comunicativa plena de sentido.

\section{La hiperconexión de la Generación Mi Medio}

Hoy, la principal motivación de la Generación $M i$ Medio $^{4}$ es la hiperconexión; el mantener la existencia permanentemente en línea; el autodescubrirse y autodesarrollarse en la interacción on-line con los otros. Las grandes tribus telefónicas movilizan su espacio de comunicación privada; se comunican fuera del ámbito controlado por los padres; intiman desde cualquier punto; se expresan a través de múltiples narrativas y desde cualquier lugar. La vida entera se construye en la marcha; y en movimiento se expresan odios, se prueban los límites, manifiestan deseos y se actúa como intermediarios.

La vida móvil, la vida en línea, la vida portátil permite la vinculación omnisciente; permite estar siempre ahí, compartir la vida en tiempo real; permite expresar de un modo poco análogo el "pienso en ti". La hiperconexión es el mensaje. Es un modo de consolidar la colectividad; de socializar la identidad; de expandir el compromiso y la lealtad.

Estar siempre disponible en ese pequeño "rincón del mundo"-hoy primer universo para la Generación My Social Media- los hace sentir en casa, en un mundo donde los sin techo son los que se han quedado fuera de la aldea digital. Como se puede ver, las personas, tienen la capacidad de interpretar, comprender, entender y disfrutar, los contenidos de todos los medios de comunicación. Pero una simple lectura de los "textos mediáticos" no basta, es importante agudizar dicha habilidad a

\footnotetext{
${ }^{4}$ Nombre con el cual bautizaron Yahoo! y su agencia de investigación de mercados OMD, en el año 2005, a la generación de usuarios tecnológicos altamente comprometidos con los medios de comunicación, particularmente los hipermedios.
} 
través de un filtro crítico para convertir a las audiencias en algo más que espectadores pasivos de los medios.

Los medios e hipermedios cada día se incorporan y adaptan en mayor profundidad a los valores, tradiciones, necesidades y emociones de las personas. Se han convertido en agentes transformadores de la cultura. Hoy los usuarios de la comunicación cambian sus estilos de vida tan rápido como cambian de gustos. Su condición de prosumidores ${ }^{5}$ está transformando el paradigma con el que establecían los contenidos de los medios y las planeaciones estratégicas al interior de las agencias de mercadotecnia y publicidad.

La tendencia actual implica: 1) la personalización de interfaces, dispositivos, mensajes y productos; 2) la satisfacción no de necesidades sino deseos; 3) intimar con las audiencias y estableciendo compromisos de confianza; 4) apelar a la visibilidad, notoriedad y las aspiraciones; 5) generar mensajes carismáticos que provoquen respuestas emocionales; 6) aportar soluciones humanas basadas en la innovación y la experiencia sensorial; 7) establecer una conexión sólida y permanente con la gente; 8) compartir y promover el diálogo entre la marca, el mensaje y la audiencia; en pocas palabras, vender y consumir. Para los dueños de los medios y sus mercadólogos, conocer las características de sus consumidores y de su entorno permite modificar las tendencias de compra y venta de productos, servicios o marcas.

En México, como en gran parte del mundo se está viviendo un gran cambio en los estándares de uso y consumo mediático. Cifras publicadas por el estudio 14 Estudio sobre los Hábitos de los usuarios de Internet en México 2018 (2018) reportan la existencia de 79.1 millones de internautas que representan el $67.7 \%$ de penetración nacional en personas mayores de 6 años. El crecimiento en el uso de teléfonos inteligentes con acceso a Internet ha sido exponencial hoy representa el 76\% de las conexiones versus el 66\% de una laptop. Es importante saber que el $86 \%$ de las personas ingresan desde sus hogares, $6 \%$ desde

\footnotetext{
${ }^{5}$ Palabra compuesta de la fusión de las palabras Productor-Consumidor. Se le atribuye a McLuhan el concepto y aparece mencionado en el libro la Tercera Ola de Alvin Toffler. Comprende la visión del sujeto como totalidad del modelo de comunicación: emisor, medio, canal, ruido y receptor a su vez.
} 
un café internet, $49 \%$ desde sus trabajos, $13 \%$ desde su lugar de estudio y $68 \%$ desde un lugar público. $51 \%$ de los internautas son hombres y $48 \%$ del total de usuarios pertenecen a los niveles $\mathrm{ABC}+{ }^{6}$. La composición de edad del universo de usuarios registra un 34\% de los jóvenes mexicanos entre los 6 y los 17 años de edad.

En función del presente texto, la composición del universo de internautas por edad destaca lo siguiente: $18 \%$ entre los 12 y 17 años; $17 \%$ entre los 18 y $24 ; 19 \%$ entre los 25 y 34\%. Así se tiene que 35\% de los jóvenes mexicanos entre los 12 y 24 años están en Internet; viviendo el 23\% en el Centro Sur del país. Las actividades realizadas en línea oscilan entre 89\% Acceder a Redes Sociales, 84\% enviar y recibir mails; $83 \%$ chatear; $82 \%$ buscar información, 73\% Utilizar mapas; 68\% escuchar música; 65\% leer, ver y escuchar contenidos relevantes; 65\% ver películas en streaming; $43 \%$ estudiar en línea; $43 \%$ hacer videollamadas; $31 \%$ jugar en línea.

En promedio los navegantes invierten 8 horas 11 minutos para consultar información de lunes a viernes conectándose en promedio entre 2 y 3 veces por semana. Sus principales actividades son: ocio $53 \%$; finanzas $46 \%$; formación: $41 \%$; trámites $41 \%$; compras 39\%; contactos $21 \%$.

En México existen 66,761,063 personas que van de los 0 a los 34 años de edad, 51\% mujeres y 49\% hombres (Tabla 2); todos ellos, base de la pirámide poblacional y mayormente expuesta al consumo de medios (Instituto Nacional de Estadística y Geografía, 2005). De dicha población se tiene que poco más de 40 millones se ubican en la minoría de edad y poco más de 30 millones de ellos menores a los 15 años. En un lapso de 10 y 15 años esa gran porción de la población en edad infantil y juvenil serán los que tendrán en sus manos las posibilidades de cambio y desarrollo del país. Su vinculación con los medios y los contenidos que de ellos perciben ¿les estarán permitiendo formar una identidad y formas culturales que les permitan contribuir

\footnotetext{
${ }^{6}$ Los segmentos de mayor crecimiento han sido los $\mathrm{D}+$ y D/E. La distribución poblacional es la siguiente: $\mathrm{ABC}+40 \%$, C $20 \%$, D $+27 \%$ y D/E 14\%. Lo cual habla de una mayor democratización del uso y consumo de Internet.
} 
prosocialmente en el complejo entramado social, económico e institucional que está conformando?

Si se revisa a detenimiento la composición social, casi el $50 \%$ de la población se ubica en la categoría de mercado potencial de un sin fin de bienes, productos y servicios. A esta población que antes no se le veía ni escuchaba, hoy se les contempla como los destinatarios principales de la comunicación por su poder de compra y de presión en la toma de decisión. Sus opiniones definen las estrategias del mercado; su patrón de consumo describe quiénes son, a qué círculos y comunidades pertenecen y qué acciones definen lo que da sentido a sus vidas. Ya lo anunciaba Juliet Schor (Schor, 2006) cuando advertía de la aparición de una generación nacida para comprar.

\section{Tabla 1: Población de niños, adolescentes y jóvenes de la República Mexicana}

\begin{tabular}{|l|l|r|r|r|r|r|r|r|}
\hline & Total & De 0 a 4 anios & De 5 a 9 anios & De 10 a 14 anios & De 15 a 19 anios & De 20 a 24 años & De 25 a 29 años & De 30 a 34 años \\
\hline Total & $66,761,063$ & $10,186,243$ & $10,511,738$ & $10,952,123$ & $10,109,021$ & $8,964,629$ & $8,103,358$ & $7,933,951$ \\
\hline Hombre & $32,861,994$ & $5,175,913$ & $5,339,127$ & $5,545,910$ & $4,995,906$ & $4,253,440$ & $3,805,724$ & $3,745,974$ \\
\hline Mujer & $33,899,069$ & $5,010,330$ & $5,172,611$ & $5,406,213$ & $5,113,115$ & $4,711,189$ & $4,297,634$ & $4,187,977$ \\
\hline
\end{tabular}

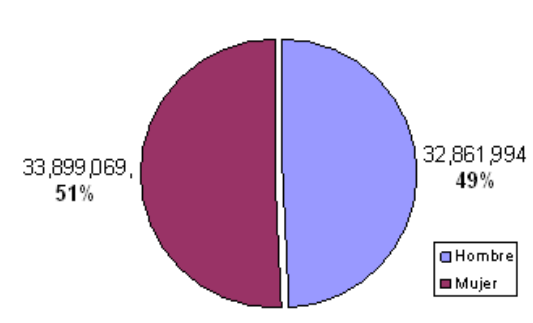

Fuente: II Conteo de Población y Vivienda 2005

Los medios, como prolongación esencial de la vida, deben ser juzgados no con un afán condenatorio sino con miras a desentrañar sus limitaciones y posibilidades. Si los jóvenes hoy día emplean los medios para entender cómo es su sociedad, extraer opiniones sobre los diversos aspectos de la vida y construir con ello su propio yo (Montero Rivero, 2006) habrá que plantearse los cuestionamientos éticos que deriven de las interacciones mediáticas y sociales y ver cómo aprovecharlos más que para seguir construyendo consumidores, para formar personas íntegras que puedan contribuir al desarrollo del país. 


\section{Las nuevas identidades juveniles hipermediatizadas}

"La vida se hace más amplia, sobre todo son escenarios alternativos a la aburrida vida de cualquier joven urbano. La vida no tan urbana está más repleta es igualmente aburrida. Están muy aburridos, o son unos zombies. Un mundo cerrado con apariencia de abierto, la vida social es corta y se aferran a lo poco para respirar. La familia no es opción, es otro sistema muy cerrado y aburrido". (Entrevista a Expertos, EaE17', México, DF, México)

México se está convirtiendo en una nación con características urbanas. Particularmente en este momento se cuenta con un bono poblacional marcadamente juvenil pero que poco a poco tiende a envejecer, lo que nos llevará a tener próximamente un país de adultos. En ese contexto se está dando un incremento de los niveles educativos y un mayor acceso a herramientas tecnológicas para adscribirse a la Sociedad de la Información. Educación, ocio y urbanización tienen una gran relación con acceso a las tecnologías de información y comunicación. En este gran cambio estructural también se incrementaron los espacios habitacionales, descendió el número de ocupantes por viviendas, pero aumentó el equipamiento electrodoméstico; particularmente aumentó la posesión de bienes comunicaciones en el hogar mexicano. Este cambio, reconfiguró los hábitos de consumo mediático e hipermediático. Los tipos de receptores y las formas de recepción son totalmente diferentes a lo que conocíamos hace algunos años. Las prácticas y procesos comunicativos han cambiado. Se pasó del consumo pasivo a un consumo activo. Hoy las audiencias están estableciendo compromisos más profundos con los medios. De acuerdo a los distintos estudios de consumo de medios, se ha democratizado parcialmente el acceso a los mismos, ya cada vez más sectores de la población tienen la posibilidad de participar de la lógica mediática e incorporar en sus vidas en modo profundo las tecnologías de información y comunicación.

\footnotetext{
${ }^{7}$ A partir de este momento la referencia EaE corresponde a la serie de comentarios expresados por los expertos entrevistados.
} 
Existen, por tanto, nuevas formas de acceso, nuevos escenarios de uso, una comunicación más individualizada e interpersonal. Los hipermedios se han vuelto el equipamiento básico de las nuevas generaciones desplazando en algunos casos a los medios tradicionales. Existe, por tanto, un incremento sostenido del uso de las TIC por públicos juveniles quienes están modificando sus prioridades, expectativas, posibilidades, volúmenes de uso, niveles de intensidad de la conexión, tipos de contenidos consumidos y relaciones establecidas con ellos.

Los medios juegan hoy un rol fundamental en la vida de las personas; con ello están desarrollando nuevas construcciones simbólicas y configuraciones de su identidad. La construcción de la identidad es en sí misma una construcción de la realidad. Hoy se habla de identidades múltiples, mutables y vinculadas con las prácticas sociales, políticas y mediáticas. La identidad se construye desde los significados y hábitos que se cristalizan en la acción humana.

Las juventudes digitales están usando los medios para producir y reproducir sus representaciones, para dotar de sentido su existencia. En los medios están articulando sus identidades; por tanto, los medios se han vuelto puentes simbólicos, narrativos en cuyo entramado se están configurando constelaciones hipermediáticas.

Un nuevo entablado histórico existencial se está tendiendo entre el individuo y estos contextos en movimiento. La identidad como una red de comunicación, de representaciones dialógicas, puede leerse como un texto abierto. La comprensión de sus códigos implica entender las nuevas realidades y comprender las nuevas configuraciones sociales, las relaciones, lo estructurante, lo objetivado, las luchas hegemónicas y las formas de sematizar la realidad. La sociedad mediática son relaciones estructuradas en la que las representaciones están negociando sus significados.

Las identidades juveniles y la cultura popular son dos estadios simbólicos que convergen hoy en el espacio mediático y es desde ahí, donde se está resignficando el mundo. Desde los medios las personas se están definiendo, construyendo, entendiendo y adjudicando 
pertenencia. El consumo se ha vuelto para los jóvenes una forma de construcción de personalidades e individualidades. La dialéctica actual es desde la triada medios-cultura-identidad. Las prácticas cotidianas participan de esta lógica de interacción-gratificación y construcción de sentido y es que los medios se han vuelto el laboratorio para la construcción de una nueva identidad hipermedial. Los medios reconfiguraron la cultura, ahí es posible ubicar los nuevos significados sociales. Los medios se han vuelto el punto de referencia, la subestructura que soporta la vida social, las prácticas comunicativas, los diálogos culturales.

La relación medios-jóvenes-cultura, es una relación que se ha construido desde casi el origen mismo de los medios; sin embargo, hoy dejaron de ser un simple pasatiempo para ser uno de los referentes que da significado a sus vidas. Un significado que permea en la esfera económica, social y cultural. Los medios de comunicación, los hipermedios y las tecnologías virtuales no son un contexto por sí mismo, sino que son una parte de la textura, de la dinámica de los actores, los objetos, las conexiones, las prácticas sociales y los significados actuales.

Los territorios del ciberespacio son la producción, el uso de las nuevas tecnologías, las comunidades mediadas por computadoras, los estudios de la cultura popular en la ciencia y la tecnología, el crecimiento y el desarrollo cualitativo de la comunicación humana mediada por computadoras y la economía política de la cibercultura.

\section{Conclusión. Repensar lo juvenil desde lo mediático}

"Los jóvenes hemos adoptado un estilo de vida a partir de la tecnología. Los medios tradicionales convergen con el internet y es así como el disfrute y la consulta de información se volvieron atemporales. Por eso influyen en abastecer de información, formar cultura y opinión, además de entretener". (Sujeto Informante Digital, SID87, México DF, México)

Los medios cambiaron al mundo y con ello, cambiaron también a las audiencias. Los estudios de consumo mediático dejan ver cómo desde sus inicios los estudios de comunicación notaron el impacto que 
estaban teniendo los medios en la manera como se comprendían y vivían los derechos de los niños y jóvenes. En su condición de inmadurez biológica e intelectual se les contempló como audiencias vulnerables y altamente expuestas a contenidos cargados de violencia, lenguaje explícito y promotores de actividades propias de la vida adulta. De esta visión proteccionista se pasó al estudio de la relación de los medios como articuladores de la realidad social.

Crecer y vivir en un mundo saturado de medios que aportan visiones del mundo y formas de ser, estar y comportarse en él es la naturaleza de las personas desde mitad del siglo pasado. Los medios, como experiencias vitales y puertas de acceso al mundo para los jóvenes, se han convertido en interfaces que les permiten participar en los procesos sociales, económicos, culturales e ideológicos.

Este texto registró la telemediatización y conectividad global que están viviendo las audiencias y la urgencia que existe por formar en los usuarios pensamiento crítico, activo y propositivo de tal forma que puedan participar, comunicarse, interactuar, socializar en un contexto reticular y global. Los jóvenes, están viviendo en un momento particular de la historia en que el individualismo, consumismo y crisis de las instituciones los ha llevado a establecer vínculos más profundos con los medios. Los medios se han vuelto el punto de convergencia entre las culturas juveniles, la cultura popular, las prácticas identitarias, los escenarios donde se amplifica la vida urbana y su corporalidad.

Este texto pretendió dar cuenta de la condición juvenil más allá de la dimensión biológica y psicológica para situarla en el contexto sociocultural, dado que la noción de juventud en sí misma es una construcción social relacional. Por tanto, sirvió de cartografía a los lectores para navegar por las distintas culturas, prácticas y formas de autorreconocimiento y heterorreconocimiento de las culturas juveniles y sus consumos mediáticos particulares.

Por tanto, se ha situado una dimensión más para comprender al joven en el campo social: la mediatizada. La condición mediatizada se refiere a los jóvenes que están permanentemente estructurando y reconfigurando sus prácticas sociales y culturales desde la dimensión 
mediática. Los medios han dotado a los jóvenes de distintos capitales que les permiten acceder, poseer, usar y acumular capitales políticos, culturales, sociales y simbólicos. En ese mediado, lo joven se torna una metáfora del cambio social, de la movilización, de la negociación de las nuevas prácticas culturales, estéticas y simbólicas. De la apropiación intangible de espacios y territorios en los que trazan nuevos itinerarios y rutas de significación.

Si los medios son el espacio social juvenil, donde se estructura y articula la configuración de la identidad de las audiencias, es importante comprender la manera como se está constituyendo el campo, la manera como se establecen las prácticas, distinciones, gustos, significaciones y actitudes. Los medios como marcadores y redes de definición de los individuos concentran la dimensión comunicativa, creativa, espacial y expresiva de las personas. Existe pues, una nueva ecología donde medios y tecnología están cambiando la vida de las personas y reconfigurando al mismo mundo.

Los medios y las TICs como herramientas para moldear y modificar la realidad nos presentan un nuevo horizonte con retos, riesgos y oportunidades. Temas como inclusión, exclusión, hibridez, aprendizaje, competencias digitales, participación cívica, desarrollo, autorregulación, libertad de expresión, conexión y juego se incorporan en la agenda de estudio y análisis de esta nueva condición del ser en la era digital. Las tecnologías de información y comunicación y su acelerado proceso evolutivo y de incorporación en la vida y los contextos dislocaron por completo nuestras experiencias temporales, espaciales, cognitivas y existenciales. Su capacidad para envolver y amplificar la vida, sedujeron a los usuarios. Los llevaron a pasar de una condición pasiva a otra más activa. Hoy las nuevas generaciones mediáticas procesan información y comprometen sus talentos con los nuevos medios y dispositivos. Desde ellos exploran normas, hábitos, costumbres y nuevas amistades.

Dada esta nueva realidad se ha constituido una cultura hipermediática, con nuevas tipologías de audiencias, agencias y hábitos. El espacio mediático es el espacio del ser, es el lugar donde el yo se presenta en modo híbrido, de forma atemporal, instantánea, hiperconectado, 
deslocalizado, inmaterial y soportado por la gravidez simbólica que permite su codificación. La mediósfera (Debray), la mediópolis (Silverstone), la tecnópolis (Postman), la ciberpolis (Bauman) no son otra cosa que ese espacio híbrido que se tiende entre la realidad física, la virtual y la mental. Son el soporte que conecta todos los espacios y que permiten al individuo incrustarse de modo natural en ese horizonte de estructuras y ambientes simbólicos donde es posible vivir, trabajar, moverse, ejercitarse y divirtiese en cuerpo y mente en varios espacios a la vez.

Hoy estamos ante ciberculturas juveniles que extienden sus prácticas y representaciones en los entornos hipermediales. Vida y pantallas engranaras; socialidades, tecnicidades y subjetividad en red se cuestionan y construyen sentidos cada vez que se conectan, instalan, encuentran y estructuran en estos contenedores simbólicos. Hoy los jóvenes están moldeando sus identidades individuales y colectivas en relación con los otros desde los medios; ahí establecen significados sociales, formas de identificación-diferenciación social y consolidación de la cultura-mundo.

Esta nueva forma de sociabilidad, percepción y sensibilidad desde las pantallas implica nuevos abordajes territoriales de las culturas juveniles

\section{Referencias}

Asociación de Internet Mx. (2018). $14^{\circ}$ Estudio sobre los Hábitos de los Usuarios de Internet en México 2018. Recuperado el 20 de Febrero de 2019, de Asociacion de Internet.mx:

file://C:/Users/jhidalgo/Downloads/14+Estudio+sobre+los + Ha_bitos+de+los+Usuarios + de+Internet + en $+\mathrm{Me}$ _xico +201 $8+$ versio_n+pu_blica $\% 20(1) \cdot p d f$

Bauman, Z. (2009). Vida de consumo. México DF, México: Fondo de Cultura Económica.

Bauman, Z. (2010). Mundo consumo: Ética del individuo en la aldea gobal. México DF, México: Editorial Paidós mexicana S.A. de C.V. Bruni, A. (2005). Shadowing software and clinical records: On the ethnography of non-humans and heterogeneous contexts. Organization, 12(3), 357-378. 
Buckingham, D. (2005). Educación en medios: Alfabetización, aprendizaje y cultura contemporánea. Barcelona: Ediciones Paidós Ibérica, S.A. . Buckingham, D. (2008). Youth, Identity, and Digital Media. Cambridge, Massachusetts: MIT Press.

Clynes, M. E., \& Kline, N. S. (1960). Cyborgs and space. Astronautics, 26, 75-76.

Daniels, J. (2008). Race, civil rights, and hate speech in the digital era. En A. Everett, Learning Race and Ethnicity: Youth and Digital Media (págs. 129-155). Cambridge, Massachusetts, EUA: The MIT Press.

David, P. (1999). Children's Access to Media and Media Use. En C. Von Feilitzen, \& U. Carlsson, Children and Media. Image Education Participation. Yearbook 1999. Gothenburg, Suecia: Nordicom.

Del Fresno García, M. (2011). Netnografía: investigación, análisis e intervención social online. Barcelona, España: Editorial UOC.

Eco, U. (1996). De la Internet a Gutenberg. In A. I. Avanzati (Ed.), Conferencia pronunciada el 12 de noviembre de 1996 en la Academia Italiana degli Studi Avanzati. Academia Italiana degli Studi Avanzati.

Etchevers Goijberg, N. (junio de 2005). Ruta etnográfica para la comprensión de la comunicción on-line. Revista electrónica DIM, Año 1(1).

Gherardi, S. (2005). Organizational knowledge: The texture of workplace learning. Oxford: Blackwell.

Giddens, A. (2005). Un mundo desbocado: los efectos de la globalización en nuestras vidas. Barcelona, España: Taurus.

Goetz, J. P., \& LeCompte, M. D. (1988). Etnografia y diseño cualitativo en investigación educativa. Madrid, España: Morata.

Gómez Vargas, H. (2008). Estratos espaciales y de comunicación en los estudios sobre la juventud. Una revisión de los estudios de los consumos culturales juveniles en México. En M. A. Rebeil Corella, XV Anuario de Investigación de la Comunicación, CONEICC (págs. 185-214). México: CONEICC, U. Anáhuac, U. Mayab, U. Iberoamericana León, U. Autónoma de San Luis Potosí, Tecnológico de Monterrey.

Hakken, D. (1999).Cyborg@Cyberspace.An ethnographer looks to the future. Nueva York: Routledge. 
Haraway, D. (1991). Simians, cyborgs and women: The reinvention of nature. Nueva York: Routledge.

Hidalgo Toledo, J. (2007). I-dentidad hipermedial: nuevos medios, nuevas audiencias, ¿nuevas identidades? In M. Mercado, A. Gómez, \& S. I. Congreso (Ed.), La Comunicación en la Comunidad Visual (pp. 19-23). Distrito Federal, México: Universidad La Salle.

Hine, C. (2004). Etnografía virtual. Barcelona, España: Editorial UOC. Instituto Nacional de Estadística y Geografía. (2005). El INEGI da a conocer los Resultados Definitivos del II Conteo de Población y Vivienda 2005. (I. N. Geografía, Ed.) Retrieved 2010 йил 3-marzo from http://www.inegi.org.mx/sistemas/comunicados/AbrirArchiv o.aspx?a $=2006 \& \mathrm{~m}=5 \& \mathrm{n}=$ comunica $4 . \mathrm{pdf}$

Latour, B. (1999). Pandora's hope: Essays on the reality of science studies. Cambridge, Massachussetts: Harvard University Press.

Levy, P. (1999). ¿Qué es lo virtual? Buenos Aires, Argentina: Paidós. Levy, P. (2007). Cibercultura. La cultura de la sociedad digital. Barcelona, España: Antrophos Editorial y Universidad Autónoma Metropolitana.

Livingstone, S. (1990). Making sense of television: the psychology of audience interpretation. Oxford, Reino Unido: Pergamon Press.

Livingstone, S. (2009). Children and the internet. Cambridge, Inglaterra: Polity Press.

Livingstone, S., Holden, K., \& Bovill, M. (1999). Children's Changing Media Environment. Overview of a European Comparative Study. En C. Von Feilitzen, \& U. Carlsson, Children and Media. Image Education Participation. Yearbook 1999. Gothenburg, Suecia: Nordicom.

Lofland, J. (1971). Analyzing social settings: a guide to qualitative observation and analysis. Belmont, California: Wadsworth.

Martel, F. (2011). Cultura Mainstream: Cómo nacen los fenómenos de masas. DF, México: Taurus.

Mauss, M. (2006). Manual de Etnografía. Buenos Aires, Argentina: FCE.

McLuhan, M. (1998). La galaxia Gutenberg. Barcelona, España: Círculo de Lectores.

Montero Rivero, Y. (2006). Televisión, valores y adolescencia. Barcelona, España: Gedisa. 
Morduchowicz, R. (2008). Los jóvenes y las pantallas: Nuevas formas de sociabilidad. Barcelona, España: Gedisa.

Peña, A. (2006). Hábitos de los Usuarios de Internet en México, 2006. Asociación Mexicana de Internet, Dirección Comercial Televisa Digital. Distrito Federal, México: Asociación Mexicana de Internet.

Peña, A. (2007). Hábitos de los Usuarios de Internet en México. Asociación Mexicana de Internet, Dirección Comercial Televisa Digital. Distrito Federal: Asociación Mexicana de Internet.

Poniewozik, J. (2005). The big fat year in culture. En R. B. Browne,

Profiles of popular culture: a reader (págs. 376-388). Madison,

Wisconsin, EUA: The University of Wisconsin Press.

Reguillo, R. (2007). Legitimidad(es) divergentes. En IMJ, Jóvenes

Mexicanos. Encuesta Nacional de Juventud 2005 (Vol. I, págs. $77-$

133). México: IMJ/SEP.

Reguillo, R. (2010). Los jóvenes en México. México DF, México: Fondo de cultura económica.

Reguillo, R. (2010). Los jóvenes en México. México: Fondo de Cultura

Económica, Consejo Nacional para la Cultura y las Artes.

Rheinglod, H. (1996). La comunidad virtual: Una sociedad sin fronteras.

Barcelona, España: Editorial Gedisa, S.A.

Schor, J. (2006). Nacidos para comprar: los nuevos consumidores infantiles.

Barcelona, España: Paidós.

Silverstone, R. (1994). Televisión y vida cotidiana. Buenos Aires, Argentina: Amorrortu Editores.

Silverstone, R. (2004). ¿Por qué estudiar los medios? Buenos Aires, Argentina: Amorrortu.

Tapscott, D. (2000). La creación de valor en la economía digital. Buenos Aires, Argentina: Ediciones Granica S.A.

Teli, M., Pisanu, F., \& Hakken, D. (Septiembre de 2007). The internet as a Library-of-People: for a cyberethnography of Online Groups,.

Recuperado el 20 de octubre de 2012, de Forum: Qualitative Social Research. Vol. 8, No. 3 (2007): http:/ /www.qualitativeresearch.net/index.php/fqs/article/view/283/621/

Umaschi Bers, M. (2008). Civic identities, online technologies: from designing civics curriculum to supporting civic experiences. En W. L. Bennett, Civic Life Online: Learning How Digital Media Can 
Engage Youth (págs. 139-160). Cambridge, Massachusetts, EUA: The MIT Press.

Urteaga Castro-Pozo, M. (2010). Género, clase y etnia. Los modos de ser joven. En R. Reguillo, Los jóvenes en México (págs. 15-51).

México: Fondo de Cultura Económica, CONACULTA.

Urteaga, M. (2011). La construcción juvenil de la realidad: jóvenes mexicanos contemporáneos. México: Universidad Autónoma Metropolitana/Juan Pablos Editor.

Watkins, S. C. (2009). The young \& the digital: What the migration to socialnetwork sites, games, and anytime, anywhere media means for our futur. Boston, Massachusetts: Beacon Press. 

Percepciones sobre el comportamiento comunicacional y las vulnerabilidades digitales de los menores. Cruce interdisciplinar ${ }^{8}$

\author{
Antonio García-Jiménez \\ Universidad Rey Juan Carlos (España) \\ antonio.garcia@urjc.es \\ Beatriz Catalina-García \\ Universidad Rey Juan Carlos (España) \\ beatriz.catalina@urjc.es \\ Manuel Montes-Vozmediano \\ Universidad Rey Juan Carlos (España) \\ manueljavier.montes@,urjc.es
}

\begin{abstract}
PARA CITAR: García-Jiménez, A.; Catalina-García, B. \& MontesVozmediano, M. (2019). "Percepciones sobre el comportamiento comunicacional y las vulnerabilidades digitales de los menores. Cruce interdisciplinar”. En Barredo Ibáñez, D.; Cunha, M. R. \& Hidalgo Toledo, J. (Eds.) (2019). Jóvenes, participación y medios de comunicación digitales en América Latina <pp. 47-60>. La Laguna, España: Cuadernos Artesanos de Comunicación. DOI: 10.4185/cac156
\end{abstract}

\title{
Resumen
}

Con una mirada comunicológica, esta investigación indaga en las percepciones y planteamientos de los futuros docentes en educación infantil y de los futuros profesionales de la comunicación en relación con el uso, impacto y dimensión educativa de la vida digital de los menores. A tal efecto, se revisan las bases de tres ámbitos de

\footnotetext{
${ }^{8} \mathrm{El}$ presente trabajo forma parte del Programa de Actividades sobre Vulnerabilidad Digital PROVULDIG-CM (S2015/HUM-3434) financiado por la Comunidad de Madrid y el Fondo Social Europeo, en Ciencias Sociales y Humanidades (2016-2019).
} 
estudio/trabajo: los usos y riesgos digitales, la vulnerabilidad digital y la educación mediática y digital. Esta investigación se realiza por medio de un cuestionario a estudiantes de Grado en Educación Infantil y un grupo de discusión a alumnos del Máster en Comunicación y Problemas Socioculturales, ambos de la Universidad Rey Juan Carlos (Madrid, España), sobre tres ejes: a) usos y percepciones de las nuevas tecnologías; b) vulnerabilidad y riesgos y c) medidas preventivas para un empleo adecuado. Algunas de sus conclusiones están relacionadas con la importancia de las TIC en las estrategias parentales y docentes, en el dominio escolar y en las proyecciones educativas.

\section{Palabras clave}

TIC, Menores, Educación, Alfabetización mediática.

\section{Introducción}

$\mathrm{E}$ STA INVESTIGACIÓN, de naturaleza cualitativa, tiene como bases de trabajo la investigación dirigida a los riesgos en línea, a las vulnerabilidades digitales, y la alfabetización mediática y digital (García-Jiménez et al., 2017). El objetivo es determinar la percepción de futuros educadores, así como profesionales de la Comunicación, en un cruce epistemológico proyectivo, al respecto de la vida digital de los menores y sus vinculaciones comunicativas y educativas. Con este planteamiento, se ha realizado un conjunto de entrevistas escritas y se ha efectuado un grupo de discusión.

\section{Riesgos digitales}

En términos generales, el acceso a Internet es un hábito plenamente consolidado entre menores y jóvenes. El uso intensivo de los denominados dispositivos de pequeño formato, como los smartphones, y la conexión constante a las redes sociales está originando la aparición de nuevos fenómenos como el miedo a perderse algo (fear of missing out o FoMO) que son elementos predictores de síntomas psicopatológicos como la ansiedad (Gil et al., 2015). 
Si bien los menores manejan con soltura la tecnología, este hecho no significa que entiendan y asimilen sus peligros (De-Frutos y Marcos, 2017; Guerrero, 2017), ya que realizan acciones que les colocan en situación de riesgo: publicar vídeos en espacios privados y sin proteger su identidad (Montes-Vozmediano et al., 2018), visualizar contenido inapropiado o acceder a sitios web con software malicioso (Haz et al., 2017), o tener contacto con desconocidos (Fernández et al., 2015). Los estudios indican, además, que estas conductas inadecuadas de los menores, asociadas al uso indebido de las redes sociales en particular y de Internet en general, en vez de disminuir, van en aumento (Garmendia et al., 2016).

El entorno social y familiar se configura como un factor clave en la prevención y disminución de los riesgos en Internet ya que los menores, más proclives que los adultos a exponer su privacidad en la Red y más reacios a aplicar medidas de seguridad (Walrave et al., 2015) prefieren relatar a sus amigos, antes que a sus progenitores, las situaciones conflictivas que acaecen en la Red (Jiménez Iglesias et al., 2015).

Parece necesario lograr la implicación global de la sociedad, tanto de instituciones públicas como privadas (Guerrero, 2017); y contar también con las diversas experiencias exitosas que se han logrado a este respecto en países como Brasil (Gregorio, 2011). En todo caso, estas acciones genéricas son complementarias a la labor pedagógica directa que se debe realizar con los menores (Alfaro González et al., 2015) y con sus padres o tutores para que actividades de riesgo, como el acceso a contenidos inapropiados o las invitaciones o solicitudes molestas, no deriven en situaciones más problemáticas como el ciberacoso (GarcíaJiménez et al., 2015).

Los jóvenes emplean el social media como canal informativo, de asuntos locales y globales (Vizcaíno-Laorga et al., 2019) y vehículo formativo, si bien el material consultado se presenta mayoritariamente en estructuras modales y orientaciones que indican una falta de problematización de temas que potencialmente sí lo son (García Jiménez \& Montes Vozmediano, 2019). 


\section{Vulnerabilidad digital}

Uno de los modos de abordar la vulnerabilidad digital tiene que ver con los factores que condicionan la denominada brecha digital, que autores como Korupp y Szydlik (2005) reducen a tres dominios: el contexto familiar, social, y el capital humano, en alusión al nivel formativo y profesional.

Con mayor frecuencia se aborda el estudio, y se realizan acciones para la reducción de brechas como la cultural, la económica (Gil-Juárez et al., 2011), o la de género (Jiménez Cortés et al., 2016), mientras que las padecidas por personas con alguna discapacidad ya sea física (Escandell et al., 2014; Mayor Pérez y Bacallao-Pino, 2015) o intelectual, son menos atendidas. En cualquier caso, son destacables los resultados positivos obtenidos, en este caso desde una perspectiva colombiana (Flórez et al., 2016), a partir de las diferentes experiencias del manejo de las TIC entre el colectivo de personas con discapacidad intelectual, y que demuestran la necesidad de llevar a cabo políticas públicas de acción social. No debemos olvidar que la brecha digital no es exclusiva de los países pobres, ya que también afecta, aunque con otros condicionantes, a las naciones ricas (Serrano y Martínez, 2003).

Por otra parte, una brecha como la generacional es más sencilla de reducir, siendo especialmente relevante ya que condiciona los usos y conocimientos tecnológicos, incidiendo en la tarea pedagógica de los progenitores. Así, los jóvenes minusvaloran las competencias tecnológicas de los adultos (Garrido-Lora et al., 2016) y esta sensación de inferioridad de los mayores condiciona su labor pedagógica.

\section{Alfabetización mediática y tecnológica}

Otro de los aspectos que se deben tomar en consideración tiene que ver con la alfabetización mediática y también la tecnológica. A título ilustrativo, en el caso español, tal y como apuntan autores como Ferrés et al. (2011, p. 39), es patente el insuficiente nivel de competencia mediática de los ciudadanos. Aunque las carencias son menores entre los jóvenes, todavía se necesita una atención profunda, posiblemente con la excepción del plano puramente tecnológico, donde este sector 
de la población presenta una clara adaptación frente a generaciones anteriores.

Así, tal y como señalan García-Ruiz et al. (2014), existe un nivel aceptable de uso de dispositivos tecnológicos pero una baja capacidad crítica (mediática), tanto analítica como productiva, en lo que se refiere a lo mediático. Dicho de otra forma: a la competencia digital, que cada vez más se incluye en los itinerarios escolares, hay que sumar necesariamente la competencia mediática.

De hecho, y ya en una consideración casi planetaria, autores como Prensky (2001) señalan que a los nativos digitales se les presupone unas habilidades que no son corroboradas por la investigación "ad hoc". Y, además, algunas competencias técnicas enmascaran la ausencia de otras básicas, especialmente en lo que se refiere al acceso y uso de la información (Cabra y Marciales, 2009). En este contexto, se puede acudir a las palabras de De Pablos (2012) al señalar que "el gran desafío al que tienen que dar respuesta las políticas educativas de incorporación de las TIC a las escuelas, no es únicamente el de dotar de herramientas informáticas a los centros educativos, para que sean utilizadas por los estudiantes y el profesorado, sino que deben vincularse a un proyecto de reforma e innovación educativa general, lo que implica una remodelación de las propuestas, de manera que permitan reconsiderar el sistema educativo como un todo" (De Pablos, 2012, p. 112).

En definitiva, la educación mediática se constituye como un factor clave en el desarrollo de las personas, dando lugar a una ciudadanía más implicada y participativa, especialmente en los sectores de la población más jóvenes, y en todas las latitudes (Romero-Rodríguez et al., 2016).

\section{Metodología de investigación}

Para el desarrollo de este trabajo se han adoptado dos técnicas diferenciadas: por una parte, se aplicó una encuesta con preguntas cerradas y respuestas abiertas y, por otra, se llevó a cabo un grupo de discusión. En la primera de ellas se pidió las opiniones, anónimas y por escrito, de 23 estudiantes de Grado matriculados en la asignatura de Comunicación y Educación Infantil de la Universidad Rey Juan Carlos 
(Madrid-España). El grupo de discusión se estableció entre 9 alumnos del Máster de Comunicación y Problemas Socioculturales de la misma universidad; la sesión tuvo una duración de 56 minutos.

Tanto las edades de los entrevistados como de los participantes en los grupos de discusión oscilan entre los 18 y los 27 años; es decir, nacidos en la última década del siglo pasado y que constituyen la denominada generación de los Millenials, término que engloba a los primeros jóvenes que han nacido y crecido en la era digital. Su visión, en el contexto que nos movemos, resulta altamente relevante ya que parten de su propia experiencia en el uso frecuente de las nuevas tecnologías. Se destaca, además, la formación universitaria que están recibiendo estos jóvenes, relacionada en ambos casos con la incidencia de Internet y las nuevas tecnologías en grupos sociales vulnerables; con un enfoque general entre los estudiantes del Máster y desde un punto de vista particularizado en la infancia entre los alumnos de Grado.

Previamente, se establecieron una serie de ejes temáticos comunes que sirvieron, respectivamente, como base de las preguntas del cuestionario y como líneas orientativas expuestas por el investigador-moderador durante la discusión del grupo: a) usos y percepciones de las nuevas tecnologías; b) vulnerabilidad y riesgos y c) medidas preventivas para un empleo adecuado.

\section{Resultados}

\subsection{Visión sobre el uso de las nuevas tecnologías}

Todos los jóvenes, tanto los encuestados como los participantes en el grupo de discusión, coinciden en señalar las amplias y numerosas oportunidades que brindan las nuevas tecnologías para el desarrollo del menor. Dispositivos como la pizarra digital, tablets, móviles, e incluso la televisión se califican como herramientas ya imprescindibles en la enseñanza. Los estudiantes de Educación Infantil destacan su importancia para la participación en clase, la interacción con los compañeros y para la adquisición de nuevas competencias vinculadas al aprendizaje. 
La exposición en el aula de videos, la muestra de páginas web adecuadas, el acceso a portales digitales especializados, la participación en juegos online didácticos (gamificación) y la capacitación para que se desarrollen como booktubers (jóvenes que utilizan un canal de YouTube para compartir comentarios sobre libros que han leído) son algunos de los aspectos positivos que, según entienden los universitarios, pueden ser aprovechados en la enseñanza al menor.

Igualmente, las redes sociales son, en opinión de los participantes en la discusión, potencialmente útiles como herramienta didáctica y de comunicación entre profesores y estudiantes, principalmente las más populares: Twitter y sobre todo Facebook que puede ser más atractiva para los niños. No obstante, en este punto se observan divergencias: algunos de los sujetos de la investigación ponen en tela de juicio que las redes puedan ser efectivas como herramienta de aprendizaje; este escepticismo se debe a la cantidad de información que se publica y cuya autoría no está siempre garantizada.

Otro de los beneficios que aportan las tecnologías se deriva de la socialización; como aspecto puntual, uno de los participantes en el grupo de discusión considera una importante ventaja que los menores, "que están deseando conocer todo", puedan disponer de estos dispositivos en áreas geográficas rurales con recursos y población muy limitados. En relación con otros casos particulares, algunos de los encuestados también consideran pertinente la utilización de material tecnológico para niños con diferentes tipos de discapacidad, especialmente las relacionadas con los sentidos y con la psicomotricidad.

La mayoría de los jóvenes que estudian Educación Infantil y la práctica totalidad de los participantes en el grupo (solo una joven muestra su disconformidad) apuestan por el uso de lo digital para el desarrollo del menor; aunque sí matizan que se debe limitar su uso, o incluso evitarlo, a determinadas edades. Al respecto, en la discusión coinciden en señalar que a partir de los 14-15 años adquieren ya autonomía y capacidad para seleccionar contenidos adecuados, y algunos de los entrevistados sugieren que se retrase lo máximo posible el acceso al entorno digital. No obstante, los universitarios, por su experiencia, son 
conscientes de que los menores navegan por Internet y disponen de su propio perfil en redes sociales desde edades más tempranas porque, aunque no se lo permitan en el hogar, reciben la influencia de su entorno de amigos y tienen numerosas facilidades para acceder a dispositivos fuera del hogar.

\subsection{Vulnerabilidad, riesgos y daños}

La falta aún de un sentido crítico entre los menores es uno de los factores que los universitarios exponen para argumentar la vulnerabilidad y el riesgo que potencialmente conlleva la navegación por Internet y el uso de las tecnologías en edades tempranas. Sin embargo, es significativo que esta cuestión es banalizada entre aquellos participantes de la discusión que reconocen un alto consumo de lo digital durante su etapa infantil y adolescente, mientras que aquellos que han mantenido un consumo moderado en su infancia $y / 0$ conviven actualmente con menores muestran una gran preocupación por los daños que puede generar un uso indiscriminado.

Entre los problemas físicos que puede conllevar el uso de internet se resaltan los relacionados con la vista y el oído, además del sedentarismo. En los cognoscitivos y emocionales, los entrevistados señalan los derivados en futuras adicciones a un medio y largo plazo y sugieren que en la enseñanza y educación del menor puede resultar peligroso anteponer el material tecnológico al tradicional (cuentos en papel o juguetes).

Es destacable que los jóvenes con un mayor contacto en su infancia con las nuevas tecnologías consideran que el anonimato que aporta las redes sociales no supone un riesgo, sino una oportunidad para que los menores que tienen problemas de socialización en el entorno offline puedan encontrar un modo de relacionarse en el ámbito digital. No obstante, esta opinión no es unánime y una gran parte de los participantes en la discusión consideran que el anonimato conlleva efectos nocivos para el menor que redundarán en una mayor dificultad para enfrentarse al mundo físico cuando tenga una edad más avanzada. Otra consecuencia que observan con respecto al anonimato es la posibilidad de que los menores difuminen su verdadera personalidad 
que aún no está forjada y generen finalmente un perfil identitario ficticio; aunque esta cuestión creen que solo se produce en situaciones extremas; en la generalidad de los casos los menores están creando una identidad online pero que no es muy distinta a la real porque, según los jóvenes, se produce un condicionamiento mutuo entre ambas identidades y no se detecta una desvinculación total entre el perfil del entorno físico y el que se crea en el mundo digital.

Entre los riesgos más graves, los universitarios muestran un diferente grado de preocupación en función del caso planteado. Con respecto al ciberacoso creen que su puesta en práctica es mucho mayor y más grave en la actualidad: "Los niños muestran una mayor maldad que nosotros cuando teníamos su edad/Mi hermanita me enseña algunos insultos que se difunden en las redes que yo ni tan siquiera conocía”. Sin embargo, el acceso a contenidos inadecuados (pornográficos o violentos) es considerado por la totalidad de los integrantes en el grupo de discusión como algo anecdótico y no creen que entrañará consecuencias graves para el desarrollo del menor; pero los entrevistados puntualizan que la exposición a contenidos inapropiados no solo de Internet, sino también televisivos, pueden influir en su progreso emocional y psicológico, imitando actitudes o asimilando términos impropios como insultos o expresiones soeces y procaces a los que incluso se puede acceder a través de determinados espacios que, a priori, están pensados para la edad infantil, como son los dibujos animados.

\subsection{Medidas preventivas y de control para un uso adecuado}

Todos los jóvenes sujetos de este estudio entienden que el control y la explicación continuada de los padres son fundamentales para que el menor utilice adecuadamente las nuevas tecnologías. Al respecto, los que contestan al cuestionario recomiendan una constante supervisión de los contenidos audiovisuales y la limitación del tiempo en el acceso a la televisión y a las plataformas digitales; igualmente sugieren que los menores estén acompañados por los adultos cuando están manipulando los dispositivos tecnológicos. 
Si bien los participantes de la discusión coinciden en el establecimiento de estas medidas, reconocen no obstante que, en la práctica, resulta muy complicado ejecutarlas ya que no todos los padres tienen el suficiente tiempo y disponibilidad para mantener un correcto control. En este punto exponen dos factores que consideran ya generalizados: por una parte, las largas jornadas laborales que deben cumplir la mayoría de los progenitores y que les impide estar vigilando a sus hijos todo el tiempo que ellos quisieran; y por otra, un menor conocimiento por parte de los padres sobre redes sociales y sobre otras aplicaciones que el demostrado por los nativos digitales.

En esta situación, consideran que lo importante es generar un ambiente de confianza en el hogar, y que sea la base para la explicación, de modo preventivo, de las consecuencias que pueden tener determinadas acciones.

En el entorno escolar, los jóvenes coinciden que la labor docente debe mantener como un pilar importante las nuevas tecnologías; aunque en este contexto, los futuros educadores de la infancia se muestran más moderados y señalan que no se debe plantear como base exclusiva de la enseñanza, sino que debe combinarse con otros medios no digitales. En este punto hay diversidad de opiniones en el grupo de discusión: aunque la mayoría muestra su acuerdo, los jóvenes con mayor acceso en su infancia a las nuevas tecnologías consideran que los contenidos audiovisuales y disponibles en Internet siempre serán más provechosos y eficaces que los tradicionales.

Finalmente, los participantes en el grupo de discusión consideran muy relevante el papel que pueden desempeñar los hermanos mayores cuya experiencia en las nuevas tecnologías es más amplio que la de los padres.

\section{Conclusiones}

Con esta investigación, de naturaleza cualitativa y proyectiva, se hace evidente la percepción de jóvenes estudiantes implicados en el ámbito de la Comunicación y la Educación, en relación a las oportunidades que ofrecen las nuevas tecnologías en el desarrollo del menor, más 
numerosas que los riesgos que pueden conllevar y las consecuencias de ellos. Sobresalen sus posibilidades para fines educativos, sustituyendo o en combinación con los materiales tradicionales.

No obstante, reconocen que el menor necesita una preparación previa para un uso adecuado. Del mismo modo, confirman que el papel del entorno es fundamental, principalmente de padres, profesores pero también de hermanos mayores. La acción que, según los jóvenes, deben desarrollar estos sujetos debe basarse en la generación de un ambiente de confianza y empatía explicando las consecuencias de sus acciones en Internet y que reemplace a posibles medidas coercitivas.

Mientras que algunos riesgos, como el acceso a contenidos inapropiados, son banalizados por el grupo de estudio, la posibilidad de presentarse en redes sociales con un perfil anónimo es considerada por algunos jóvenes como un peligro, si bien otros afirman que es una forma de facilitar el desarrollo emocional, cognitivo y psicológico de menores con menos habilidades sociales en el entorno físico. No obstante, sí perciben la existencia de determinados riesgos como la publicación de algunos contenidos, textos o imágenes, de cuyas derivaciones no son conscientes los menores.

\section{Bibliografía}

Alfaro González, M.; Vázquez Fernández, M. E.; Fierro Urturi, A.; Herrero Bregón, B.; Muñoz Moreno, M. F. y Rodríguez Molinero, L. (2015). Uso y riesgos de las tecnologías de la información y comunicación en adolescentes de 13-18 años. Acta Pediátrica Española, vol. 73, n. 6, e126-e135.

Cabra, F. y Marciales, G.P. (2009). Nativos digitales: ¿ocultamiento de factores generadores de fracaso escolar? Revista iberoamericana de educación, n. 50, p. 113-130. En: http://rieoei.org/rie50a06.pdf

De-Frutos, B. y Marcos, M. (2017). Disociación entre las experiencias negativas y la percepción de riesgo de las redes sociales en adolescentes. El Profesional de la Información, 26(1), 88-96. https://doi.org/10.3145/epi.2017.ene.09 
De Pablos, J. M. (2012). Políticas educativas TIC en tiempos de crisis. Campus virtuales, vol. 1, n. 1, p. 105-113. En: http://www.uajournals.com/campusvirtuales/journal/1/9.pdf Escandell Bermúdez, M. O.; Fortea Sevilla, M. S. y Castro Sánchez, J. J. (2014). La brecha digital en las personas con discapacidad visual. International Journal of Developmental and educational psychology, n.1, vol. 1

Fernández, J.; Peñalva, M.A. \& Irazabal, I. (2015). Internet Use Habits and Risk Behaviours in Preadolescence. [Hábitos de uso y conductas de riesgo en Internet en la preadolescencia].

Comunicar, 44, 113-121. https://doi.org/10.3916/C44-2015-12 Ferrés, J.; Aguaded, J. I. y García-Matilla, A. (2011). La competencia mediática de la ciudadanía española. Dificultades y retos. Icono 14, vol. 10, n. 3, p. 23-42.

Flórez Buitrago, D.; Ramírez García, C. y Ramírez García, S. (2016). Las TIC como herramientas de inclusión social. Cuadernos de Desarrollo aplicado a las TIC, vol. 5, n. 1, p. 54-67. En: https://www.3ciencias.com/articulos/articulo/las-tic-comoherramientas-de-inclusion-social/

García-Jiménez, A., Catalina-García, B. y Montes Vozmediano, M. (2015). Una aproximación a la educación mediática para el contacto con desconocidos en Internet. Comunicación y Hombre, n. 11, p. 101-114.

García-Jiménez, A., Montes Vozmediano, M. y Catalina-García, B. (2017, mayo) Alfabetización mediática y vulnerabilidad digital: una aproximación educativa y comunicológica. En III Congreso Internacional de Educación Mediática y Competencia Digital (pp. 94-107). Media Education Summit 2017, Segovia.

García Jiménez, A. \& Montes Vozmediano, M. (2019). Subject matter of videos for teens on YouTube. International Journal of Adolescence and Youth, (preprint). doi: 10.1080/02673843.2019.1590850

García-Ruiz, R., Ramírez, A. \& Rodríguez, M.M. (2014). Media Literacy Education for a New Prosumer Citizenship. [Educación en alfabetización mediática para una nueva ciudadanía prosumidora]. Comunicar, 43, 15-23. https://doi.org/10.3916/C43-2014-01 
Garmendia, M.; Jiménez, E.; Casado, M. Á. y Mascheroni, G. (2016). Riesgos y oportunidades en internet y uso de dispositivos móviles entre menores españoles (2010-2015). En:

https://www.ehu.eus/documents/10136/6317486/Txostena I nforme.pdf

Garrido-Lora, M.; Busquet Duran, J. y Munté-Ramos, R. A. (2016). De las TIC a las TRIC. Estudio sobre el uso de las TIC y la brecha digital entre adultos y adolescentes en España. Anàlisi. Quaderns de Comunicació $i$ Cultura, 54, p. 44-57.

Gil, F., Del Valle, G., Oberst, U. y Chamarro, A. (2015). Nuevas tecnologías - ¿Nuevas patologías? El smartphone y el fear of missing out. Aloma, 33(2), 77-83.

http://www.revistaaloma.net/index.php/aloma/article/view/2 $77 / 188$

Gil-Juárez, A.; Vitores, A.; Feliu, J. y Vall-Llovera, M. (2011). Brecha digital de género: una revisión y una propuesta. TESI, vol. 12, n. 2 , p. $25-53$

Gregorio, C. G. (2011), Niños y adolescentes en las redes sociales: una visión desde América Latina y el Caribe. En Piñar Mañas (coord.), Redes sociales y privacidad del menor (pp. 263-286). Madrid, Editorial Reus

Guerrero, R. (2017). Redes sociales: riesgos y amenazas. Cuaderno Jurídico y Político, vol. 2, n. 7, p. 1-4. En:

http://portalderevistas.upoli.edu.ni/index.php/cuadernojuridico-y-politico/article/view/493/685.

Haz, L., Guarda, T., Zambrano, I. \& Sánchez, C. (2017, June).

Internet based parenting control application on teenagers. In Information Systems and Technologies (CISTI), 2017 12th Iberian Conference on (pp. 1-6). IEEE.

Jiménez Cortés, R.; Vega Caro, L. y Vico Bosch, A. (2016).

Habilidades en Internet de mujeres estudiantes y su relación con la inclusión digital: Nuevas brechas digitales. Education in the Knowledge Society, vol. 17, n. 3, p. 29-48.

Jiménez Iglesias, E.; Garmendia, M. y Casado del Río, M.Á. (2015).

Percepción de los y las menores de la mediación parental respecto a los riesgos en internet. Revista Latina de Comunicación Social, n. 70, p. 49-68. En:

http://www.revistalatinacs.org/070/paper/1034-UP/04es.html 
Korupp, S. E. y Szydlik, M. (2005) “Causes and Trends of the Digital Divide”. European Sociological Review, vol. 21, n. 4, p. 409-422. Mayor Pérez, M. y Bacallao-Pino, L. (2015). Apropiaciones de las tic para la socialización por parte de personas con discapacidad auditiva. Un estudio de caso: Zaragoza. Cuadernos de trabajo social, 28(1), 101-111.

http://dx.doi.org/10.5209/rev_CUTS.2015.v28.n1.47154

Montes-Vozmediano, M., García-Jiménez, A. \& Menor-Sendra, J.

(2018). Teen videos on YouTube: Features and digital

vulnerabilities. [Los vídeos de los adolescentes en YouTube:

Características y vulnerabilidades digitales]. Comunicar, 54(1), 6169. https://doi.org/10.3916/C54-2018-06

Prensky, M. (2001). Digital Natives, Digital Immigrants. Part 1. On the Horizon, vol. 9, n. ${ }^{\circ}$ 5, p. 1-6.

Romero-Rodríguez, L.M.; Torres-Toukoumidis, A.; Pérez-Rodríguez, A. y Aguaded, I. (2016). Analfanautas y la cuarta pantalla:

ausencia de infodietas y de competencias mediáticas e informacionales en jóvenes latinoamericanos. Fonseca, Journal of Communication, n. 12, p. 11-25.

Serrano A. y Martínez, E, (2003). La Brecha Digital: Mitos y Realidades. México: UABC. En: http://www.labrechadigital.org/labrecha/LaBrechaDigital Mit osyRealidades.pdf

Vizcaíno-Laorga, R. Catalina-García, B. \& López de Ayala-López, M.C. (2019). Participation and commitment of young people in the digital environment. Uses of social networks and perception of their consequences. Revista Latina de Comunicación Social, 74, 554-572. doi: 10.4185/RLCS-2019-1345en

Walrave, M.; Vanwesenbeeck, I. \& Heirman, W. (2015). Connecting and protecting? Comparing predictors of self-disclosure and privacy settings use between adolescents and adults.

Cyberpsychology: Journal of Psychosocial Research on Cyberspace, vol. 6, n. 1. En:

https://journals.muni.cz/cyberpsychology/article/view/4259/ $\underline{3297}$ 


\title{
Participación, capital social y eficacia política: una encuesta comparativa a los universitarios de México y Chiles
}

\author{
Daniel Javier de la Garza Montemayor \\ Universidad Autónoma de Nuevo León (México) \\ danieldelagarza@gmail.com \\ Daniel Barredo Ibáñez \\ Universidad del Rosario (Colombia) \\ daniel.barredo@urosario.edu.co \\ Úrsula Freundt-Thurne \\ Universidad Peruana de Ciencias Aplicadas (Perú) \\ ursula.freundt@upc.pe
}

PARA CITAR: De la Garza, D.; Barredo Ibáñez, D. \& Freundt-Thurne, Ú. (2019). "Participación, capital social y eficacia política: una encuesta comparativa a los universitarios de México y Chile". En Barredo Ibáñez, D.; Cunha, M. R. \& Hidalgo Toledo, J. (Eds.) (2019). Jóvenes, participación y medios de comunicación digitales en América Latina <pp. 61-83>. La Laguna, España: Cuadernos Artesanos de Comunicación. DOI: $10.4185 / \mathrm{cac} 156$

\section{Resumen}

La participación política dentro y fuera de los medios sociales es un tema que ha sido abordado en los últimos años con especial interés, destacando especialmente los casos los casos de Chile y México. Para efectos de este estudio, en el caso chileno se realizaron 1100 encuestas a jóvenes universitarios, mientras que, en México, se aplicó el mismo instrumento a 1239 jóvenes. El objetivo central de la investigación es

\footnotetext{
${ }^{9}$ Este artículo es un producto del proyecto Esfera pública y participación ciudadana, con código PIN-2017-007, financiado por el fondo de proyectos de Gran Cuantía de la Universidad del Rosario (Colombia).
} 
realizar una comparación entre las percepciones de los jóvenes universitarios de ambos países sobre su concepto de participación política dentro y fuera de las redes sociales, así como su relación tanto con la construcción del capital social, como con el sentimiento de eficacia política.

\section{Palabras clave}

Internet, Participación política, Redes sociales, Eficacia política, Capital social.

\section{Introducción}

— S IMPENSABLE concebir la participación política principales enclaves de discusión. En ese sentido, a los espacios convencionales de deliberación política, se han unido esos otros espacios que emergen desde Internet, en la medida en que se generaliza el acceso a los dispositivos tecnológicos. En favor de esta reconfiguración del espacio público, son muchos los estudios que señalan la relación existente entre ambos modos de participación; por decirlo con otras palabras, aquellos usuarios que manifiestan una mayor apropiación de las calles, también suelen ser los que colaboran más activamente en las plataformas en línea (Lee et al., 2014; Barredo et al., 2015). Siguiendo esta corriente, para Deuk Hyun \& Kim (2015), el activismo en redes sociales puede contribuir a predecir el comportamiento político de los individuos. En buena medida, la efectividad de estas herramientas depende de la manera en que sean utilizadas y combinadas, de modo que se interrelacionen en los repertorios de movilización (Chen \& Chen, 2017). Aunque más allá de la efectividad, también existe evidencia de que los resultados pueden variar a lo largo del tiempo (Boulianne, 2009), en tanto que el empoderamiento tecnológico, no solo se da entre los usuarios, sino, asimismo, en otros actores, como las instituciones o los representantes políticos, entre otros.

Este estudio se ha construido con el objetivo de comparar el sentimiento de eficacia política, la construcción del capital social y su relación con la participación política en los jóvenes universitarios de 
dos interesantes casos de estudio. Por un lado, México, cuya democracia ha presentado, a lo largo de la historia, altos niveles de corrupción y de concentración del poder (Solís, 2016). Por el otro, Chile, una democracia representativa que empezó la transformación de las reglas de juego a finales de los años ochenta, gracias a la votación que finalizó con la dictadura (Orellana et al., 2015). Tal vez, debido a la juventud de su sistema democrático, según estos autores, aún falta por consolidar una mayor integración de electores protagónicos -como los jóvenes-, en las rutinas electorales. Tanto en México como en Chile, existe una gran desafección política, la cual tiene su correlato en los altos niveles de abstencionismo en los periplos electorales (Mijares, 2006; Sola \& Hernández, 2017).

Considerando que el objetivo central de la investigación consiste en analizar la participación política de las juventudes de México y Chile, dentro y fuera de las redes sociales, así como su rol en la construcción del capital social y la eficacia política, resulta importante recordar que, según Fukuyama (1999), es justamente el dinamismo del capital social una característica esencial para el sistema democrático y los mercados. $\mathrm{Y}$ es que para que las instituciones funcionen resulta fundamental la presencia de valores y normas, entre los que, según Rojas \& Marin (2006), la confianza constituye un elemento esencial.

Dicho de otro modo, y según los mismos autores, la confianza genera capital social y este, a su vez, activa el desarrollo económico. No en vano, Coleman (1988) reconoce en el capital social su carácter productivo, ya que posibilita el logro de objetivos que no podrían ser alcanzados de no existir este aspecto de manera informal, es decir, mediante la colaboración entre individuos (Fukuyama, 1999). De acuerdo a Rojas \& Marin (2006), el capital social puede clasificarse, según el tamaño de la comunidad, en: Micro (entre personas); Meso (entre organizaciones sociales) y Macro (organizaciones públicas y privadas superiores). Desde ese ángulo, existen ciertos medios que contribuyen, más que otros, a generar capital social. Según Barbosa, Fonseca, Amaro \& Pasqualotti (2018), el uso de Internet contribuye a generar capital social, especialmente entre determinados públicos, como por ejemplo entre los jóvenes, un grupo estratégico que será abordado en las páginas siguientes. 


\section{Marco teórico. Elementos para entender la participación política en México y Chile}

En términos más generales, aún desde antes del surgimiento de los medios sociales virtuales, ha sido notable la necesidad de profundizar en el estudio de las redes sociales que se generan en el entorno real. Al respecto, Ramos, Contreras \& García (2014) argumentan que el análisis de las redes sociales en México ha contado con avances notables, pero que la cooperación entre diferentes grupos de investigación, tanto nacionales como extranjeros, aún sigue siendo una tarea pendiente.

En el contexto mexicano, los estudios académicos sobre los efectos de los medios sociales en la participación política de los ciudadanos, comenzaron a tomar una mayor relevancia a partir del proceso electoral del año 2012 (Quiñónez, 2014). Esto se debe, en parte, a la coyuntura política que surgió en aquel proceso, pero también debido a que la ciberpolítica comenzó a manifestarse con mayor fuerza desde la irrupción de dicho fenómeno en ese año (Galindo \& González, 2013). La fuerza del movimiento \#YoSoy132, por ejemplo, se debió a que la intensa actividad en medios sociales se trasladó al ámbito público (Red, 2013). Más adelante, con la crisis política que significó la desaparición de los 43 normalistas en Ayotzinapa, las redes sociales se convertirían en una forma de organización para la protesta social espontánea (Fernández-Poncela, 2015).

Adicional a las coyunturas que se han mencionado, desde de la propia sociedad civil mexicana han surgido iniciativas en contra de la corrupción, que han tenido como base la difusión en medios sociales como Hagásmolo Bien, pero que han funcionado gracias a la participación real de diversos grupos que están orientados a un mismo fin (Peña, 2015). La discusión sobre asuntos públicos en medios sociales se ha vuelto cada vez más común. Al respecto, Lemus (2015) argumenta que algunos de los intelectuales más conocidos en México siguen publicando en medios tradicionales, pero los usuarios comentan o, incluso, impugnan sus argumentos a través de las redes sociales.

En el caso de la investigación de Cárdenas, Ballesteros \& Jara (2017) se compara el uso estratégico de los medios sociales en México, España y 
Chile por parte de los candidatos políticos. En los tres casos se pudieron identificar avances sustantivos en materia de gestión de redes sociales pero, sobre todo, en el caso de México y Chile, el uso de los mismos sigue siendo limitado. Esto último se debe a que los candidatos no parecen aprovechar las posibilidades que otorga Internet para interactuar de manera más eficaz con los ciudadanos.

En esto coincide el estudio realizado por Heras \& Díaz (2017), en el contexto de las elecciones del 2015 en el Estado de México. Los medios sociales fueron fundamentalmente utilizados por los candidatos para registrar a los seguidores y monitorear su propia visibilidad, pero en algunos casos incluso se tiene registrado que algunos candidatos relevantes de la oposición hicieron poco o un nulo uso de los medios sociales para efectos de comunicación política. Los resultados del estudio de Ballesteros \& Díez (2018) corroboran también esta tendencia, aunque, en este caso, aplicados al contexto español.

Por su parte, la participación política de los jóvenes en el contexto chileno cuenta como un hito con el plebiscito de 1988 (Orellana et al., 2015), en el cual se produjo una votación masiva, con el fin de rechazar a la dictadura, a favor de la democracia: unos cuatro de cada diez votantes, en esa elección, eran jóvenes (p. 121). En ese sentido, estos mismos autores indican que, desde aquella votación ya histórica, se ha ido registrando una paulatina falta de interés, de parte de los jóvenes, por la política, en la medida en que ha ido avanzando la democracia chilena. Esto puede explicarse por la falta de implementación de cambios reales y, adicionalmente, por la consolidación de un sistema que no se percibe como apegado a las expectativas de esta población.

Para Sola \& Hernández (2017), la abstención juvenil en Chile se identifica a partir de los débiles mecanismos de participación del sistema electoral de este país; además, estos autores aseguran que la desafección no caracteriza a todos los jóvenes por igual, sino que hay que tener en cuenta aspectos de relieve como el estatus socioeconómico, es decir, interpretando al trabajo anteriormente citado, es posible que, a menores ingresos, por ejemplo, encontremos una más pobre interacción e interés por lo público. 
Ante los altos niveles de abstencionismo, los medios de comunicación ejercen un rol clave en el incentivo de una mayor participación ciudadana. En el caso chileno, como explica Millaleo (2011), tras la dictadura, el sistema de medios se reconfiguró, quedando concentrados en unas pocas corporaciones. Por ello, con la emergencia de las redes sociales, aparecieron nuevos espacios de discusión política, en un país que presenta una de las mayores tasas de conexión a Internet de América Latina: en 2017, 9 de cada 10 chilenos accedían a la red, bien desde computadores personales, bien desde celulares (Subsecretaría de Telecomunicaciones, 2017).

La existencia de un sistema concentrado de medios, una democracia representativa con una dictadura como antecedente reciente, en conjunto con una alta conectividad, proponen los elementos adecuados para que se dé un uso estratégico a las redes sociales. Quizá, por todo ello, ha habido algunos interesantes casos de movilización ciudadana mediados por la tecnología. Uno de ellos es la llamada "Revolución Pingüina", una masiva participación estudiantil que, durante 192 días, se encargó de evidenciar ante la opinión pública los problemas de la educación pública en el país (Millaleo, 2011). Como resultado de este ejercicio democrático, el autor citado recuerda que el gobierno de la presidenta Bachelet tuvo que proponer una agenda de iniciativas para mejorar la calidad de la educación. Otro caso relevante de la ciberpolítica chilena sucedió en el 2011, cuando durante siete meses los jóvenes estudiantes chilenos protestaron en favor de una mejor educación pública (Vera, 2011), siendo la principal movilización, según esta autora, de las que se han dado tras el fin de la dictadura. Durante el llamado "Invierno chileno", los jóvenes participantes emplearon un repertorio basado en la combinación de herramientas en línea y fuera de línea (Cabalin, 2014), que fueron vitales para alcanzar una movilización que, por ejemplo, llegó a reunir a unos 100.000 estudiantes en una sola marcha, así como para generar cambios en la esfera política -no en vano tuvo que dimitir el Ministro de Educación-

Pero a pesar de estos casos -que revelan un uso efectivo de las herramientas tecnológicas-, hay trabajos que aseguran que, en el electorado chileno, el consumo de las redes sociales, más que provocar una mayor deliberación pública, "refuerza la predisposición" de los 
electores (Navia \& Paz, 2017, p. 83), de forma similar a la evidencia reunida en otros contextos, como el ecuatoriano (Barredo et al., 2015). Sin embargo, no todos los autores concuerdan con esta opinión; por ejemplo, De Jesús, López \& Ortiz (2017) sostienen que existe una correlación entre el consumo de contenidos difundidos en las redes sociales, y unos mayores niveles de participación de los jóvenes.

\subsection{Eficacia y participación política}

En el caso del constructo del sentimiento de eficacia política, existen dos planteamientos que son complementarios, pero que deben de analizarse por separado: eficacia política externa e interna. En el caso de la primera, Min (2006) la definía como la capacidad auto percibida de los individuos para generar conciencia, influir en otros y contribuir a generar un cambio en materia política. Mientras que, en el caso de la eficacia política interna, nos remitimos a un sentimiento en cuanto a que el individuo se considera capaz de participar con éxito en los procesos políticos (Balch, 1974).

En el caso de la investigación de Riaz \& Javaid (2017), se buscó medir el nivel de eficacia política de los jóvenes de Madrassa. Este trabajo se proyectó mediante un método cuantitativo, a partir de una muestra de 400 estudiantes. Los resultados fueron que aquellos que vivían en las zonas urbanas presentaban un mayor índice de eficacia política que aquellos quienes habitaban en las zonas rurales. Los autores, asimismo, percibieron la existencia de otras variables que incidían en el nivel de eficacia política, como el nivel socioeconómico o el educativo. A mayor nivel educativo, el sentimiento de eficacia disminuía. De igual manera, los estudiantes que eran hijos de obreros presentaron una mayor propensión a participar en política que los que tenían padres empresarios.

En el caso de China, los académicos Zeng, Chen \& Li (2018) estudiaron la relación entre algunas experiencias injustas, sus intereses, y la eficacia política, con su participación individual en asuntos colectivos. La información se obtuvo en este trabajo mediante una encuesta que realizó el Departamento de Sociología de la Universidad Renmin de China. En este caso, se encontró que el nivel educativo tenía 
un impacto negativo en su implicación cívica. Sin embargo, cuando los encuestados reconocían haber padecido alguna experiencia injusta, se producía el efecto contrario. No obstante, el sentimiento de eficacia política interna tenía una incidencia positiva en la participación política.

En Malasia, Tin \& Wan (2018) realizaron una investigación sobre la influencia de los medios de comunicación en la conversación política de los estudiantes en Malasia, también, como en el caso anterior, mediante una encuesta. La mayoría de los estudiantes se informaba a través de medios electrónicos, como YouTube o los diarios digitales. Entre los resultados más relevantes, los alumnos demostraron tener una mayor confianza en participar en acciones políticas, que en mantener discusiones con otros sobre el mismo tema. En otras palabras, demostraron tener una mayor eficacia política externa, que interna.

Sobre el mismo tema, Tully \& Vraga (2018) examinaron la relación entre la alfabetización de los medios de comunicación y la eficacia política. Este estudio fue cualitativo, principalmente dirigido a adultos a quienes se les cuestionó sobre el conocimiento que consideraban que tenían sobre las noticias y la percepción sobre el nivel de información sobre acontecimientos importantes y su relación con la eficacia política. En este caso, los investigadores se encontraron con que algunos de los participantes en el estudio consideraban que tenían conocimiento sobre las noticias, pero no se sentían especialmente seguros de participar en asuntos relacionados con la política.

El estudio de Arens \& Watermann (2017) se centró en alumnos de secundaria; en este trabajo, se buscó reconocer si existía una relación entre el interés en la política y el sentimiento de eficacia política, considerando las diferencias de género. Al respecto, la investigación demostró que la eficacia política aumentaba en la misma proporción en que era más elevado el grado que cursaban los estudiantes, mientras que también se debe resaltar que, de acuerdo a este estudio, la eficacia política y la información sobre esta materia tuvieron una relación positiva. Debido a los resultados enunciados anteriormente, los investigadores recomiendan atender la manera en que los alumnos son 
informados, ya que, con el fortalecimiento de la eficacia, puede contribuirse a generar un mayor interés en temas políticos.

En el contexto europeo, Mcevoy (2016) realizó un estudio para medir la relación entre la eficacia política con el apoyo a la Unión Europea a partir de la crisis económica del 2008. Este estudio se realizó con base en el Eurobarómetro, en donde se tomaron los datos pertenecientes a quienes formaban parte de los Estados miembros de la Unión. Los resultados demostraron que el nivel de eficacia política externa fue fundamental, debido a que su opinión se sustenta en los resultados que la Unión puede proveer a largo plazo, así como la respuesta que puede tener para los diversos intereses políticos que puedan existir.

La investigación de Serek, Machackova \& Macek (2017) buscó indagar sobre la relación existente entre la eficacia política tanto interna como externa, con la participación política. En este sentido, los autores encontraron que la participación en movilizaciones puede predecir cambios en la eficacia política interna, mientras que otras formas de participación convencional no tenían efectos en este sentimiento. Por otro lado, no se encontró un efecto predictivo entre la participación política convencional y la eficacia externa, mientras que, en el caso de la movilización social, observaron efectos adversos.

En el trabajo de Reichert (2016), el investigador tomó la eficacia política como variable mediadora entre el conocimiento y la participación política. En dicho estudio se descubrió, en términos generales, que la eficacia política sí era un factor moderador entre ambas, debido a que, en principio, no se explica el comportamiento político con base en el conocimiento. Pero la eficacia política se correlaciona de manera positiva con el conocimiento político, por lo que la eficacia termina incidiendo de manera significativa tanto en la participación convencional, como en la no convencional. Por ello, la investigación concluye que la eficacia política tiene un efecto positivo en la participación política.

En los Estados Unidos, Wolak (2018) aborda el constructo de la eficacia política desde el punto de vista de las acciones de gobierno y cómo son valoradas por parte de los ciudadanos. Este estudio se realizó 
en 50 Estados de ese país. En términos generales, en los resultados se establece que, en la medida en que los gobiernos regionales dan respuesta a los ciudadanos, éstos terminan por aumentar su sentimiento de eficacia. Y, asimismo, en la medida en que los representantes se comportan como lo esperan sus electores, los segundos consideran que tienen una manera eficaz de influir en las acciones de gobierno.

\section{Metodología}

Esta investigación, de alcance descriptivo, se basó en una encuesta, un método cuantitativo con el que se busca codificar las percepciones de un grupo de personas. En total, se realizaron 1100 encuestas en el caso chileno con jóvenes universitarios, mientras que en el caso de México se aplicó el mismo estudio a 1239 jóvenes. En el caso de México, se contó con la participación de alumnos de diversas regiones del país como Nuevo León, Estado de México, Sonora, Oaxaca y Durango. Mientras que en el caso de Chile los participantes fueron principalmente de la ciudad de Concepción. En ambos casos, la muestra fue por conveniencia. En la aplicación de la encuesta se contó con la participación de profesores, personal administrativo y grupos estudiantiles que participaron en la difusión.

La principal condición para participar en el estudio fue la de ser un estudiante universitario activo, de pregrado. En este sentido, ambas muestras tomaron en cuenta a estudiantes vigentes de diferentes semestres, en específico aquellos que cursaban alguna carrera relacionada con las ciencias sociales. En la aplicación se utilizó la herramienta de Google Forms.

En el cuestionario se tomaron preguntas de diversos estudios en torno a los siguientes temas: participación política en línea (Gil de Zúñiga \& Veenstra, Vraga y Shah, 2010, Vesnic-Alujevic, 2012 y Oser, Hooghe y Marien, 2013), sentimiento de eficacia política (Kushin \& Yamamoto, 2010) y capital social (Pishghadam, Nohani y Zabihi, 2011). Estas son las tres dimensiones que son comparadas para efectos del presente capítulo. 


\section{Resultados}

En primer lugar, al comparar la eficacia política percibida por los estudiantes consultados en México y en Chile, encontramos algunas similitudes: en ambos casos, los encuestados están totalmente de acuerdo en que la participación a través del voto o, en general, en el ámbito político, puede conllevar a algún tipo de cambio:

Tabla 1. Eficacia política percibida por los estudiantes consultados en México

\begin{tabular}{llllll}
\hline & $\begin{array}{l}\text { Respuesta } \\
\text { mayoritaria }\end{array}$ & $\begin{array}{l}\text { Porcentaje } \\
\text { Total }\end{array}$ & $\boldsymbol{F}$ & $\boldsymbol{M}$ & $\boldsymbol{D E}$ \\
\hline Mi voto hace la diferencia & $\begin{array}{l}\text { Totalmente } \\
\text { acuerdo }\end{array}$ & $45.6 \%$ & 565 & 4.01 & 1.13 \\
\hline $\begin{array}{l}\text { La información que } \\
\text { comparto en redes } \\
\text { sociales es de calidad }\end{array}$ & Intermedio & $44.2 \%$ & 546 & $\mathbf{3 . 4 1}$ & 1.00 \\
\hline $\begin{array}{l}\text { La información que } \\
\text { comparto en redes } \\
\text { sociales puede contribuir }\end{array}$ & De acuerdo & $32 \%$ & 397 & $\mathbf{3 . 6 8}$ & 1.05 \\
\hline $\begin{array}{l}\text { Puedo hacer la diferencia } \\
\text { si participo en política }\end{array}$ & $\begin{array}{l}\text { Totalmente } \\
\text { acuerdo }\end{array}$ & $31.8 \%$ & 394 & $\mathbf{3 . 7 9}$ & 1.09 \\
\hline $\begin{array}{l}\text { Tengo la manera de influir } \\
\text { en lo que hace el gobierno }\end{array}$ & Intermedio & $36.7 \%$ & 455 & 3.13 & 1.17 \\
\hline $\begin{array}{l}\text { Tengo la manera de influir } \\
\text { en lo que hacen los } \\
\text { partidos políticos }\end{array}$ & Intermedio & $36.1 \%$ & 446 & 2.94 & 1.18 \\
\hline $\begin{array}{l}\text { Tengo la manera de influir } \\
\text { en lo que hacen los } \\
\text { candidatos }\end{array}$ & Intermedio & $38 \%$ & 471 & 3.00 & 1.17 \\
\hline $\begin{array}{l}\text { Puedo contribuir a que } \\
\text { otros cambien de opinión }\end{array}$ & Intermedio & $37 \%$ & 458 & 3.32 & 1.15 \\
\hline
\end{tabular}

El valor mínimo es de 1 y el valor máximo es de 5 . Existen 5 valores: Totalmente en desacuerdo, Desacuerdo, Ni de acuerdo ni en desacuerdo, De acuerdo y Totalmente de acuerdo.

Como se muestra en la tabla anterior, se puede apreciar que, en términos de eficacia política, los estudiantes encuestados en México manifestaron que estaban más cerca del acuerdo en tres aseveraciones: que la información que comparten es de calidad $(M=3.41 \mathrm{DE}=1.00)$, 
que la información que comparten puede contribuir a que la gente cambie de opinión $(M=3.68, D E=1.05)$, y que pueden hacer la diferencia si participan en política $(M=3.79, D E=1.09$.), además de que hubo un acuerdo mayoritario con la frase "Mi voto hace la diferencia" $(M=4.01, D E=1.13)$. En esto coincidieron con los estudiantes chilenos; de hecho, según la tabla 2, fueron las mismas frases que resultaron por encima de la media: la importancia del voto $(M=4.09, D E=1.13)$, la calidad de la información $(M=3.26, D E=1.06)$, la posibilidad de influir $(M=3.57, D E=1.17)$, y la capacidad auto percibida en poder contribuir a un cambio real $(M=3.56, D E=1.27)$ :

\section{Tabla 2. Eficacia política percibida por los estudiantes consultados en Chile}

\begin{tabular}{lccccc}
\hline & $\begin{array}{c}\text { Respuesta } \\
\text { mayoritaria }\end{array}$ & $\begin{array}{c}\text { Porcentaje } \\
\text { Total }\end{array}$ & $\boldsymbol{F}$ & $\boldsymbol{M}$ & $\mathbf{D E}$ \\
\hline Mi voto hace la diferencia & $\begin{array}{c}\text { Totalmente de } \\
\text { acuerdo }\end{array}$ & $49.7 \%$ & 525 & $\mathbf{4 . 0 9}$ & 1.13 \\
\hline $\begin{array}{l}\text { La información que } \\
\text { comparto en redes sociales } \\
\text { es de calidad }\end{array}$ & Intermedio & $44.5 \%$ & 470 & $\mathbf{3 . 2 6}$ & 1.06 \\
\hline $\begin{array}{l}\text { La información que } \\
\text { comparto en redes sociales } \\
\text { puede contribuir }\end{array}$ & De acuerdo & $34.4 \%$ & 364 & $\mathbf{3 . 5 7}$ & 1.17 \\
\hline $\begin{array}{l}\text { Puedo hacer la diferencia si } \\
\text { participo en política }\end{array}$ & $\begin{array}{c}\text { Totalmente de } \\
\text { acuerdo }\end{array}$ & $29.2 \%$ & 309 & $\mathbf{3 . 5 6}$ & 1.27 \\
\hline $\begin{array}{l}\text { Tengo la manera de influir } \\
\text { en lo que hace el gobierno }\end{array}$ & Intermedio & $27.5 \%$ & 291 & 2.56 & 1.26 \\
\hline $\begin{array}{l}\text { Tengo la manera de influir } \\
\text { en lo que hacen los partidos } \\
\text { políticos }\end{array}$ & $\begin{array}{c}\text { Totalmente en } \\
\text { desacuerdo }\end{array}$ & $34.1 \%$ & 360 & 2.29 & 1.19 \\
$\begin{array}{l}\text { Tengo la manera de influir } \\
\text { en lo que hacen los } \\
\text { candidatos }\end{array}$ & $\begin{array}{c}\text { Totalmente en } \\
\text { desacuerdo }\end{array}$ & $29.8 \%$ & 315 & 2.42 & 1.21 \\
\hline $\begin{array}{l}\text { Puedo contribuir a que otros } \\
\text { cambien de opinión }\end{array}$ & Intermedio & $32.4 \%$ & 342 & 2.92 & 1.25 \\
\hline
\end{tabular}

El valor mínimo es de 1 y el valor máximo es de 5 . Existen 5 valores: Totalmente en desacuerdo, Desacuerdo, Ni de acuerdo ni en desacuerdo, De acuerdo y Totalmente de acuerdo. 
Sin embargo, encontramos una diferencia clave entre ambos grupos de estudiantes. Por un lado, los encuestados en México acordaron un consenso sobre un nivel intermedio percibido en la influencia en lo que hace el gobierno $(M=3.13, D E=1.17)$, los partidos políticos $(M=2.94$, $D E=1.18)$, los candidatos $(M=3.00, D E=1.17)$, o a que otros cambien de opinión $(M=3.32, D E=1.15)$. Por el otro lado, los universitarios chilenos están en total desacuerdo con que pueden influir en los políticos $(M=2.29, D E=1.19)$, o los candidatos $(M=2.42, D E=1.21)$, aunque sí coincidieron en una percepción intermedia sobre la influencia en lo que hace el gobierno $(M=2.56, D E=1.26)$, o para que otros cambien de opinión $(M=2.92, D E=1.25)$.

Con respecto del capital social, en el caso de los jóvenes mexicanos encuestados, las opciones con las que se mostraron de acuerdo o totalmente de acuerdo fueron con que hablan con sus padres $(M=4.22$, $D E=1.02)$, ven a sus hermanos $(M=3.81, D E=1.48)$, o a sus amigos semanalmente $(M=4.14, D E=1.11) \quad y$, en menor medida, la participación en actividades para jóvenes $(M=3.75, D E=1.06)$ :

\section{Tabla 3. Capital social percibido por los estudiantes consultados en México}

\begin{tabular}{llllll}
\hline & $\begin{array}{l}\text { Respuesta } \\
\text { mayoritaria }\end{array}$ & $\begin{array}{l}\text { Porcentaje } \\
\text { Total }\end{array}$ & $\boldsymbol{F}$ & $\boldsymbol{M}$ & $\boldsymbol{D E}$ \\
\hline Hablo con mis padres & $\begin{array}{l}\text { Totalmente de } \\
\text { acuerdo }\end{array}$ & $53.2 \%$ & 658 & $\mathbf{4 . 2 2}$ & 1.02 \\
\hline $\begin{array}{l}\text { Participo en actividades para } \\
\text { jóvenes }\end{array}$ & De acuerdo & $30.7 \%$ & 379 & $\mathbf{3 . 7 5}$ & 1.06 \\
\hline $\begin{array}{l}\text { Mis padres se involucran en } \\
\text { mis actividades }\end{array}$ & Intermedio & $29.2 \%$ & 362 & 3.48 & 1.18 \\
\hline $\begin{array}{l}\text { Veo a mis hermanos } \\
\text { semanalmente }\end{array}$ & $\begin{array}{l}\text { Totalmente de } \\
\text { acuerdo }\end{array}$ & $50.7 \%$ & 627 & $\mathbf{3 . 8 1}$ & 1.48 \\
\hline $\begin{array}{l}\text { Veo a mis amigos } \\
\text { semanalmente }\end{array}$ & $\begin{array}{l}\text { Totalmente de } \\
\text { acuerdo }\end{array}$ & $51.8 \%$ & 640 & $\mathbf{4 . 1 4}$ & 1.11 \\
\hline $\begin{array}{l}\text { Tengo lazos con la comunidad } \\
\text { Las redes sociales contribuyen } \\
\text { a generar confianza }\end{array}$ & Intermedio & $36 \%$ & 446 & 3.46 & 1.13 \\
\hline $\begin{array}{l}\text { Las redes sociales contribuyen } \\
\text { a disminuir confianza }\end{array}$ & Intermedio & $35.1 \%$ & 434 & 3.51 & 1.07 \\
\hline
\end{tabular}




\begin{tabular}{llllll}
\hline $\begin{array}{l}\text { Incrementan la confianza entre } \\
\text { gente que no se conoce }\end{array}$ & Intermedio & $38.5 \%$ & 477 & 3.28 & 1.10 \\
$\begin{array}{l}\text { Tengo fuertes lazos con mis } \\
\text { contactos }\end{array}$ & Intermedio & $36.1 \%$ & 446 & 3.04 & 1.12 \\
\hline $\begin{array}{l}\text { Confío igual en amigos offline y y } \\
\text { online }\end{array}$ & $\begin{array}{l}\text { Totalmente } \\
\text { en desacuerdo }\end{array}$ & $26.5 \%$ & 328 & 2.58 & 1.27 \\
\hline \multicolumn{1}{l}{ El valor mínimo es de 1 y el valor máximo es de 5. Existen 5 valores: }
\end{tabular}

El valor mínimo es de 1 y el valor máximo es de 5 . Existen 5 valores:

Totalmente en desacuerdo, Desacuerdo, Ni de acuerdo ni en desacuerdo, De acuerdo y Totalmente de acuerdo.

Por su parte, los universitarios chilenos coincidieron en sus percepciones con los mexicanos. Las opciones con las que se mostraron de acuerdo o totalmente de acuerdo fueron hablar con sus padres $(M=4.31, D E=0.93)$, ver a sus hermanos $(M=3.57, D E=1.60)$, o a sus amigos semanalmente $(M=4.01, D E=1.16)$ y, en menor medida, la participación en actividades para jóvenes $(M=3.53, D E=1.19)$ :

\section{Tabla 4. Capital social percibido por los estudiantes consultados en Chile}

\begin{tabular}{lccccc}
\hline & $\begin{array}{c}\text { Respuesta } \\
\text { mayoritaria }\end{array}$ & $\begin{array}{c}\text { Porcentaje } \\
\text { Total }\end{array}$ & $\boldsymbol{F}$ & $\boldsymbol{M}$ & $\boldsymbol{D E}$ \\
\hline Hablo con mis padres & $\begin{array}{c}\text { Totalmente de } \\
\text { acuerdo }\end{array}$ & $55.3 \%$ & 584 & 4.31 & .93 \\
\hline $\begin{array}{l}\text { Participo en actividades } \\
\text { para jóvenes }\end{array}$ & De acuerdo & $31.5 \%$ & 333 & $\mathbf{3 . 5 3}$ & 1.19 \\
\hline $\begin{array}{l}\text { Mis padres se involucran } \\
\text { en mis actividades }\end{array}$ & Intermedio & $28.2 \%$ & 298 & 2.88 & 1.23 \\
\hline $\begin{array}{l}\text { Veo a mis hermanos } \\
\text { semanalmente }\end{array}$ & $\begin{array}{c}\text { Totalmente de } \\
\text { acuerdo }\end{array}$ & $47.2 \%$ & 499 & $\mathbf{3 . 5 7}$ & 1.60 \\
\hline $\begin{array}{l}\text { Veo a mis amigos } \\
\text { semanalmente }\end{array}$ & $\begin{array}{c}\text { Totalmente de } \\
\text { acuerdo }\end{array}$ & $46.2 \%$ & 488 & 4.01 & 1.16 \\
\hline $\begin{array}{l}\text { Tengo lazos con la } \\
\text { comunidad }\end{array}$ & Intermedio & $31.2 \%$ & 330 & 3.08 & 3.08 \\
\hline $\begin{array}{l}\text { Las redes sociales } \\
\text { contribuyen a generar } \\
\text { confianza }\end{array}$ & Intermedio & $34.2 \%$ & 362 & 2.73 & 2.73 \\
\hline $\begin{array}{l}\text { Las redes sociales } \\
\text { contribuyen a disminuir } \\
\text { confianza }\end{array}$ & Intermedio & $31.9 \%$ & 337 & 2.67 & 2.67 \\
\hline
\end{tabular}




\begin{tabular}{lccccc}
\hline $\begin{array}{l}\text { Incrementan la confianza } \\
\text { entre gente que no se } \\
\text { conoce }\end{array}$ & Intermedio & $32.4 \%$ & 342 & 2.95 & 2.95 \\
\hline $\begin{array}{l}\text { Tengo fuertes lazos con } \\
\text { mis contactos }\end{array}$ & Intermedio & $29.2 \%$ & 309 & 2.46 & 2.46 \\
\hline $\begin{array}{l}\text { Confío igual en amigos } \\
\text { offline y online }\end{array}$ & $\begin{array}{c}\text { Totalmente en } \\
\text { desacuerdo }\end{array}$ & $49.8 \%$ & 526 & 1.91 & 1.91 \\
\hline
\end{tabular}

El valor mínimo es de 1 y el valor máximo es de 5 . Existen 5 valores: Totalmente en desacuerdo, Desacuerdo, Ni de acuerdo ni en desacuerdo, De acuerdo y Totalmente de acuerdo.

Pero además de coincidir en las opciones más relevantes, también observamos un consenso con respecto de una de las opciones con las que se mostraron en desacuerdo: los estudiantes universitarios de un país y otro no confían por igual en los amigos offline y online, siendo más acentuado el desacuerdo en Chile $(M=1.91, D E=1.91)$, que en México $(M=2.58, D E=1.27)$. Por su parte, las opciones vinculadas a la participación en redes sociales, así como a la participación comunitaria, alcanzaron consensos alrededor de las respuestas neutras.

Al preguntar a los estudiantes universitarios de México sobre las opciones de participación política, se observaron unos escasos niveles de interacción, fruto posiblemente de un bajo nivel de involucramiento político. Así, como se verá en la Tabla 5 a continuación, la opción que registró un consenso más alto -alrededor, eso sí, de la respuesta poco-, fue la participación en discusiones $(M=1.90, D E=1.64)$ :

Tabla 5. Participación política en redes sociales de los estudiantes consultados en México

\begin{tabular}{lcccc}
\hline & $\begin{array}{c}\text { Respuesta } \\
\text { mayoritaria }\end{array}$ & $\begin{array}{c}\text { Porcentaje } \\
\text { Total }\end{array}$ & $\boldsymbol{M}$ & $\boldsymbol{D E}$ \\
\hline $\begin{array}{l}\text { Busco información sobre } \\
\text { política }\end{array}$ & Algo & $36.6 \%$ & $\mathbf{2 . 0 8}$ & 1.11 \\
$\begin{array}{l}\text { Leo contenido humorístico } \\
\text { Comparto contenido }\end{array}$ & Algo & $33.2 \%$ & 1.68 & 1.28 \\
humorístico & Algo & $26.8 \%$ & 1.68 & 1.28 \\
$\begin{array}{l}\text { Leo discusiones } \\
\text { Participo en discusiones }\end{array}$ & Algo & $33.7 \%$ & $\mathbf{2 . 1 7}$ & 1.11 \\
& Poco & $27.4 \%$ & 1.90 & 1.64
\end{tabular}




\begin{tabular}{|c|c|c|c|c|}
\hline $\begin{array}{l}\text { Veo un video de contenido } \\
\text { político }\end{array}$ & Algo & $33.4 \%$ & 2.20 & 1.12 \\
\hline $\begin{array}{l}\text { Comparto un video de } \\
\text { contenido político }\end{array}$ & Algo & $25.6 \%$ & 1.62 & 1.26 \\
\hline $\begin{array}{l}\text { Publico opiniones sobre } \\
\text { política }\end{array}$ & Nada & $34.9 \%$ & 1.27 & 1.22 \\
\hline Doy un like a un comentario & Algo & $24.9 \%$ & 1.94 & 1.34 \\
\hline $\begin{array}{l}\text { Posteo información sobre } \\
\text { política }\end{array}$ & Nada & $36.6 \%$ & 1.16 & 1.13 \\
\hline Sigo cuentas de políticos & Nada & $26.9 \%$ & 1.61 & 1.31 \\
\hline $\begin{array}{l}\text { Sigo cuentas de periodistas, } \\
\text { líderes de opinión }\end{array}$ & Algo & $26.8 \%$ & 1.78 & 1.3 \\
\hline $\begin{array}{l}\text { Contesto comentarios de } \\
\text { políticos }\end{array}$ & Nada & $58.1 \%$ & .73 & 1.03 \\
\hline $\begin{array}{l}\text { Firmo peticiones sobre asuntos } \\
\text { colectivos }\end{array}$ & Nada & $40.1 \%$ & 1.19 & 1.22 \\
\hline
\end{tabular}

El valor mínimo es de 0 , y el valor máximo es de 4. Existen 5 valores: Nada, Poco, Algo, Mucho y Bastante.

De igual manera, en el caso de los estudiantes chilenos predominó la desafección política en sus respuestas: al revisar la Tabla 6 , se percibe el desencanto de los jóvenes por participar activamente en este contexto. Resulta muy llamativo que los principales consensos se hayan construido alrededor de los ítems nada y algo. En ese sentido, estudios como el de Navia \& Paz (2017) señalan que, en Chile, las redes sociales se emplean, sobre todo, para reforzar las posiciones políticas previas de los usuarios:

Tabla 6. Participación política en redes sociales de los estudiantes consultados en Chile

\begin{tabular}{lcccc}
\hline & $\begin{array}{c}\text { Respuesta } \\
\text { mayoritaria }\end{array}$ & $\begin{array}{c}\text { Porcentaje } \\
\text { Total }\end{array}$ & $\boldsymbol{M}$ & $\boldsymbol{D E}$ \\
\hline $\begin{array}{l}\text { Busco información sobre } \\
\text { política }\end{array}$ & Algo & 30.4 & 1.89 & 1.24 \\
$\begin{array}{l}\text { Leo contenido humorístico } \\
\text { Comparto contenido }\end{array}$ & Algo & 26.8 & $\mathbf{2 . 0 3}$ & 1.28 \\
humorístico & Nada & 32.2 & 1.54 & 1.40 \\
$\begin{array}{l}\text { Leo discusiones } \\
\text { Participo en discusiones }\end{array}$ & Algo & 30.1 & $\mathbf{2 . 0 2}$ & 1.25 \\
& Nada & 42.8 & 1.12 & 1.22
\end{tabular}


Veo un video de contenido

político

$\begin{array}{llll}\text { Algo } & 28.1 & 1.79 & 1.24\end{array}$

Comparto un video de contenido político

Nada

51.5

$.95 \quad 1.19$

Publico opiniones sobre

política

Nada

52

$.99 \quad 1.26$

Doy un like a un

comentario

Nada

25.5

1.94

1.48

Posteo información sobre

política

Nada

56.3

.81

1.09

Sigo cuentas de políticos

Nada

51.9

1.01

1.27

Sigo cuentas de

periodistas, líderes de

Nada

41.2

1.19

1.26

opinión

Contesto comentarios de

políticos

Nada

71.1

.47

.85

Firmo peticiones sobre

asuntos colectivos

Nada

37.6

$1.27 \quad 1.26$

El valor mínimo es de 0 , y el valor máximo es de 4. Existen 5 valores: Nada, Poco, Algo, Mucho y Bastante.

Precisamente, en Chile se ha ido produciendo un descenso de jóvenes en rutinas políticas tan importantes como las elecciones, como explican Orellana et al. (2015), un hecho que puede estar relacionado con la institucionalización de la democracia representativa liberal. Asimismo, estudios como el de Sola \& Hernández (2017) señalan que los jóvenes chilenos se caracterizan por formas convencionales de participación, más que por mecanismos de participación en línea.

\section{Discusión y conclusiones}

Curiosamente, la eficacia política percibida por los estudiantes chilenos con respecto de los políticos o los candidatos es menor que en el caso de los mexicanos. Esto no significa necesariamente que la democracia mexicana sea más profunda y participativa que la de Chile. Por el contrario, el concepto de participación podría estar más desarrollado entre los estudiantes chilenos encuestados, que, para los mexicanos, que no tienen claro si pueden influir en la política de ese país. 
En un estudio realizado por Roldán, Sustanonpaiboon \& Burkhard (2017), se subraya que los usuarios establecen relaciones de confianza, fortaleciendo el capital social, en la medida en que optan por interactuar entre ellos. Sin embargo, en los grupos abordados, esta interacción se ejerce en dos ámbitos coincidentes, los cuales pueden ejercer una influencia decisiva en esta población: la familia, por un lado, y el entorno social fuera de línea, por el otro. Al contrario de lo que podría pensarse, no hemos percibido un efecto tan grande procedente de la participación comunitaria, ni tampoco en las redes sociales, que en estos dos ámbitos. De hecho, esta conclusión se apuntala con otro interesante resultado: ambos grupos de jóvenes no confían por igual en sus amigos offline y online, es decir, hay diferencias actitudinales percibidas en unos y otros amigos. De esta manera, los jóvenes encuestados entrarían dentro de una definición relacionada a la de usuarios pasivos en línea, más que a activos productores y consumidores de contenidos, algo que ya avistamos en un estudio precedente (Barredo et al., 2018). En el caso de los jóvenes chilenos, estudios como el de Sola \& Hernández (2017) sostienen que la participación se mediatiza desde rutinas convencionales, y no tanto digitales. Asimismo, los resultados encajan en lo que Putman (1995) denomina el linking o capital social de vinculación.

La pasividad se vincula con otro factor relevante, como es la desafección política. Los estudiantes universitarios de México y Chile, según presentamos en las páginas anteriores, declinan en gran medida en la participación en los asuntos políticos de sus países. En el primer caso, en México, esto podría explicarse por presentar una democracia de carácter autoritario (Solís, 2016), unos medios de comunicación concentrados fundamentalmente en las dos grandes televisoras Televisa y TV Azteca-, y unos altos niveles de desafección, visibles en, por ejemplo, los altos niveles de abstención electoral (Mijares, 2006). En Chile, por su parte, la falta de participación en las elecciones -con un descenso de votantes jóvenes en las últimas dos décadas (Orellana et al., 2015)-, alerta también sobre el desencanto con el sistema democrático.

Desde nuestro punto de vista, resulta problemático que un grupo estratégicamente informado, como es el que está conformado por 
jóvenes universitarios, no desee participar políticamente en los asuntos de sus países. Con relación a ello, Kim (2018) concluyó en su investigación que la interacción a través de las redes sociales en un grupo social, puede estimular un mayor comportamiento colectivo. En ese sentido, consideramos prioritario que los sistemas electorales de ambos países propongan medidas de inclusión en línea, en aras de efectivizar una mayor participación de los jóvenes.

\section{Referencias}

Arens, A. \& Watermann, R. (2017). Political Efficacy in Adolescence:

Development, Gender Differences, and Outcome Relations.

Developmental Psychology, 53 (5), 933-948.

Balch, G. (1974). Multiple Indicators in Survey Research: The

Concept 'Sense of Political Efficacy. Political Methodology, 1(2), 143.

Ballesteros, C. \& Díez, M. (2018). We need to talk. Engagement 2.0 on Facebook during the Spanish campaign of December 20, 2015. Communication \& Society, 31, 169-193. Doi:

10.15581/003.31.1.169-193.

Barbosa, B., Fonseca, J., Amaro, F. \& Pasqualotti, A. (2018). Social capital and Internet use in an age-comparative perspective with a focus on later life. Plos One, 13(2), 1-27.

Barredo Ibáñez, D.; Arcila, C.; Arroyave, J. \& Silva, R. (2015). Influence of Social Networks in the Decision to Vote: An Exploratory Survey on the Ecuadorian Electorate. International Journal of E-Politics, 6(4), 15-34.

Barredo Ibáñez, D.; De la Garza, D.; Freundt-Thurne, U; Pinto, K. T. \& Días, D. L. (2018). Cuestionando la existencia del prosumer en Iberoamérica. Un estudio sobre los universitarios de Colombia, Perú, Chile y España. LETRAL, 20, 183-205.

Bernhard, U. \& Dohle, M. (2015). Corrective or Confirmative Actions? Political Online Participation as a Consequence of Presumed Media Influences in Election Campaigns. Journal of Information Technology and Politics, 12, 285-305. Doi: 10.1080119331681.2015.1048918.

Boulianne, S. (2009). Does Internet Use Affect Engagement? A MetaAnalysis of Research. Taylor \& Francis Group, LLC, 26, 193-211. Doi: 10.1080/10584600902854363. 
Cabalin, C. (2014). Estudiantes conectados y movilizados: El uso de Facebook en las protestas estudiantiles en Chile. Comunicar, 43(XXII), 25-33.

Cardenas, A., Ballesteros, C. \& Jara, R. (2017). Social networks and electoral campaigns in Latin America. A comparative analysis of the cases of Spain, Mexico and Chile. Cuadernos.Info, 41, 227242. https://doi.org/10.7764/cdi.41.1259

Chan, M. (2016). Social Network Sites and Political Engagement: Exploring the Impact of Facebook Connections and Uses on Political Protest and Participation. Mass Communication and Society, 19, 430-450. Doi: 10.1080/15205436.2016.1161803.

Chen, Z. \& Chen M. (2017). Motivations for Social Media Use an Impact on Political Participation in China: a Cognitive and Communication Mediation Approach. Mary Ann Liebert Inc., 20(2), 83-89. Doi: 10.1089/cyber2016.0174.

Coleman, J.S. (1988). Social Capital in the Creation of Human Capital. The American Journal of Sociology, 94, S95-S120

De Jesús, F.; López, R. \& Ortiz, G. (2017). Redes sociales digitales y participación política de jóvenes universitarios de México y Chile: una revisión de estudios. Revista Latinoamericana de Ciencias de la Comunicación, 14(26), 86-95.

Deuk Hyun, K. \& Kim, J. (2015). Differential and interactive influences on political participation by different types of news activities and political conversation through social media. Computers in Human Behavior, 45, 328-334. Doi: 10.1016/j.chb.2014.12.031.

Fernández-Poncela, A. (2015). Ayotzinapa, protestas, solidaridades y movimientos juveniles en México. Boletin Cientifico Sapiens Research, 5(2), 61-65.

Fukuyama, F. (1999). Social Capital and Civil Society. Washington: George Mason University.

Galindo, J. \& González, J. (2013). \#Yosoy132: La Primera Erupción Visible. México: Global Talent University Press.

Gil de Zúñiga, H., Veenstra, A., Vraga, E. \& Shah, D. (2010). Digital Democracy: Reimagining Pathways to Political Participation. Journal of Information Technology \& Politics, 7(1), 36-51. doi: 10.1080/19331680903316742. 
Heras, L. \& Díaz, O. (2017). Las redes sociales en las elecciones de 2015 en el Estado de México. Apuntes Electorales, 57, 71-108.

Kim, H. (2018). Effects of social capital on collective action for community development. Social Behavior and Personality, 46(6), 1011-1028

Kook Lee, J., Choi, J., Kim, Ch. y Kim, Y. (2014). Social Media, Network Heterogeneity, and Opinion Polarization. Journal of Communication, 64 ,702-722. Doi: 10.1111/jcom.12077.

Kushin, M. T. y Yamamoto, M. (2010). Did Social Media Really Matter? College Students' Use of Online Media and Political Decision Making in the 2008 Election. Mass Communication \& Society, 13(5), 608-630. doi:10.1080/15205436.2010.516863.

Lemus, R. (2015). La insubordinación del público: intelectuales y redes sociales en Mexico. Revista de Estudios Hispánicos, 49, 227242.

Mcevoy, C. (2016). The Role of Political Efficacy on Public Opinion in the European Union. JCMS, 54 (5), 1159-1174. doi: $10.1111 /$ jcms. 12357

Millaleo, S. (2011). La ciberpolítica de los movimientos sociales en Chile: algunas reflexiones y experiencias. Revista Anales, 2, 89104.

Mijares, F. R. (2006). Desafección política: principal causa del abstencionismo electoral en México. Apuntes Electorales, 5(23), 970 .

Min, K. (2006). Effects of Internet Use on College Students' Political Efficacy. CyberPsychology \& Behavior, 9(4), 415-422. doi:10.1089/cpb.2006.9.415.

Navia, Patricio \& Paz, Camilla (2017). Tuiteo, luego voto. El efecto del consumo de medios de comunicación y uso de redes sociales en la participación electoral en Chile en 2009 y 2013. Cuadernos.info, 40, 71-88. https://doi.org/10.7764/cdi.40.1049

Orellana, Cristian; Bivort, Bruno; Martínez, Soledad; Farías, Fernando; Cárcamo, Héctor; Blanco, Enrique \& Pérez, Gabriel (2015). Formación ciudadana y participación política en jóvenes de la Universidad del Bío-Bío, Chile. Civilizar, 15(28), 119-134.

Oser, J., Hooghe, M. y Marien, S. (2013). Is Online Participation Distinct from Offline Participation? A Latent Class Analysis of 
Participation Types and Their Stratification. Political Research

Quarterly, 66 (1), 91-101. doi: 10.1177/1065912912436695.

Peña, R. (2015). Cultura de la legalidad en contextos de violencia. El fenómeno de Hagámoslo Bien en Monterrey. Revista Mexicana de Opinión Pública, 20, 107-127.

Pishghadam, R., Nohani, M. y Zabihi, R. (2011). The Construct Validation of a Questionnaire of Social and Cultural Capital. English Language Teaching, 4 (4), 195-203. doi:

10.5539/elt.v4n4p195.

Putman, R.D. (1995). Making Democracy work: civic traditions in modern Italy. Princeton: Princeton University Press.

Quiñónez, L. (2014). Medios y elecciones 2012: viejos y nuevos desafíos para la comunicación política en México. Nóesis: Revista de Ciencias Sociales y Humanidades, 23(45), 24-48.

Ramos, I., Contreras, C., y García, A. (2014). México: Un eje central en el desarrollo de las redes hispanas. REDES-Revista hispana para el análisis de redes sociales, 25 (1), 49-67.

Red, M. (2013). Rocking the Vote in Mexico's 2012 Presidential Election: Mexico's Popular Music Scene's Use of Social Media in a Post-Arab Spring Context. International Journal of Communication, 7, 1205-1219.

Reichert, F. (2016). How Internal Political Efficacy Translates Political Knowledge Into Political Participation. Europe's Journal of Psychology, 12 (2), 221-241. doi:10.5964/ejop.v12i2.1095

Riaz, J. \& Javaid, U. (2017). Political Socialization in Pakistan: A Study of Political Efficacy of the Students of Madrassa. $A$ Research Journal of South Asian Studies, 32 (2), 363-368.

Roldan, M., Sustanonpaiboon, J. \& Burkhard, R., (2017). Professional and Personal Social Network and Enhancement of Social Capital in Young Adults. Professional and Personal Social Networking, 26(3), 46-80.

Rojas, M. D. \& Marin, S. P. (2006). Aproximaciones a la medición de la confianza. Dyna, 73(150), 119-130.

Serek, J., Machackova, H. \& Macek, P. (2017). The Chicken or Egg Question of Adolescents' Political Involvement. Zeitschrift für Psychologie, 225 (4), 347-356.

Sola, S. \& Hernández, V. (2017). Voter Turnout and New Forms of Political Participation of Young People: A Comparative 
Analysis between Chile and Spain. Revista Latina de Comunicación Social, 72, 629-648.

Solís, I. (2016). El caciquismo en México: la otra cara de la democracia mexicana. El caso del caciquismo urbano en el Estado de México. Estudios Políticos, 7, 167-192.

Subsecretaría de Telecomunicaciones (2017). Penetración de Internet marca alza del 25\% y llega a los 16,7 millones de accesos. Recuperado el 31 de marzo de 2019 de: https://www.subtel.gob.cl/penetracion-de-internet-marca-alzadel-25-y-llega-a-los-167-millones-de-accesos /

Tin, S., y Wan, S. (2018). Influence of Media on University Students' Efficacy in Participating in Political Conversations. Global Business and Management Research: An International Journal, 10 (2), 198-206.

Tully, M., y Vraga, E. (2018). A Mixed Methods Approach to Examining the Relationship Between News Media Literacy and Political Efficacy. International Journal of Communication, 12, 766787.

Vera, S. (2011). El resplandor de las mayorías y la dilatación de un doble conflicto: el movimiento estudiantil en Chile el 2011. Anuari del Conflicte Social, 1, 286-309.

Vesnic-Alujevic, L. (2012). Political participation and web 2.0 in Europe: A case study of Facebook. Public Relations Review, 38(3),466-470. doi: 10.1016/j.pubrev.2012.01.010.

Wolak, J. (2018). Feelings of Political Efficacy in the Fifty States. Polit Behav, 40, 763-784. Doi: https://doi.org/10.1007/s11109-0179421-9

Zeng, R., Chen, Y, y Li, H. (2018). Participation in collective action in china: unfair experience, interests involved, and political efficacy. Social Behavior and Personality: an international journal, 46 (9), 1561-1572. doi: https://doi.org/10.2224/sbp.7117 



\title{
Os jovens brasileiros e a movimentação entre tribos digitais
}

\author{
Tiago Luís Rigo \\ Pontifícia Universidade Católica do Rio Grande do Sul (Brasil) \\ Tiago.luis.rigo@gmail.com \\ Mágda Rodrigues da Cunha \\ Pontifícia Universidade Católica do Rio Grande do Sul (Brasil) \\ mrcunha@pucrs.br
}

PARA CITAR: Rigo, T. L. \& Rodrigues da Cunha, M. (2019). “O jovem e a movimentação entre as tribos digitais". En Barredo Ibáñez, D.; Cunha, M. R. \& Hidalgo Toledo, J. (Eds.) (2019). Jóvenes, participación y medios de comunicación digitales en América Latina <pp. 85-101>. La Laguna, España: Cuadernos Artesanos de Comunicación. DOI: 10.4185/cac156

\section{Resumo}

O contexto de ubiquidade, no qual o jovem está presente, sua relação com a mídia, fazendo parte dela e constituindo grupos a partir dos recursos tecnológicos, indica um ecossistema de múltiplos e intensos acessos às redes sociais, mas instável, na mesma medida. Neste texto, buscamos observar o cenário em que estas conexões se desenrolam e identificar as motivações de uma migração do Facebook para outras plataformas. Inicialmente, recorremos a estudos quantitativos, realizados por diferentes institutos e, em um segundo momento, realizamos investigação qualitativa, na busca de explicar as transformações. As teorias desenvolvidas por Michel Maffesoli contribuem para essa análise, especialmente os conceitos presentes em sua obra $O$ tempo das tribos, assim como entrevistas recentes, em que o sociolólogo revisita seus estudos mais antigos. 


\section{Palavras-Chave}

Comunicação, Jovem, Tecnologia, Tribos, Redes sociais.

\section{Introdução}

COSTUMAMOS atribuir ao jovem um perfil questionador, inquieto e transgressor, sendo a juventude percebida como a etapa de transição e formação para a vida adulta. Definir juventude, hoje, passa por localizar esse sujeito dentro de uma faixa etária específica, considerando o contexto. Para a Organização das Nações Unidas (ONU), juventude corresponde à fase entre os 15 e os 24 anos. Esse recorte contempla um intervalo de nove anos, categorizando da mesma forma o jovem que nasceu em 1994 e o nascido em 2003.

Essa amplitude precisa ser considerada, especialmente, na linha do imaginário tecnológico, por entender que a tecnologia se fez disponível de formas diferentes em cada período. As transformações decorrentes disso causam impactos, mudam a forma de se relacionar, de comunicar, de consumir e de produzir conteúdo por esses sujeitos.

O pesquisador americano Clay Shirky aborda aspectos geracionais e a importância de identificarmos o contexto nesse tipo de análise. Em Cultura da participação (2010), Shirky pontua que as gerações se diferenciam, contudo, menos porque as pessoas se diferenciam, e mais porque as oportunidades são diferentes:

Teorias de diferenças de gerações fazem sentido quando são formuladas como teorias de diferença ambiental, e não de diferença psicológica. As pessoas, e em especial os jovens, responderão a incentivos porque têm muito a ganhar e pouco a perder com a experimentação (Shirky, 2010, p. 112).

Outro autor que contribui para esse entendimento é Marc Deuze, ao investigar, entre outros temas, as relações entre o indivíduo e a sociedade. Nesta conexão Deuze conceitua que a vida é vivida na mídia e não com a mídia, sugerindo, que as pessoas não vivem essas oportunidades da mesma forma. Em Media life (2011), indica que a 
mídia é a base e o contexto de expressões e experiências de vida, que permeia todos os aspectos do cotidiano e tende a gerar um desaparecimento da mídia da consciência coletiva. Sendo assim, compreende a mídia como ubíqua, estando em todos os lugares, permitindo que todos os sujeitos possam ser mídia. É justamente nesse ecossistema que localizamos o jovem ubiquo, que cresce em um ambiente de transformação, mas caracteriza-se de acordo com seu contexto e disponibilidade de tecnologia (Shirky, 2010), sendo um sujeito que vive a mídia (Deuze, 2011). A correlação e os impactos destes elementos na vida do jovem pode ser encontrada nos estudos de Danah Boyd, especialmente na obra, It's complicated: The social lives of networked teens (2014), um estudo que ouviu 166 jovens americanos entre 2005 e 2012.

Segundo Boyd (2014), ao contrário da primeira geração a tomar contato com as redes sociais, nos anos 1990, cuja intenção, em boa parte, era fugir do mundo real e do contexto em que viviam, os jovens participantes da pesquisa demonstram usar as redes sociais para entrar em contato com pessoas de sua comunidade, pessoas conhecidas, numa continuidade do que vivem na vida off-line. Boyd (2014) constata que "as interações mediadas dos adolescentes complementam ou suplantam, por vezes, os seus encontros face a face” (p.21). Mais do que isso, demonstram o quanto os adolescentes estão ali por motivações sociais, e não simplesmente pela tecnologia em si. A autora desmistifica ainda, o conceito de jovens viciados em telefones ou computadores pois, segundo ela, os jovens são viciados em seus grupos de amizade, mais do que na tecnologia em si.

"Os pais não sabem a importância que a mobilidade assumiu na vida dos jovens. Eles pensam apenas sobre a função comunicação e não sobre o sentido social". A afirmação de uma jovem, conforme apresenta Stald (2008), no texto Mobile Identity: Youth, Identity, and Mobile Communication Media, evidencia a lacuna na compreensão dos chamados imigrantes digitais em relação à apropriação das tecnologias de comunicação. Para a jovem, um telefone celular é um dispositivo, por intermédio do qual ocorre a comunicação e através do qual os indivíduos mantém contato social. 


\section{As tribos e seu tempo}

Para identificar as novas massas constituídas por pessoas que se relacionam a partir de seus interesses, e não mais por uma estrutura pré-estabelecida, Michel Maffesoli fala de uma volta às tribos. Tais comunidades, tratadas pelo autor como tribos, são observadas em diferentes segmentos da sociedade. Neste artigo, destacamos o jovem.

A expressão tribalismo, do modo como é utilizada por Maffesoli, significa o processo de identificação entre os sujeitos "que possibilita o devotamento graças ao qual se reforça aquilo que é comum a todos" (2010, p. 123). O sociólogo parte da perspectiva de que existe uma multiplicação de aldeias nos dias atuais, como resposta a um espírito do tempo no qual o território tornou-se um espaço para diversas manifestações.

Compreendemos a internet, no ambiente das redes sociais, como uma analogia aos territórios identificados por Maffesoli. A partir das comunidades e grupos de interesse, são criadas microtribos identificadas por características comuns, encontrando nesses espaços formas de expressar suas identidades. Nesta aproximação, entendemos, neste artigo, as redes sociais, tais como Facebook e Instagram, como tribos pós-modernas.

Em entrevista reproduzida no site Fronteiras do Pensamento, Maffesoli (2015) caracteriza o momento atual como tempo das tribos, relacionando o desenvolvimento tecnológico com uma maneira diferente de viver os laços sociais. Segundo o autor, as tribos pós-modernas surgem devido à expansão da internet e da tecnologia:

Assim como o desencantamento do mundo conduziu à solidão, o Facebook, o Second Life etc., para o melhor e para o pior, recuperaram o ideal comunitário. [...] Isto é, chegamos a uma sociedade que enfatiza a relação com o outro. E isso nos obriga a mudar nossa maneira de analisar a sociedade. Não é mais o caso de ser otimista ou de ser pessimista, mas de observar o mundo tal qual ele é (Maffesoli, 2015). 
O jovem contemporâneo, objeto de estudo deste artigo, em sua relação com outro observada por Maffesoli e Boyd, encontra nas redes sociais seu espaço de expressão e identidade. Em entrevista ao Jornal Estado de São Paulo (2014), Maffesoli cita Hegel, quando este diz que o jornal é a oração matinal do homem moderno e para Maffesoli, as redes sociais serão a oração do homem pós-moderno.

\section{Presença nas redes sociais}

Traçado este panorama, sobre como identificamos e contextualizamos esse sujeito jovem, buscamos compreender seus comportamentos na internet, sua participação em redes sociais e, à luz dos estudos de Maffesoli, relacionamos seus movimentos de transição entre as diferentes plataformas digitais. $O$ objeto é analisado de forma quantitativa, a partir de estudos já realizados, e qualitativa, tendo em vista as características de uma pesquisa na internet:

A internet é um universo de investigação particularmente difícil de recortar, em função de sua escala (seus componentes contamse aos milhões e bilhões), heterogeneidade (grande variação entre as unidades e entre os contextos) e dinamismo (todos os elementos são permanentemente passíveis de alteração e a configuração do conjunto se modifica a cada momento) (Fragoso, Recuero e Amaral, 2011, p. 55).

A pesquisa explicativa aqui realizada é definida por conta da complexidade do objeto. Para somar uma perspectiva quantitativa a este estudo, recorremos a institutos de pesquisas que publicaram relatórios em 2018. O primeiro deles, o Pew Research Center, buscou identificar o comportamento de jovens entre 13 e 17 anos, relativo aos usos de tecnologias e redes sociais. A pesquisa Teens, Social Media \& Technology (2018), aponta que o YouTube, o Instagram e o Snapchat são as plataformas mais populares entre jovens desta faixa etária.

Essa mesma pesquisa foi realizada em 2015, tornando possível comparações entre os dados obtidos em períodos diferentes. De acordo com o Pew Reserch Center, 85\% dos jovens dizem usar o YouTube (plataforma não mapeada no estudo de 2015); o Instagram aparece com 
$72 \%$ (52\% diziam usar em 2015); o Snapchat com 69\% (41\% diziam utilizar em 2015) e o Twitter com 32\% (31\% diziam utilizar em 2015).

A rede social líder da preferência entre jovens americanos, na pesquisa realizada em 2015, era o Facebook, com 71\%. Os dados de 2018 indicam uma redução de 20 pontos percentuais, alcançando $51 \%$ e, com esse indicador, fica atrás do YouTube, do Instagram e do Snapchat. Essa foi a maior variação apontada pelo relatório, que aponta uma perda de popularidade desta rede social em relação a este público. Para a realização da pesquisa, o instituto entrevistou 1058 pais americanos com filhos entre 13 e 17 anos, além de 743 jovens desta faixa etária, entre 7 de março e 10 de abril de 2018.

Contribui com essa análise do público americano a pesquisa Social Media, Social Life: Teens Reveal Their Experiences, realizada pela Common Sense, organização sem fins lucrativos, que promove tecnologia segura para crianças, que ouviu 1141 jovens entre 13 e 17 anos nos Estados Unidos. Divulgada pela BBC News Brasil (2018), o relatório indica que, em 2012, quando a pesquisa foi realizada pela primeira vez, o Facebook era apontado como a principal rede social por $68 \%$ dos jovens, enquanto em 2018, apenas 15\% respondem da mesma forma.

Sobre a realidade brasileira, este artigo relaciona dados do consumo geral de internet e redes sociais no país, tendo como base o estudo Digital in 2018: world's internet users pass the 4 billion mark, realizado pela agência We Are Social. De acordo com o relatório, o número de brasileiros com acesso à internet é de 139,1 milhões. Estes, dedicam, em média, 9 h14min em diferentes dispositivos. Em redes sociais, o tempo de consumo diário do brasileiro é de 3 h39min. Nesse cenário de disponibilidade de acessos, o YouTube é a plataforma com maior número de usuários (60\%), sendo o Facebook o segundo (59\%). A pesquisa revela ainda os aplicativos mais baixados pelos usuários brasileiros. Dos cinco mais adquiridos, quatro são de interação social: Whats App, Facebook, Facebook Messenger e Instagram.

Os três relatórios quantitativos apresentados, We Are Social (2018), Common Sense (2018) e Pew Research Center (2018), indicam a crescente utilização de redes sociais e, ao mesmo tempo, uma redução da 
preferência pelo Facebook, aparecendo na liderança o YouTube como plataforma mais acessada.

\section{Em busca de novas tribos}

A partir da constatação de um movimento dos jovens entre redes sociais, buscamos encontrar elementos qualitativos para a compreensão deste fenômeno de saída do Facebook. Fragoso, Recuero e Amaral indicam as características deste tipo de pesquisa, que encontra na Internet seu campo de análise:

A pesquisa qualitativa visa uma compreensão aprofundada e holística dos fenômenos em estudo e, para tanto, os contextualiza e reconhece seu caráter dinâmico, notadamente na pesquisa social. Nesse contexto, o número de componentes da amostra é menos importante que sua relevância para o problema de pesquisa, de modo que os elementos da amostra passam a ser selecionados deliberadamente, conforme apresentem as características necessárias para a observação, percepção e análise das motivações centrais da pesquisa (Fragoso, Recuero e Amaral, 2011, p. 67).

Para este artigo, utilizamos, como categoria de análise, uma amostra intencional, categoria elencada por Fragoso, Recuero e Amaral (2011), que descreve uma amostra qualitativa "cujos elementos são selecionados conforme critérios que derivam do problema de pesquisa, das características do universo observado e das condições e métodos de observação e análise" (p.78). Sendo assim, utilizamos o YouTube como fonte de pesquisa e os vídeos, localizados nesta plataforma, como elementos desta análise.

A escolha do YouTube é justificada pelas pesquisas quantitativas que indicam a preferência do público jovem por essa plataforma. Para coleta de dados, realizamos um levantamento digitando no campo de busca do site a expressão que decorre do nosso problema de pesquisa: Por que en saí do Facebook? A pergunta, em primeira pessoa, foi intencionalmente construída desta forma pois, como resultado, 
buscamos vídeos testemunhais, protagonizados por jovens que descrevem motivos que os levaram a deixar determinada rede social.

A configuração de busca, da forma descrita acima, foi realizada em 18 de novembro de 2018 e resultou em 52 itens. Excluímos da amostra vídeos com conteúdo tutorial, com a finalidade de explicar como excluir perfis do Facebook e, ainda, usuários que indicaram ter saído definitivamente de todas as redes sociais. Vale ressaltar que a pesquisa qualitativa, aqui apresentada, de amostragem intencional, não tem como finalidade oferecer uma generalização a partir de casos particulares, o que não seria possível. Objetivamos apresentar alguns elementos que contribuem para a reflexão proposta pelo artigo, trazendo aspectos da obra de Maffesoli como elemento teórico agregador para a análise.

Reunimos sete vídeos na amostra final que, juntos, contabilizam 46 minutos de conteúdo que responde à pergunta: Por que eu saí do Facebook? O questionamento inserido no campo de buscas da plataforma de compartilhamento de vídeos resultou em diferentes títulos. Os selecionados para essa análise são os seguintes: Porque eu não tenho mais Facebook (Ana Karine, 2018); Porque en odeio o Facebook (Blog Quase Gêmeas, 2016); Porque eu parei de usar facebook (Bruno JVP, 2015); Diário em vídeo \#1: Por que exclui men face (Erica Castelo Branco, 2018); Porque exclui men facebook (Jess Maria, 2017); Porque sai do facebook? (Marusa Bárbara, 2017); Eu não tenho mais paciência! (Monika Hegler, 2017) ${ }^{10}$.

Como ponto de partida, decupamos o conteúdo dos vídeos selecionados e categorizamos temas recorrentes que motivaram a saída dos jovens do Facebook. A justificativa que aparece com maior recorrência está relacionada ao conteúdo encontrado na rede social. Bruno JVP (2015) relata que sua timeline é "uma coisa insuportável", referindo-se às discussões, principalmente sobre política, entre pessoas que ele conhece. "Ninguém usa Facebook para desestressar, ficam mais estressados”. As percepções de Jess Maria (2017) também fazem referência ao mesmo tópico. "O Facebook só te traz notícia ruim, fofoca desnecessária de pessoas que você conhece. Virou um Orkut. O

${ }^{10}$ Tanto os títulos dos vídeos, quanto suas transcrições levaram em consideração a grafia original utilizada pelos criadores dos conteúdos. 
excesso de conteúdo sobre política e as fakenews também aparecem como motivos:

Tá muito chato. Não pode mais postar nada. Posta uma brincadeira e polemiza. E tem mais, as vezes faz um post e meu deus como a galera comenta absurdos. Perde o controle, não é mais o teu post, é o da galera. As linguagens são tão agressivas, as pessoas te agridem na hora de comentar. O mais engraçado é que essas pessoas que estão comentando, são teus amigos. Você espera gentileza, outras ideias que venham para somar, dos amigos. Não tá dando não! (Monika Hegler, 2017).

Os elementos ilustrados pelos jovens relacionam-se com o pensamento de Maffesoli, quando o autor indica aspectos relacionados com o emocional e ao afeto como fatores de pertencimento às tribos pósmodernas. $\mathrm{Na}$ inexistência desses elementos, uma busca por novos espaços de expressão, ou outras redes sociais, neste caso, justifica-se:

À semelhança das tribos tradicionais, as tribos pós-modernas se encontram ao redor de seus totens e se comunicam através deles. Enquanto a razão privilegiava o que é íntimo, o retorno da imagem nos leva a compartilhar o emocional. Não sei se é o caso de pensar em um avanço ou em uma regressão. Hoje, ao contrário, essa mesma técnica promove o retorno dos afetos (Maffesoli, 2015).

Ainda nesta entrevista, Maffesoli atribui à internet e, também, às redes sociais, a possibilidade de acessarmos "não mais um outro mundo, mas sim um mundo outro":

[...] |Existe hoje, em particular entre as jovens gerações, uma inegável vitalidade, que se exprime em novas formas de solidariedade e de generosidade. A web favorece antigas formas de hospitalidade, que foram a marca das sociedades prémodernas. Desse ponto de vista, sim, sou um otimista (Maffesoli, 2015). 
Em oposição a estes elementos refletidos por Maffesoli, tais como solidariedade e generosidade, a jovem Ana Karine (2018) relata falta de identificação com o conteúdo e a faixa etária dos usuários presentes no Facebook. Em seu vídeo, ela aponta, entre outras justificativas, a presença de pessoas "idosas que postam mensagens coloridas" e mensagens recorrentes de "bom dia" ou "boa noite". Tais características são decorrentes dos recursos disponibilizados pelo Facebook para customização de imagens e textos, que ampliam as possibilidades de representação.

Outra justificativa identificada nos vídeos da amostra tem relação com a dependência gerada pela rede social e o tempo dedicado para ela. "Eu estava mexendo tanto no Facebook que eu não estava conseguindo fazer as minhas coisas. Eu queria ver o tempo todo o que tinha no Facebook, ficava atualizando ele o tempo inteiro", relata Jess Maria (2017). A exposição, também é considerada demasiada por outra jovem:

O Facebook não é mais para mim. O principal motivo foi a exposição da minha vida. Facebook hoje não é tanto para interação, virou uma vitrine da sua vida, posta o que quer mostrar pra todo mundo. Será que eu preciso da aprovação das pessoas? (Marusa Barbara, 2017)

As protagonistas do canal Blog Quase Gêmeas são irmãs e, juntas, descrevem os motivos que as levaram a abandonar o Facebook. Os esforços dedicados à plataforma versus a visibilidade alcançada é considerado, por elas, o principal motivo.

A gente odeia o Facebook. Temos mais de 10 mil seguidores, mas o problema é que eu faço uma postagem e ele mostra só para 50 pessoas. Que raiva! É uma coisa desesperadora. Eu tenho certeza que era para ter um monte de likes, mas o Facebook não mostra. [...] é muito triste, você se maquia, tira foto, pensa o que vai escrever e Facebook mostra pra poucas pessoas. Isso é um absurdo! (Blog Quase Gêmeas, 2016).

Dentre os vídeos selecionados na amostra, dois trazem em seu conteúdo relatos de ódio pelo Facebook e narram estar mais felizes sem 
utilizar a rede social. "A rede social não é ruim, o que estraga são as pessoas que estão dentro dela. Eu tenho outras redes sociais, Tumblr, Snap, Instagram. Estou até melhor sem”, conta Jess Maria (2017).

Tal motivação, para a mudança de rede social, em busca de um bemestar e visibilidade, encontra em Maffesoli uma reflexão. $\mathrm{O}$ autor entende que as tribos são unidas por um laço afetivo, emocional, mais que por contratos sociais. Quando um destes elementos se perde, o sujeito busca outra tribo:

A metáfora da tribo, por sua vez, permite dar conta do processo de desindividualização, da saturação, da função que lhe é inerente, e da valorização do papel que cada pessoa (persona) é chamada a representar dentro dela. Claro está que, como as massas em permanente agitação, as tribos, que nelas cristalizam, também são pouco estáveis. As pessoas que compõem essas tribos podem evoluir de uma para a outra (Maffesoli, 2010, p.31).

Complementando esse conceito, o autor pontua que a constituição em rede, dos microgrupos contemporâneos, é "a expressão mais acabada da criatividade das massas" (Maffesoli, 2010, p.165). O autor remete à antiga noção de comunidade e destaca o aspecto orgânico, de agregação social.

O movimento de saída dos jovens do Facebook para outras redes sociais acompanha uma característica deste público por busca de reconhecimento e espaços em que possa divulgar seu sucesso e felicidade:

De fato, as mídias sociais (Facebook, Instagram, Twitter, etc.) tendem a dar uma figuração feliz de nós mesmos. Certamente não estamos sempre felizes. Mas há aí um movimento de pudor: nós tendemos a dar à tribo, ou às diversas tribos às quais pertencemos, imagens reconfortantes de nós mesmos (MAFFESOLI, M. Jornal Estado de São Paulo, 2014).

O sociólogo identifica essa possibilidade de o indivíduo fazer parte de diferentes tribos, ao mesmo tempo, como parte de uma identidade 
social multifacetada e construída a partir de diferentes ordens de interesse:

$\mathrm{Na}$ modernidade, o que caracterizava o indivíduo era a sua função social, fosse na sociedade como um todo, fosse nos partidos, associações ou grupos estáveis. Na pós-modernidade, "a persona representa papéis, tanto no interior de sua atividade profissional como no seio das diversas tribos das quais participa (Maffesoli, 2010, p.98).

Partimos do pressuposto de que as relações sociais produzidas nas redes sociais acentuam o sentimento de estar-junto, identificado por Maffesoli. A ligação pessoal aos demais integrantes da tribo, geralmente está associada com o compartilhamento de um gosto, seja ele sexual, musical, religioso, esportivo, etc:

Nessa perspectiva, as mídias sociais são ao mesmo tempo um meio e uma mensagem, que confortam a vida em sociedade. Se a modernidade se firmou a partir de um princípio individualista, a tecnologia pós-moderna abriga um relacionismo galopante - uma relação, como frisei, entre nós e os outros (Maffesoli, 2014).

Trinta anos depois do lançamento de O tempo das tribos, Maffesoli confirma sua hipótese: "Parece-me que o relacionamento, o laço social, é elemento essencial da pós-modernidade. $\mathrm{O}$ desenvolvimento tecnológico, como evidenciado pelas redes sociais, tende a reforçar a importância de viver juntos, do vínculo" (Jornal Estado de São Paulo, 2014).

As pesquisas de Danah Boyd (2014) também indicam as motivações sociais dos jovens para o uso de tecnologias, especialmente as redes sociais. Segundo ela, o afeto entre os jovens aumenta e sua atuação em redes amplia seus contatos e relacionamentos, sem distinção de vida online ou off-line. Jenkins, Ito e Boyd (2016) indicam que a juventude é tida como tecnologicamente sofisticada, isso num subproduto de seu nascimento. Pouco se considera a diversidade pela qual estes nativos digitais experienciam a tecnologia. Esta linguagem, paralela à noção mais ampla das gerações, obscurece as nuances da participação dos 
jovens. Os autores relembram que eles não são os únicos a usar as novas tecnologias digitais. Os aparelhos móveis e as redes sociais proporcionaram aos adolescentes conectarem-se uns aos outros em formatos sem precedentes. As diferenças entre como várias populações de jovens usam tecnologia são tão importantes quanto compreender as diferenças entre jovens e mais velhos.

\section{Por que eu saí do Facebook?}

Acompanhar e investigar as movimentações do público em um contexto complexo, determina que lancemos mão de estratégias combinadas. Neste texto, o objetivo foi descrever e explicar as transformações na conexão dos jovens com as redes sociais, dando centralidade à migração do Facebook para outros ambientes digitais. Autores aqui elencados evidenciam o cenário em que este jovem está presente, o modo e os motivos pelos quais estabelece suas relações sociais online. Pesquisas quantitativas comprovam o movimento aqui descrito. Numa perspectiva qualitativa, tentamos compreender e explicar os porquês. Além dos autores que descrevem o contexto, o pensamento de Maffesoli, ao refletir sobre as tribos, tema central em sua obra, foi a base para a análise aqui proposta.

As narrações apresentadas pelos jovens, nos vídeos do YouTube, vão ao encontro da descrição de tribos pós-modernas desenvolvida por Maffesoli, definidas como comunidades empáticas, organizadas em torno do compartilhamento de gostos e cujos vínculos perduram enquanto for mantido o interesse pela atividade. Compreendemos as construções e o movimento de transição dessas redes como maneira de pensar e de se relacionar desse público. Entre as características do jovem está a autonomia e o protagonismo: eles procuram suas redes, escolhem, apropriam-se e definem padrões e regras.

Destacamos que, ao utilizarmos o termo jovem caracterizamos sujeitos que possuem entre 15 e 24 anos, numa perspectiva de juventude como período de transição e experimentação. Ao mesmo tempo, o conjunto de características que identificam o jovem são projetadas por outros grupos, numa espécie de juventude prolongada. "O falar jovem, o vestir-se jovem, os cuidados com o corpo, as histerias sociais são, 
amplamente, partilhadas. Cada um, quaisquer que sejam sua idade, sua classe, seu status, é, mais ou menos, contaminado pela figura da criança eterna" (Maffesoli, 2010, p. 9).

Conforme indicamos, a disponibilidade de tecnologia trouxe impactos e possibilidades, mas sem caracterizar uma generalização. No entendimento de Deuze, vive-se a mídia, mas Shirky sinaliza que as oportunidades diferentes de acesso indicam, mesmo ao jovem que busca experimentação, uma necessidade de aprofundar a análise contextual e não generalista.

Sendo assim, buscamos localizar e compreender o movimento de mudança de redes sociais, sob o ponto de vista do próprio jovem, lançando referenciais para seus próprios espaços de interação, como o Facebook e o YouTube. Os recortes de pesquisa e falas descritas neste artigo não objetivam conclusões que possam ser atribuídas a todos os jovens, mas sim, em forma de exercício, foi possível relacionar comportamentos e características deste público no contexto das suas tribos pós-modernas.

Categoria central, o conceito de tribo, em Maffesoli, define a relevância constante dos laços sociais. Este é o principal objetivo e ponto comum na análise de todas as investigações e pensamentos. Incentivadas, no entanto, pela própria expansão tecnológica, multiplicam-se as tribos e consequentemente as alternativas para filiar-se a comunidades devotas a algo comum. E este interesse pode variar de maneira dinâmica e com certa velocidade, como foi aqui identificado, conectando os sujeitos a uma ou mais microtribos. Estes ambientes ou territórios tornam-se espaço para manifestações e expressão de identidades.

Paradoxalmente, conforme os resultados da pesquisa, a partir da pergunta Por que eu saí do Facebook?, a mesma expansão da rede leva à saturação. A principal queixa dos jovens diz respeito ao excesso de tempo gasto em postagens, conteúdos polêmicos e especialmente voltados à política, pouca visibilidade para a dedicação e a faixa etária dos novos frequentadores deste ambiente. Já há algum tempo, dados apontam que os jovens começaram a deixar o Facebook no momento em que seus pais e avós passaram a integrar esta rede social. E, se como 
define Maffesoli, na metáfora da tribo, há a valorização do papel que cada pessoa (persona) é chamada a representar dentro dela, para um jovem, com as características desta fase da vida, também é mais complexo gastar tempo e não obter a visibilidade procurada. Torna-se difícil expressar sua identidade no mesmo ambiente em que estão seus pais e avós, abordando pensamentos políticos, usando recursos gráficos do Facebook. Tudo isto indica que, sim, estas comunidades são instáveis e consequentemente migram para outros ambientes compatíveis com seus objetivos.

\section{Referências}

Amaral, A; Fragoso, S.; Recuero, R. (2011). Métodos de pesquisa para internet. Porto Alegre: Sulina.

Boyd, D. (2014). It's Complicated: The social lives of networked teens. Londres: Yale University Press.

Deuze, M. (2011). Media life. Media, Culture \& Society. EUA: Polity. Jenkins, H.; Ito, M.; Boyd, D. (2016). Participatory culture in a networked era. A conversation on Youth, learning, commerce, and politics. Cambridge: Polity Press.

Maffesoli, M. (2010) O tempo das tribos: O declínio do individualismo nas sociedades de massa. Rio de Janeiro: Forense Universitária.

Shirky, C. (2010) A cultura da participação, criatividade e generosidade no mundo conectado. Rio de Janeiro: Zahar.

Stald, G. (2008) Mobile Identity: youth, identity, and mobile communication media. En Buckingham, David. (Org.) Youth, identity, and digital media. Cambridge: The MIT Press.

\section{Conteúdos na Internet}

Pew Research Center. "Teens, social media \& technology”. 2018.

Disponível em:

$<$ http://www.pewinternet.org/2018/05/31/teens-socialmedia-technology-2018>. Acesso em: 18/11/2018.

BBC News Brasil. "Só uso Facebook para falar com meus avós: pesquisa mostra o que mudou na relação entre jovens e redes sociais nos EUA". 2018. Disponível em: 
<https://www.bbc.com/portuguese/salasocial-45470711>. Acesso em: 18/11/2018.

We Are Social. "Digital in 2018: World's internet users pass the 4 billion mark". 2018. Disponível em $<$ https://wearesocial.com/blog/2018/01/global-digital-report2018>. Acesso em 18/11/2018.

Fronteiras do Pensamento. Entrevista com Michel Maffesoli. 2015.

Disponível em

$<$ https://www.fronteiras.com/entrevistas/michel-maffesoli-eo-homo-eroticus-pos-moderno-voltamos-ao-que-o-

racionalismo-moderno-eliminou $>$. Acesso em 18/11/2018.

Jornal Estado de Sâo Paulo. Entrevista com Michel Maffesoli. 2014.

Disponível em

$<$ https://www.estadao.com.br/noticias/geral,retrato-de-umajuventude,1167792>. Acesso em 18/11/2018.

\section{Vídeos do YOUTUBE}

Ana Karina. "Porque eu não tenho mais Facebook". (6min33). 2018. Disponível em:

$<$ https://www.youtube.com/watch?v $=$ Vl2nKOuSHQQ\&t=36 s>. Acesso em 18/11/2018.

Blog Quase Gêmeas. "Porque eu odeio o Facebook". (5min55s). 2016. Disponível em:

<https://www.youtube.com/watch?v=RmQ17ObmhUI $>$. Acesso em: 18/11/2018.

Bruno JVP. "Porque eu parei de usar facebook". 2015. (6m41s).

Disponível em:

$<$ https: / /www.youtube.com/watch?v $=$ dhf2pgl9Bxw\&t=130s $>$ . Acesso em: 18/11/2018.

Erica Castelo Branco. "Diário em vídeo \#1: Por que exclui meu face”. (4min45s). 2018. Disponível em:

<https://www.youtube.com/watch?v=GGmpfMkALW8>. Acesso em 18/11/2018.

Jess Maria. "Porque exclui meu facebook". 2017. (3min15s).

Disponível em:

$<$ https: / $/$ www.youtube.com/watch?v $=$ Q8WffdjpYYI\&t $=67 \mathrm{~s}>$ . Acesso em: 18/11/2018. 
Marusa Bárbara. "Porque saí do facebook?” (13m48s). 2017.

Disponível em:

$<$ https://www.youtube.com/watch?v=V3F9pjqiUt0> Acesso em: 18/11/2018.

Monika Hegler. "Eu não tenho mais paciência!" (4min51s). 2017.

Disponível em: <https://www.youtube.com/watch?v=LF1xc6$5 g \mathrm{Og}>$. Acesso em 18/11/2018. 



\title{
Chairos contra Derechairos: El trolling y otras prácticas incendiarias de la comunicación en línea en un grupo temático sobre Historia, en Facebook
}

\author{
Enrique Iturralde Chaparro \\ Universidad Nacional Autónoma de México (México) \\ e iturralde@,comunidad.unam.mx
}

\begin{abstract}
PARA CITAR: Iturralde, E. (2019). “Chairos contra Derechairos: El trolling y otras prácticas incendiarias de la comunicación en línea en un grupo temático sobre Historia, en Facebook”. En Barredo Ibáñez, D.; Cunha, M. R. \& Hidalgo Toledo, J. (Eds.) (2019). Jóvenes, participación y medios de comunicación digitales en América Latina <pp. 103-132>. La Laguna, España: Cuadernos Artesanos de Comunicación. DOI: 10.4185/cac156
\end{abstract}

\section{Resumen}

Este trabajo investiga prácticas incendiarias de Internet, como el trolling, y construcciones de identidad en línea en usuarios mexicanos de un grupo de Facebook denominado Historia. A través de un estudio etnográfico de medios sociales, que incluye la elaboración de redes semánticas de las 10 publicaciones con más peso durante el periodo de un mes, se encontró que algunos integrantes de dicha comunidad interactúan a partir de contenidos afectivos y conductas cáusticas impulsadas por una doble agencia intrínseca a aparatos socio-tecnoculturales como Facebook, dentro de una sociedad red (Latour, 2007). También se observaron configuraciones de bandos identitarios a partir de reducciones dicotómicas de la realidad sobre los asuntos públicos de México, lo que podría apuntar a la construcción de democracias agonísticas basadas en el conflicto (Mouffe, 2000), pero que igualmente potencia el aumento de la polarización social, y las cámaras de eco, en 
un país cuyo proyecto de nación, lejos de ser un proceso lineal consolidado, se encuentra en constante disputa.

\section{Palabras clave}

Teoría del Actor Red, Esfera pública, Democracias agonísticas, Redes sociales digitales, Trolling, Hating, Facebook.

\section{Introducción}

$\mathrm{L}$

A COMUNICACIÓN en línea posibilita la deliberación entre las personas, pero también propaga prácticas que se consideran ajenas a los principios de racionalidad que, según académicos como Habermas (1987), fundamentan a las democracias liberales. El robo de datos, el espionaje, la manipulación informativa, las falsas noticias, las cámaras de eco en las que solo resuena lo que queremos ver y las manifestaciones de odio se han convertido en una constante que ha sido alertada por diversos investigadores desde hace tiempo (Jarret, 2008; Jamieson y Capella, 2008; Shepherd, Harvey, Jordan, Srauy y Militner, 2015; Vaidhyanathan, 2018.). Parte de la preocupación deriva de las dinámicas tecnológicas y mercantiles de los medios digitales, en las que - bajo una lógica neoliberal de maximización de ganancias- la cuantificación de clics o $\mathrm{Me}$ gusta retribuye en cantidades multimillonarias a sus dueños y en recompensas como la visibilidad para los usuarios; no importa que en ocasiones se valgan de conductas y contenidos cáusticos para lograrlo.

El presente trabajo analiza, a través de un acercamiento etnográfico de medios sociales, las diferentes prácticas y representaciones de identidad en línea que desarrollan algunos usuarios mexicanos de un grupo de discusión temática en Facebook, denominado Historia, el cual, adicionalmente, tiene una configuración de privacidad cerrada. Se descubrió que algunos integrantes de su comunidad recurren a conductas hostiles que podrían clasificarse como trolling o hating. Lo anterior dentro de procesos de configuración identitaria en línea que, además de dotarlos de visibilidad, les generan un sentido de pertenencia a partir de reducciones dicotómicas de la realidad, en torno a temas históricos y políticos de México, y el mundo. 
Un hallazgo adicional fue encontrar que una configuración de privacidad cerrada en un grupo de Facebook incidió, al menos en este caso, en reglamentos de comportamiento más laxos. Si bien los resultados no pueden generalizarse, se consideran un primer acercamiento al campo de una investigación que actualmente se realiza para el Doctorado en Ciencias Políticas de la Universidad Nacional Autónoma de México.

\section{Facebook en la vida de los mexicanos}

En México actualmente existen 71 millones 340 mil internautas (INEGI 2019). Resulta de sumo interés investigar cómo los mexicanos resignifican las prácticas globales de la comunicación digital. Destaca el caso de Facebook, plataforma de servicio comercial de socialización en línea que impulsa pautas de comportamiento con 2.3 mil millones de usuarios alrededor del mundo y 85 millones de cuentas en nuestro país, en donde cada suscriptor realiza un promedio de 11 Me gusta y 6 comentarios al mes, en cualquier publicación del sitio (We are social, 2019).

Dentro de su ecosistema existen 1000 millones de grupos temáticos dedicados a casi cualquier tópico, a nivel global (Facebook, 2019). En el caso de México es común el uso de grupos creados, entre otras cuestiones, a discutir sobre asuntos que van de la religión a temas de Historia universal o del país. Cualquier integrante de dichas comunidades puede publicar contenidos, sin necesidad de ser expertos en la materia, lo que propicia la circulación de mensajes basados en la creencia personal y el prejuicio. Un factor adicional es que algunos espacios tienen una configuración de privacidad cerrada, lo que significa que las interacciones que ahí se dan no pueden ser vistas por quienes no pertenezcan a dichas comunidades.

Lo anterior origina las preguntas del presente análisis: ¿Qué prácticas identitarias y de comunicación en línea puede propiciar un grupo de discusión sobre Historia en Facebook, que además tiene una configuración de privacidad cerrada? ¿Se tratará en su mayoría de comportamientos polémicos en los que sus integrantes se desenvuelven sin inhibiciones? ¿Cómo podrían clasificarse las 
conductas y contenidos que se dan dentro de un grupo de Facebook dedicado a temas históricos y políticos, y qué contribución pueden tener para la sociedad mexicana?

Con la finalidad de encontrar las respuestas, se despliegan los siguientes objetivos:

- Identificar las diferentes prácticas identitarias y de comunicación en línea que presentan los usuarios de un grupo sobre Historia, en Facebook.

- Establecer una tipología de los contenidos-simbólico narrativos de los participantes de un grupo sobre Historia, en Facebook, así como la visibilidad que obtienen sus publicaciones, tomando como referencia a las que más comentarios y reacciones generan.

- Identificar de qué forma construyen una imagen autorreferencial quienes realizan tales prácticas, a través de la configuración de sus perfiles y qué significados les generan.

\section{La tecnología digital conecta comportamientos}

Castells (2008), teórico de la Sociedad de la Información, denominó sociedades red a las sociedades capitalistas contemporáneas involucradas en procesos de globalización cultural, comunicativa y económica, a través de las tecnologías de la información y la comunicación (las TIC); en donde la estructura social se conforma por "aquellos acuerdos organizativos humanos en relación con la producción, el consumo, la reproducción, la experiencia y el poder expresados mediante una comunicación significativa codificada por la cultura" (pp.50-51). Aquí los individuos son nodos e interactúan compartiendo información y repertorios culturales.

Sin embargo, Latour (2007) en su Teoría del Actor-Red (TAR) se da a la tarea de expandir más el análisis sobre la estructura de las sociedades red al visibilizar a los diferentes actores, objetos y flujos de información que antes solamente se consideraban meros telones de fondo por la 
Sociología tradicional post-parsoniana. El filósofo y antropólogo francés retoma la metáfora dramatúrgica de Goffman ([1959]1997) para criticar la centralidad de la relación cara a cara en el interaccionismo simbólico, al considerar que en el escenario donde las personas despliegan la actuación de sus vidas cotidianas, igualmente intervienen una serie de factores que van desde los objetos y elementos técnicos -un micrófono, en caso de una conferencia, una computadora, en una oficina- a las reacciones del público.

La TAR redimensiona lo global. Lo concibe como redes de conexiones que circulan simultáneamente, de ida y vuelta, a través de circuitos específicos que conforman el entramado social, a manera de un sistema de tuberías neumáticas. Así, mientras lo macrosocial no se encuentra por encima de las acciones, sino que se agrega a ellas como una conexión más, lo local es redistribuido para estructurar y contextualizar diferentes sitios $^{11}$.

La tecnología informática, por su parte, es un actante más, no humano, que se planta en el escenario social y provee a los actantes humanos una amplia oferta de plug-ins de significados existentes que confeccionan subjetividades; algo semejante al filme The Matrix (Silver, 1999), cuando los protagonistas pueden descargar cualquier habilidad que deseen con tan solo conectarse a una terminal tecnológica, a modo de dispositivos de memoria vivientes.

Salvaguardando la distancia de los imaginarios tecno-futuristas creados por el ciberpunk, lo cierto es que el sociólogo de las asociaciones se pregunta: “¿cuántos clichés circulantes tenemos que absorber antes de tener la capacidad de dar una opinión acerca de un filme, un acompañante, una situación, una postura política?" (Latour, 2007, p. 297). Aterrizando tal cuestionamiento al contexto de los medios sociales, las redes sociodigitales son, sin duda, constructos que

\footnotetext{
${ }^{11}$ Latour (2007) pone a Wall Street como uno de los "centros de cálculo" del espíritu capitalista en cuanto se conforma como una red de flujos de millones de bits por segundo que circulan de ida y vuelta para determinar los estándares económicos y financieros del resto del mundo, pero que no deja de depender de múltiples eventos locales como las fallas de un sistema computacional al otro lado del mundo o el "movimiento traicionero de algún competidor" en Shanghái, Frankfurt o Londres (p. 256).
} 
proponen comportamientos entretejidos, a la vez, con las lógicas algorítmicas de sus interfaces, en un sentido de doble agencia, tanto humana como no humana.

Joshep M. Reagle (2015), académico de la Universidad North Eastern, en Boston, y especialista en estudios de Internet, distingue diferentes subculturas entre los usuarios de los medios sociales. Desde el fandom (aficionados a los productos de las industrias culturales), la lectura beta (práctica colaborativa en la que se comparten sugerencias para mejorar contenidos) o los likers: gurús influenciadores que prueban bienes y servicios para recomendarlos en sus blogs o vídeos en Youtube. Dentro de tal galaxia destaca el papel de los administradores: aquellos guardianes (gatekeepers) de las plataformas digitales-páginas, blogs o grupos de discusión en la web-, que se encargan de establecer los códigos de comportamiento entre sus integrantes para que se lleven a cabo en armonía. No obstante, a pesar de los esfuerzos de dichos personajes, se presentan prácticas incendiarias de las que destacan el trolling (conductas que enganchan a los demás en conflagraciones inútiles) o el hating: difusión de hostilidad y expresiones de odio en línea (Reagle, 2015). ${ }^{12}$

\section{Troles, Haters y otras criaturas extrañas}

El trolling tradicionalmente se considera una práctica disruptiva de la comunicación en línea (Donath, 1999; Dhalberg, 2001; Hardacker, 2010; Rafferty, 2011; MacKinnon y Zuckerman, 2012; Markey, 2013; Bishop, 2013; Reagle, 2015). Bajo esta óptica, la razón principal del trol sería valerse del anonimato y el engaño para provocar en los demás participantes de los foros reacciones emocionales orientadas al enojo, con el fin principal de lograr la diversión personal del confabulador. Se

\footnotetext{
${ }^{12}$ Se utiliza la denominación incendiaria para referirse a los contenidos cáusticos en la web. Sería una traducción aproximado del término flaming, el cual parece tener su origen en una colección llamada Flamewars (Dery, 1994) que analizaba este fenómeno cuando la Word Wibe Web era aún nueva. El término trolling también se remonta a los orígenes de la comunicación en línea. Aparece por primera vez en el estudio de Tepper (1997), sobre grupos de folklore urbano en Usenet. Por su parte, Bishop (2013) considera que el término hater es una variación del trolling que tomó popularidad después de que los medios masivos comenzarán la difusión de casos de troleo y ciberacoso a través de Internet, a finales de la primera década del año 2000.
} 
trata evidentemente de una connotación negativa en la que el término se torna difuso al usarse indiscriminadamente para abarcar casi cualquier comportamiento negativo dentro de Internet (Phillips, 2012; Markey, 2013; Bishop, 2013; Coles y West, 2016).

A pesar del prejuicio generalizado, Phillips (2012) considera que los troles no son sino el reflejo más descarnado de los mensajes mediáticos sensacionalistas de sociedades como la estadounidense, ya que se alimentan de los mismos para regurgitarlos en un proceso de digestión cultural. Bishop (2013) y Coles, y West (2016), por su parte, encuentran que no todo el trolling es malicioso, ya que existen manifestaciones de troleo complaciente que tiene el fin de propiciar la interacción de una comunidad en línea, aunque a veces resulte en disrupción. Habría también un trolling-anti-trolling (Phillips, 2012). Lo que para Coles y West (2016) consiste en una acción vigilante que se realiza de forma genuina por los no troles (o al menos usuarios no asumidos como tales) ..., para desalentar el acoso de otros troles a una comunidad. Finalmente, están los troles que fracasan en sus intentos de enojar a los demás, para ser motivo de diversión colectiva en el espacio digital que los arropa.

Ante la dificultad que implica el distinguir entre un trol y un genuino participante en un grupo de Internet, Coles y West (2016) señalan, desde el basamento de la psicología discursiva, que el trolling no debe ser considerado una etiqueta rígida, sino una actividad cuyos significados se negocian en el momento en que se dan las interacciones en línea. En otras palabras, los troles aparecen según la situación que se dé o, de acuerdo con Karppi (2013), trol es simplemente aquel que en determinado momento ejerce el trolling. Para efectos del presente trabajo, se parte de la concepción básica de trolling, la que en palabras de Bishop (2013) consiste en publicar un mensaje diseñado para provocar una reacción en los demás, generalmente afectiva. Dependerá de las diferentes etapas del estudio de campo aquí desarrollado, el establecer si efectivamente se trata de troles o acciones de troleo.

Otra tipología por considerar es el hating, derivado del troleo más ofensivo (snert trolling), aquel que, de acuerdo con Bishop (2013), tiene la finalidad de intimidar a algún objetivo o persona específica. Amaral y Monteiro (2013) observaron en grupos de Facebook que los haters 
basan sus interacciones en el odio manifiesto. Según Bishop (2013) el hater actúa a partir del resentimiento hacia quienes considera que no tienen las expectativas suficientes para ser exitosos o notables, por eso sus ataques suelen dirigirse a personajes famosos; cantantes de rock en el caso del estudio de Amaral y Monteiro (2013).

Evidentemente, tanto el trolling y el hating parten de contenidos incendiarios dentro del contexto de las redes sociodigitales. Sin embargo, lejos del enfoque negativo sobre sus efectos, es imprescindible comprenderlos en cuanto prácticas construidas a partir del cruce de significados, que configuran parte de una identidad en línea a quienes las desarrollan. ${ }^{13}$ Se entiende a la identidad en línea en su acepción clásica de representación gestionada, e inseparable de la identidad real (Papacharissi, 2010; Yus, 2010; Sibilia, 2012; SerranoPuche, 2012; Trejo, 2014), pero tecnológicamente mediada por algoritmos e interfaces de artefactos socio-tecno-culturales existentes dentro de una sociedad red y que proporcionan diferentes formas de sentido (Cheney-Lippold, 2011; Karppi, 2013; Van Dijck, 2013; Bucher, 2013).

\section{Las democracias, los troles y los afectos}

Existen investigadores (Burroughs 2013; Milner 2013; McCosker, 2014) que ven en el trolling un incentivo de la participación ciudadana en torno a problemas públicos que, si bien no alcanzan el nivel de una democracia deliberativa en el sentido de Habermas (1987), sí pueden llegar - bajo determinadas condiciones - a la construcción de una democracia agonística, en términos de Mouffe (2000), quien hace del conflicto un recurso de participación pública plural. Dahlberg (2007), vislumbra en el conflicto en la web un campo de lucha política a través del discurso, aunque cuestione los significados y prácticas de las esferas públicas dominantes.

\footnotetext{
${ }^{13}$ Nick Couldry (2004) entiende las prácticas como actividades rutinarias que no son solo entendimientos explícitos, sino también objeto de normas comunes en las que se comparte el punto de referencia de ciertos fines, proyectos o creencias; a su vez, propone entender los medios de comunicación a través de las prácticas que las personas realizan en torno a ellos y las representaciones del mundo social que los primeros construyen.
} 
Papacharissi (2015) aborda las estructuras de sentimiento con las que los públicos emergentes de la comunicación en red remontan a convenciones compartidas que reflejan el estado de ánimo de una época y convocan a la participación cívica con base en elementos afectivos. Los afectos y el sentimiento definen así modalidades de sentido de pertenencia que se articulan a medida que los extraños se conectan entre sí. Por ende, las sintonizaciones afectivas permiten a las personas llegar a lo político cuando se convierten en colectivos que evolucionan a partir de la interacción tecnológica. La investigadora de la Universidad de Illinois destaca una materialidad mediada por algoritmos que representan gestos afectivos y permiten desarrollar narrativas de conexión o discordia.

Un recurso para compartir afinidades en línea es la forma en que elaboramos una representación de nosotros mismos en las redes sociodigitales, tomando elementos simbólicos de su arquitectura que nos sirvan de marcos de referencia para conectar con los demás, en procesos de homofilia ideológica, política, cultural o de otra índole.

\section{La presentación de la persona en las redes sociodigitales}

Karppi (2013) y Van Dijck (2013) retoman a Goffman (1997) y la presentación del yo en la vida cotidiana, para explicar configuraciones de identidad en línea que, además, se complementan con una confección tecnológica de los procesos de comunicación mediada por un computador.

En Facebook existen los perfiles, interfaces con las que los individuos se representan conforme una serie de signos —avatar, portada o información - sobre la imagen que quieren proyectar a los demás (Apariencia, en términos goffmanianos). ${ }^{14} \mathrm{~A}$ su vez, las interacciones en el sitio son modales con los que desempeñan rutinas basadas en hábitos o estereotipos preestablecidos: una jerga, una conducta o el uso de memes, entre otros signos, y se materializan en publicaciones y

\footnotetext{
${ }^{14}$ Esto, de acuerdo con quienes han retomado el concepto de Fachada (Goffman,1997) para analizar las redes sociodigitales (Serrano Puche, 2012; Iturralde, 2016). La Fachada se divide en Apariencia (signos que denotan un estatus social, como insignias, títulos académicos, una vestimenta) y Modales (Roles de interacción, como una jerga al hablar, por ejemplo).
} 
comentarios. ${ }^{15}$ Tanto apariencia y modales conforman una fachada confeccionada conscientemente por el usuario, pero se integra con signos inconscientes de identidad que, para Van Dijck (2013) en el caso de las redes sociodigitales, se dan por los algoritmos.

Otro espacio simbólico en la interfaz de Facebook son los grupos temáticos, creados para "intercambiar opiniones acerca de intereses comunes con determinadas personas" (Facebook, 2018). No obstante, parte de dicho intercambio se hace mediante fachadas cáusticas. En grupos dedicados a la Historia, por ejemplo, suelen existir discursos alimentados por un falso revisionismo histórico que, a decir de Montesinos (2007), se aleja del ámbito académico para basarse en principios políticos y de manipulación ideológica. Por ejemplo, se han detectado en Facebook nichos dedicados a discursos radicales, como el supremacismo (Vaidhyanathan, 2018), o que ensalzan formas autoritarias de gobierno, por ejemplo: el nazismo (Buezas, 2012)

Por otro lado, Phillips (2012) observa que los relatos de privilegio blanco patriarcal son una característica inherente en el comportamiento de los troles. En grupos de discusión temática en Facebook compuestos por usuarios mexicanos se han detectado espacios dedicados al trolling u hostilidades y discriminación hacia fenómenos culturales relacionados con las clases populares, como el culto a la Santa Muerte o la música reguetón (Pérez, Gervasi y Cuevas, 2015; Pérez y Hernández, 2017; Pérez, Bravo y Del Bosque, 2018).

El universo de estudio del presente proyecto es el grupo Historia, espacio creado por administradores mexicanos en 2012 con el propósito de debatir sobre temas de Historia y política. Al momento del análisis de campo, cuenta con una comunidad de 14, 230 internautas y un nivel de interactividad del 76.39 por ciento; es decir, tres de cada cuatro publicaciones generan comentarios y reacciones

${ }^{15} \mathrm{El}$ meme es producto de la cultura trol. Es definido por Knobel y Lankshear (2007) como "un término popular para describir la rápida adopción y difusión de una idea particular presentada como un texto escrito, imagen, lenguaje en 'movimiento', o alguna otra unidad de 'material' cultural"(p. 202). 
(Grytics, 2017). Se trata de un grupo de Facebook cuya privacidad se encuentra cerrada ${ }^{16}$.

Llama la atención que, desde la etapa de observación participante previa al estudio de campo, se detectaron en el grupo Historia contenidos polémicos no basados en fuentes arbitradas sino en páginas, blogs y memes caracterizados por el sentido común o la creencia personal. Dichos contenidos parecen ser inherentes a conductas incendiarias, reacciones afectivas y formación de bandos tribales por parte de la comunidad del sitio, a partir de una reducción binaria de la realidad. Dicha representación iría en sentido de una lógica de disputa entre conservadores y liberales, fenómeno que caracterizó al desarrollo de México a lo largo de su historia y que, aunque era algo que se creía concluido, se puede deber a los efectos de una Historia oficial que produce héroes y villanos de bronce (Fernández, 2015) o al discurso maniqueo de un conservadurismo radical (Montesinos, 2007) emanado - en el caso de México, un estado laico- de la derrota cultural de la derecha mexicana. Ya sea por una razón u otra, los integrantes del grupo Historia parecen generar homofilias o discordias con base en representaciones estereotípicas del presente y el pasado.

De esta manera, el ecosistema digital parece terreno fértil no solo para la circulación de contenidos incendiarios. Igualmente puede resucitar viejos discursos enterrados en el panteón de la corrección política. Esta el ejemplo de las elecciones presidenciales de los Estados Unidos, en las que la campaña del entonces candidato Donald Trump reavivó los sentimientos de una minoría representada en Internet por grupos como alt-right, colectivo de ultraderecha compuesto por una legión de troles, blogueros y tuiteros anónimos que piensan que la identidad blanca y cristiana peligra en los Estados Unidos (Stein 2016).

\footnotetext{
${ }^{16}$ Cuando se crea un grupo en Facebook se pueden seleccionar tres configuraciones de seguridad para el mismo: Público (todo el mundo puede unirse y ver las publicaciones de los demás); Cerrado (solo pueden unirse los que son aceptados por los administradores o agregados por otros miembros del grupo y los contenidos solo puede verlos su comunidad); y Secreto (solo pueden unirse los que son agregados o invitados por otros miembros y nadie, salvo sus integrantes, puede ver los contenidos o saber sobre la existencia del grupo).
} 


\section{Metodología}

El presente análisis utilizó un enfoque etnográfico de medios sociales, en el que los actos performativos en línea de los individuos están coimplicados con artefactos culturales que involucran procesos más amplios de su vida presencial, hibridando así sus prácticas sociales (Postill y Pink, 2012). El primer paso consistió en un ejercicio de observación participante, al ser integrante del grupo desde hace tiempo; le siguió un análisis de lo que la herramienta Grytics consideró las 10 publicaciones con más peso durante un mes (30 de octubre al 29 de noviembre de 2017), ${ }^{17}$ periodo suficiente para estimar que son las más visibles, aunque cabe señalar que se trata de una muestra sesgada por los rangos de esa herramienta. ${ }^{18}$ Además, no se trata de una muestra significativa, sino de un corpus de datos complementado por un análisis de redes semánticas, un análisis de contenido de los perfiles de los participantes y cuestionarios con preguntas semi-abiertas contestadas en línea por 15 integrantes del grupo.

El análisis de redes semánticas (Kim, 2011) estudia la relación entre redes de pensamientos condensados en sustantivos, poniendo énfasis en los marcos explícitos e implícitos de un contexto sociopolítico específico. Requiere un trabajo de interpretación del investigador. La meta principal de las redes semánticas es encontrar la co-ocurrencia entre nodos en contextos de palabras clave que transfieren significados a otros nodos, que a su vez los interpretan con una lectura propia (Un objeto A se infiere o se piensa dentro del contexto del objeto B). Esto se da entre diferentes constelaciones que se conectan entre sí alrededor

\footnotetext{
${ }^{17}$ Cabe destacar que la operación se pudo hacer gracias a uno de los administradores del grupo Historia, sin cuya ayuda no se podría haber concretado el trabajo de campo ni la extracción de algunas estadísticas mediante una herramienta como Gritycs, diseñada para que Community Managers obtengan información sobre los movimientos y actividad en sus páginas y grupos de Facebook.

${ }^{18}$ De acuerdo con la métrica de Grytics, la ecuación para calcular el récord de las publicaciones más visibles (Posts Engagement Score) es dos veces el número de comentarios recibidos en la publicación + su número de reacciones.
} 
de los nodos clave en un modularidad dividida en diferentes temáticas ${ }^{19}$.

Para el análisis de contenido de los perfiles se retoma la noción de Fachada de Goffman (1997) en la que los signos de un perfil de Facebook componen una imagen del usuario, que sin embargo se complementa con los algoritmos del sitio (Van Dijck, 2013). Por último, como parte de las implicaciones éticas de la investigación se conservan en el anonimato las identidades y avatares con rostro de quienes formaron parte del universo de análisis.

\section{Resultados}

Un primer resultado de la investigación de campo fue un hallazgo afortunado. Al hacerse la búsqueda de selección del universo de análisis, en una primera etapa de observación participante, se encontró una ausencia casi total de mensajes y comportamientos polémicos en grupos de Historia en Facebook con una configuración de privacidad abierta, muy probablemente debido a dos factores:

1. Reglamentos más rígidos. Mientras que en la normatividad de Historia se permite que los fines de semana se publiquen 'Temas como chistes, videos de canciones, juegos, troleo y cualquier contenido ajeno a los temas del foro", en otros lugares como "Historia Universal (Arqueología - Mitología y Arte- Lugares -

${ }^{19}$ Dado que denotación es el significado literal o central de un signo y una connotación se refiere a significados secundarios asociados con ella, la teoría de la connotación parece ser la herramienta más apropiada para el descubrimiento de capas de significado "ocultas" en el mensaje basado en el conocimiento cultural asociado. Esta traducción semántica del análisis de la red social es posible porque los nodos relevantes (correspondientes) heredan esencialmente los roles funcionalmente prominentes: un nodo con la centralidad de mayor interrelación asume el rol de mediador de la comunicación, ya que se requiere que se represente explícitamente a sí mismo. Puente de diferentes grupos de conceptos. En comparación, un concepto clave con la mayor centralidad de entrada-cercanía es "connotativo" porque es el resultado final de la interacción comunicativa que se coloca más cerca del centro de referencia (Kim, 2011, p. $5)$. 
Astronomía)", se advierte que, en cuestión de "Comentarios agresivos: Se elimina el comentario y se bloquea al miembro" ${ }^{20}$.

2. La configuración de privacidad. La diferencia entre un grupo público de Facebook y uno cerrado pareció ser un factor significativo en los contenidos de los sitios.

\section{Troles, Haters, Administadores y Deliberadores}

El trabajo de campo se hizo conforme al orden de los objetivos específicos de la investigación. Primero se seleccionaron las 10 publicaciones con más peso durante el periodo de un mes (del 30 octubre al 29 de noviembre, de 2017) de acuerdo con Grytics (2017), ${ }^{21}$ para analizar el contenido de estas. Se encontraron cuatro tipologías principales de prácticas de la comunicación en línea: Administradores (tres publicaciones); Trolling (tres publicaciones); Hating (dos publicaciones); y Deliberativos (dos publicaciones).

\section{Gráfico 1. Tipología de las 10 publicaciones con más peso de} noviembre de 2017 en el grupo Historia

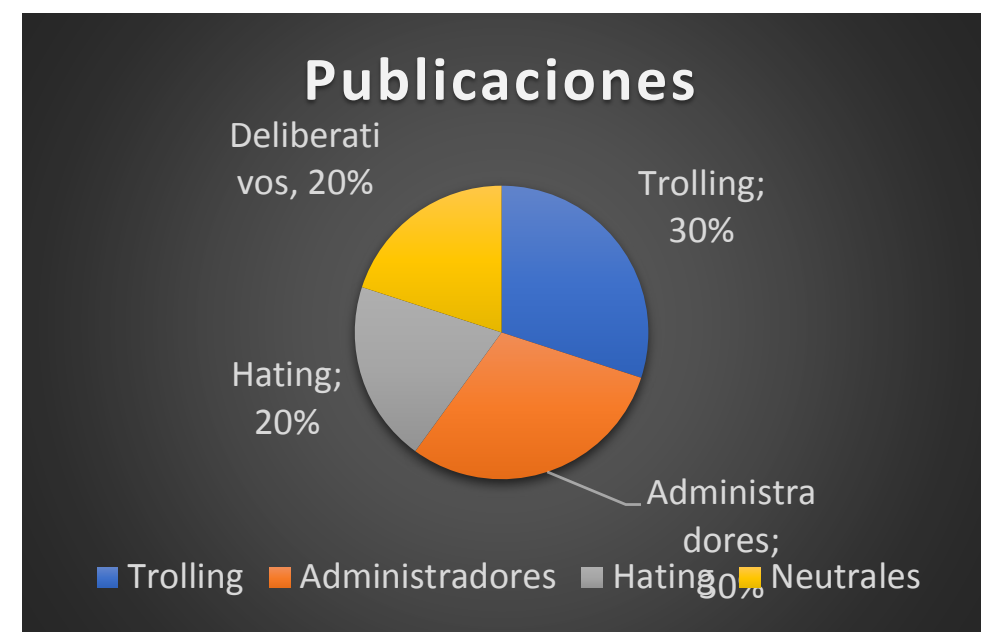

Fuente: elaboración propia

\footnotetext{
${ }^{20}$ Véanse íntegros los reglamentos del grupo Historia e Historia Universal (Arqueología - Mitología y Arte- Lugares - Astronomía):

https://www.facebook.com/groups/537005286325452/permalink/102385858 0973451/ y https://www.facebook.com/groups/1168309043262188/

${ }^{21} \mathrm{Si}$, como afirma Stein (2016), quienes desempeñan el trolling en Internet aseguran que es una conducta que empodera y genera adicción a la visibilidad, esta última es una categoría clave para trazar el presente análisis.
} 
De un total de $\mathrm{N}=1167$ comentarios generados por las 10 publicaciones, el 47 por ciento se componen por contenidos afectivos (adjetivaciones, sobrenombres, insultos y risas de burla), 50 por ciento mensajes de deliberación sobre los temas publicados y tres por ciento se clasificaron como otros (mensajes cuyo sentido no quedó claro).

Las publicaciones que más comentarios y reacciones generaron fueron aquellas con contenidos incendiarios: Hating, 445 comentarios (69 por ciento de ellos afectivos); y Trolling, 355 comentarios (el 49 por ciento, afectivos). Deliberativos y Administradores generaron más mensajes de diálogo.

\section{Gráfica 2. Categorías de las publicaciones con más reacciones y comentarios}

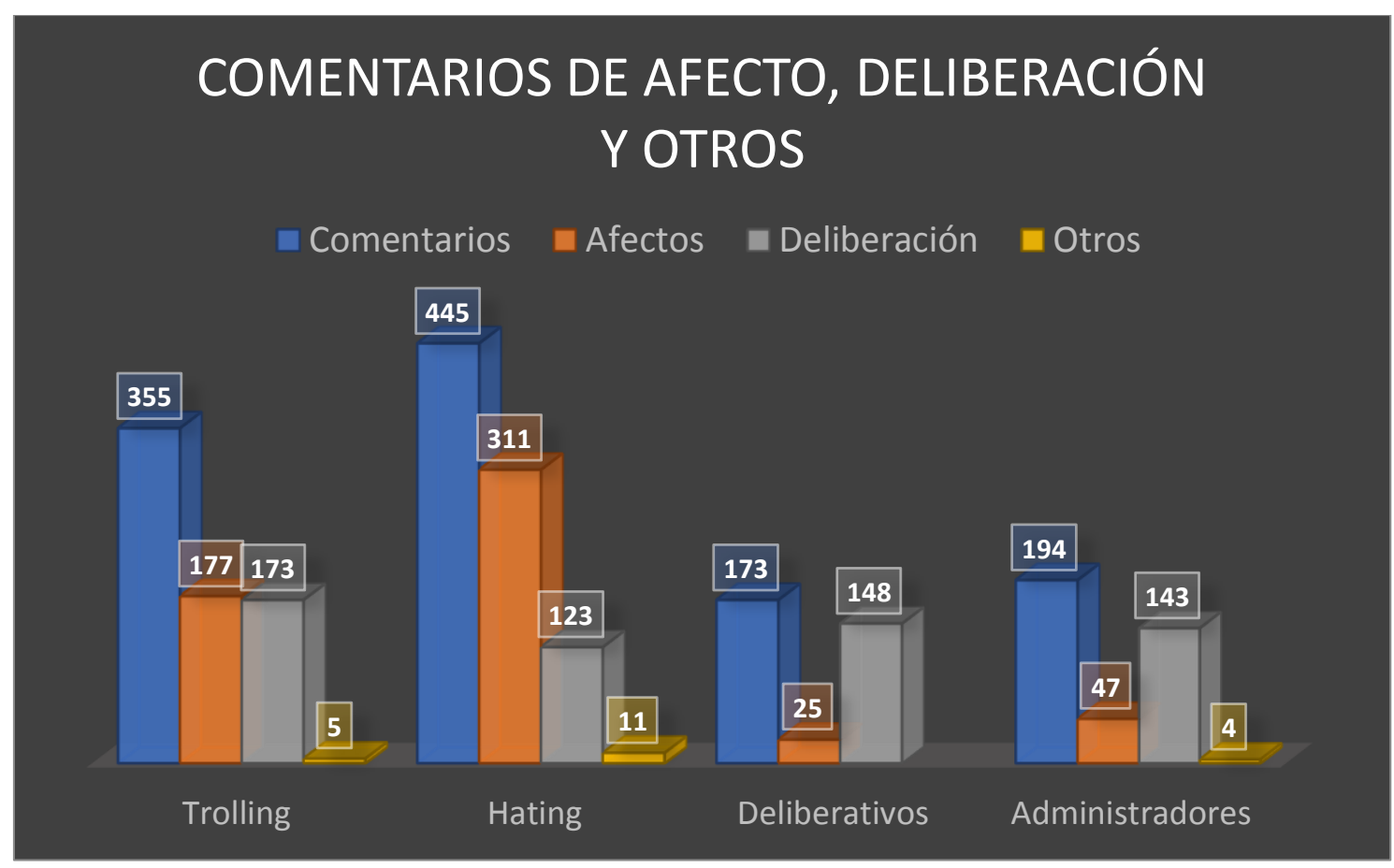

Fuente: elaboración propia

Las publicaciones con contenidos incendiarios obtuvieron más resultados afectivos como Me enoja o Me divierte. Mientras que las que se clasificaron Administradores tuvieron más Me gusta y Me divierte. Los Deliberativos, tuvieron más Me gusta. 
Gráfica 3. Categorías de las publicaciones y el tipo de reacciones que generaron

\begin{tabular}{l|c|c|c|c|c|c|}
\multicolumn{1}{c}{ Reacciones a las publicaciones } \\
ME ENTRSTECE \\
ME GUSTA
\end{tabular}

Fuente: elaboración propia

Se denominó Trolling a prácticas de usuarios que suben contenidos polémicos derivados en comentarios afectivos. Un ejemplo sería: "España no cometió ningún genocidio: lo que hizo fue poner fin a uno", cuyo argumento asegura que la versión del genocidio durante la Conquista española en América es un mito perpetrado por "la extrema izquierda" y, por el contrario, los españoles vinieron a civilizar a los indígenas, quienes eran los verdaderos genocidas.

\section{Imagen 1. Publicación de Trolling en el grupo Historia de} Facebook

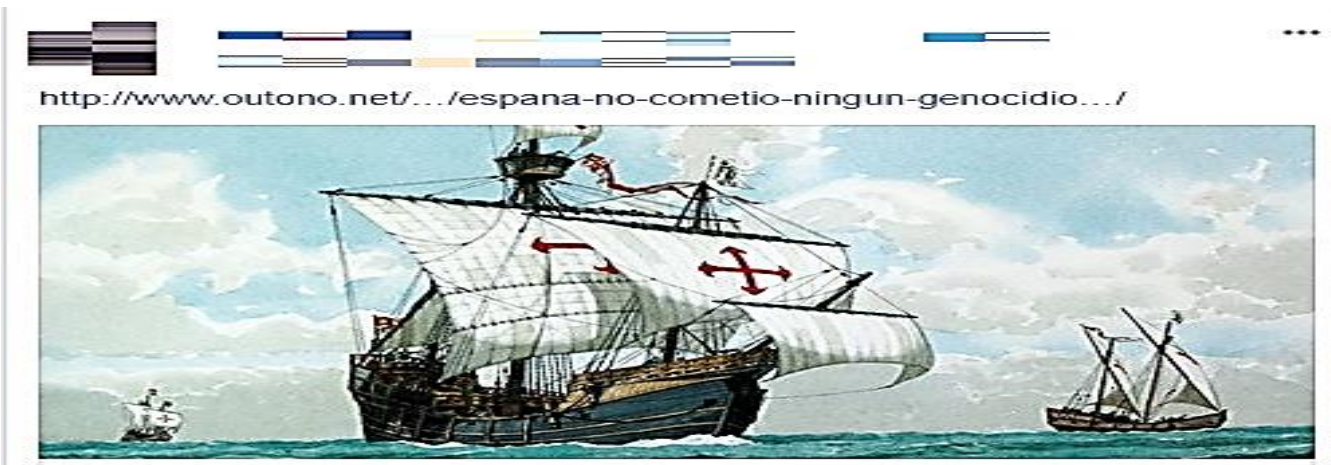

España no cometió ningún genocidio en América: lo que hizo fue poner fin a uno

Uno de los mitos históricas que con más insistencia repiten algunos, en especial la extrema izquierda, es la supuesta existencia de un "genocidio" perpetrado por.

OUTONO.NET

W Me gusta $\varnothing$ Comentar

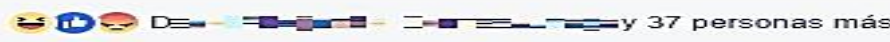

Fuente: captura de pantalla 
Si bien, el proceso de la Conquista española no fue de exterminio total hacia las etnias locales, el posteo se caracteriza por un contenido conocido comúnmente como hispanista por usuarios mexicanos de las redes sociodigitales y ejemplifica las narrativas que Montesinos (2007) considera de negacionismo, además de contener una carga racista fundamentada en un darwinismo social. El 62 por ciento de comentarios al mensaje fueron afectivos, con una posición radicalmente opuesta, como puede observarse en la siguiente imagen:

\section{Imagen 2. Comentarios de reacciones afectivas a una publicación considerada trolling}

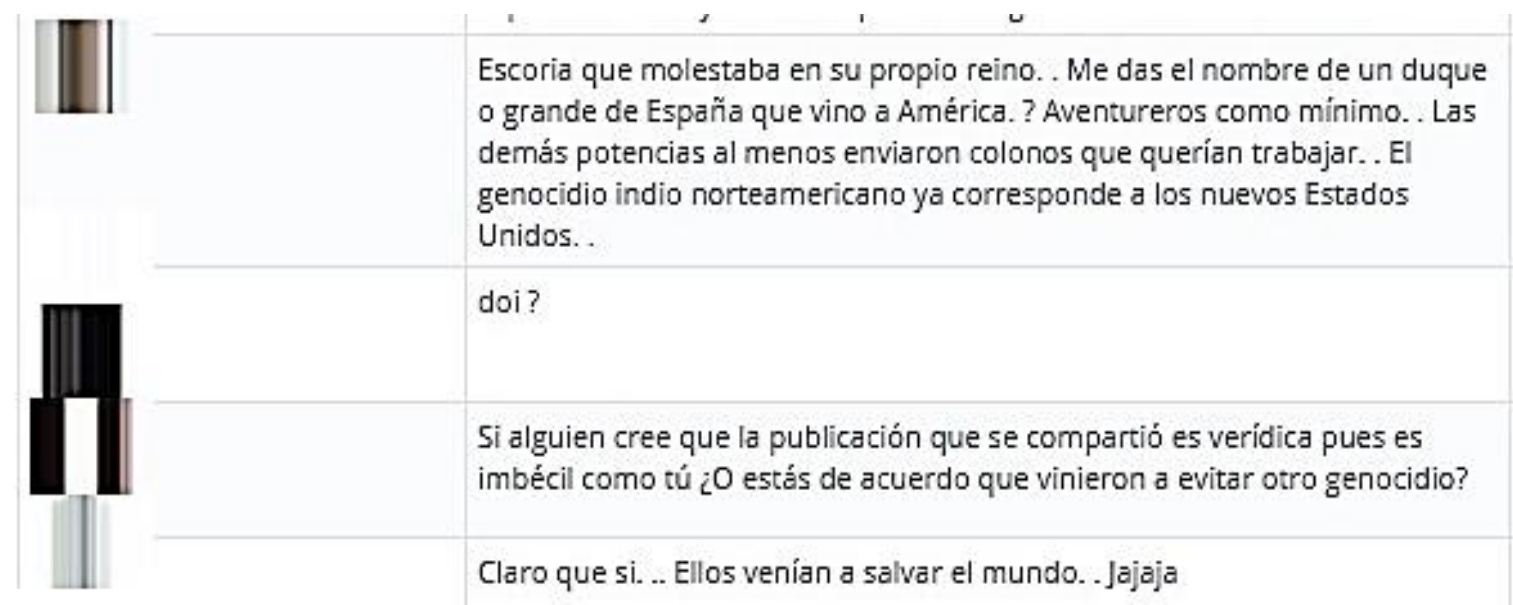

Fuente: captura de pantalla

Se denominó Hating a dos publicaciones: contenidos cargados de una animadversión explícita, generalmente dirigida contra un objetivo específico (una persona o sector social). La publicación con más peso de la muestra fue un meme dirigido a la videobloguera guatemalteca, Gloria Álvarez, figura de los medios sociales que representa los ideales de un criollismo latinoamericano que legitima los discursos neoliberales y de las élites de poder global. La imagen del meme considera al movimiento conservador libertario o de "Nueva Derecha", la "escoria del mundo intelectual". ${ }^{22}$ Se incluye de referencia una foto de Gloria

\footnotetext{
${ }^{22}$ El Libertarismo o mejor conocido como Conservadurismo Libertario, es un movimiento que pugna por la defensa de cuestiones como la propiedad privada, una mayor libertad económica y una menor intervención del Estado en los asuntos públicos y privados de una sociedad.
} 
Álvarez y una cita de la filósofa Ayn Rand. La publicación generó 338 comentarios, 73 por ciento de ellos, afectivos.

\section{Imagen 3. Meme sobre la videobloguera Gloria Álvarez}

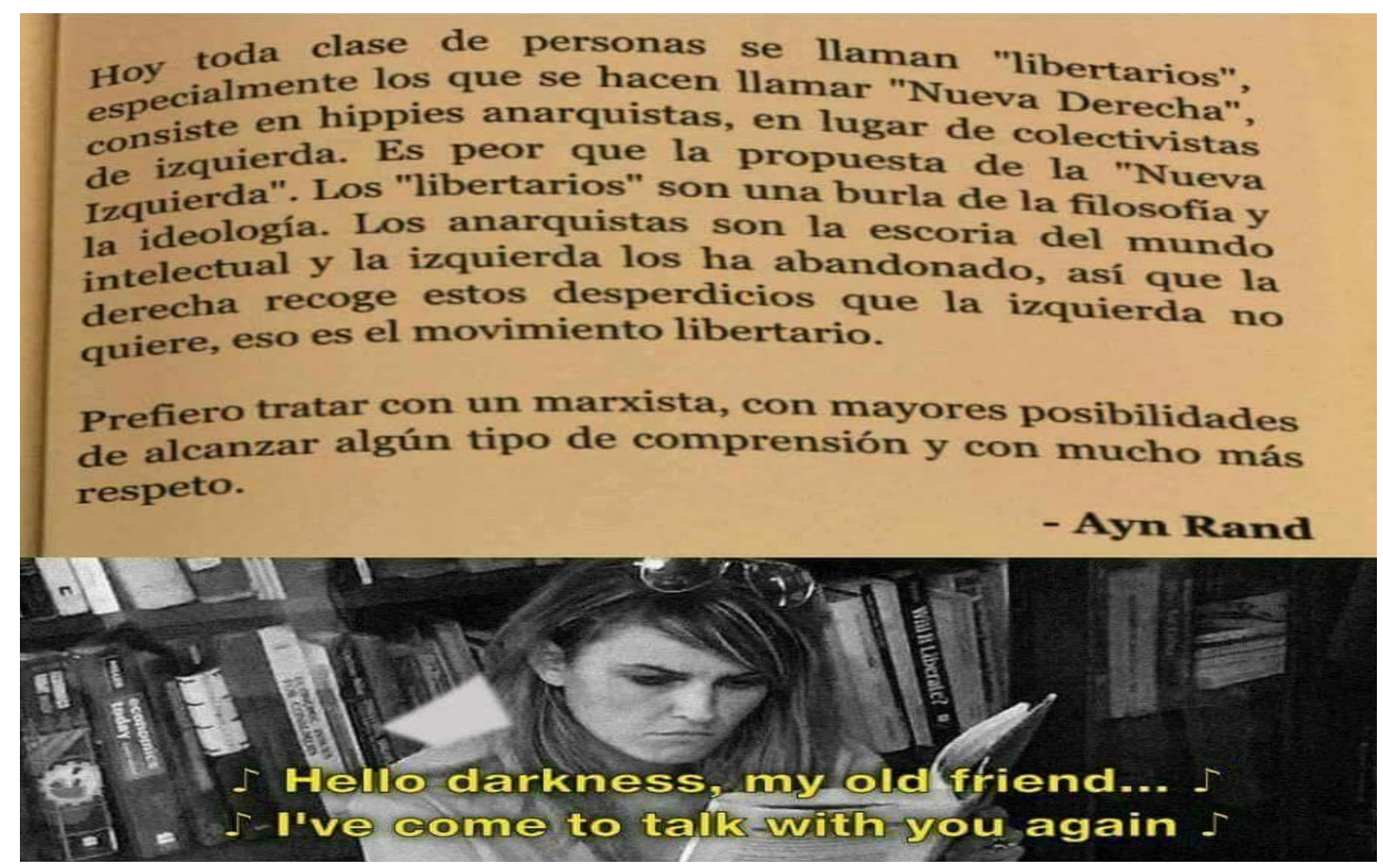

Fuente: captura de pantalla

Administradores: categoría que se conformó por tres publicaciones de una mujer cuyo perfil detenta la jerarquía de moderadora del grupo. Ella hizo dos publicaciones con temas de interés deliberativo, una de ellas algo provocadora: un vídeo sobre la intolerancia de un líder cristiano hacia la comunidad gay. Generó 52 por ciento de mensajes afectivos por parte de haters conservadores y derivó en connotaciones como "Maricones", "Mañosos" o "Antinatural". Un ejemplo de los mensajes es el siguiente meme, en el que se mira a un integrante del movimiento Lésbico-Gay (LGTT'TB) con la bandera representativa del mismo clavada en el trasero. 
Imagen 4. Meme con el que un hater respondió a una publicación de la moderadora sobre derechos de la comunidad LGTTTB

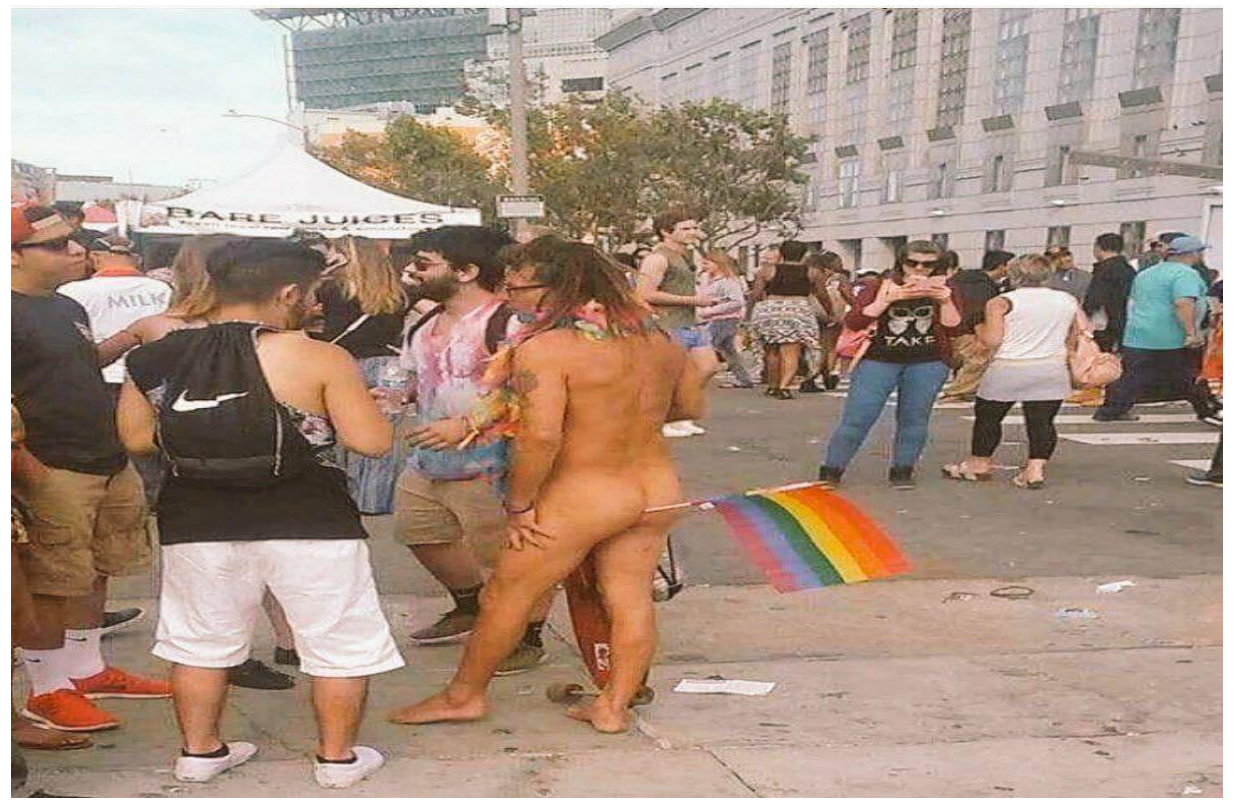

Fuente: captura de pantalla

Sorprendentemente, otro contenido de la moderadora es de Hating, igualmente dirigido a Gloria Álvarez. Un Meme donde, supuestamente, Karl Marx la llama "alienada de mierda". Por supuesto, la autora de la publicación no avala explícitamente el contenido, lo pone a debate al hacer la pregunta "¿Quién tiene la razón?" Su posteo obtiene el 26 por ciento de mensajes afectivos.

Imagen 5. Otro meme dirigido a la Videobloguera Gloria Álvarez

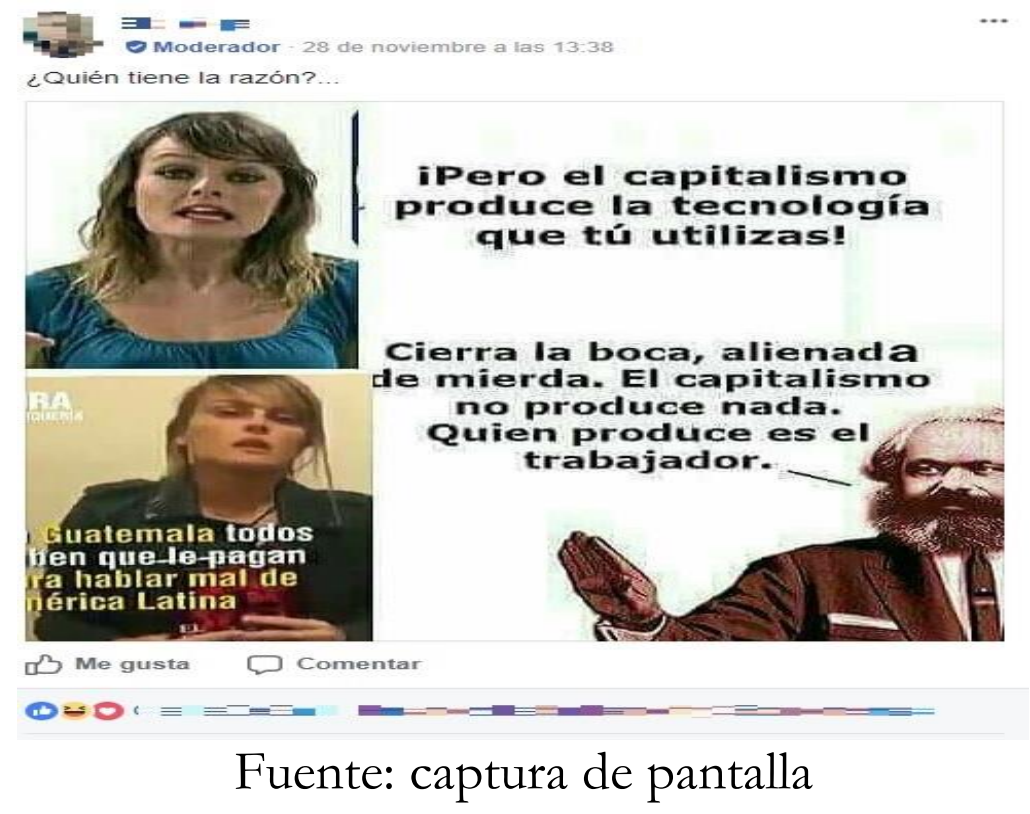


Una última tipología se calificó Deliberativos: gente que sube contenidos de interés sin mayores sesgos ideológicos o juicios de valor explícitos. Por ejemplo, fotos de Villa y Zapata o notas sobre cultura y religión. El 85 por ciento de los comentarios adscritos son de debate.

\section{Imagen 6. Publicación con contenido Deliberativo}

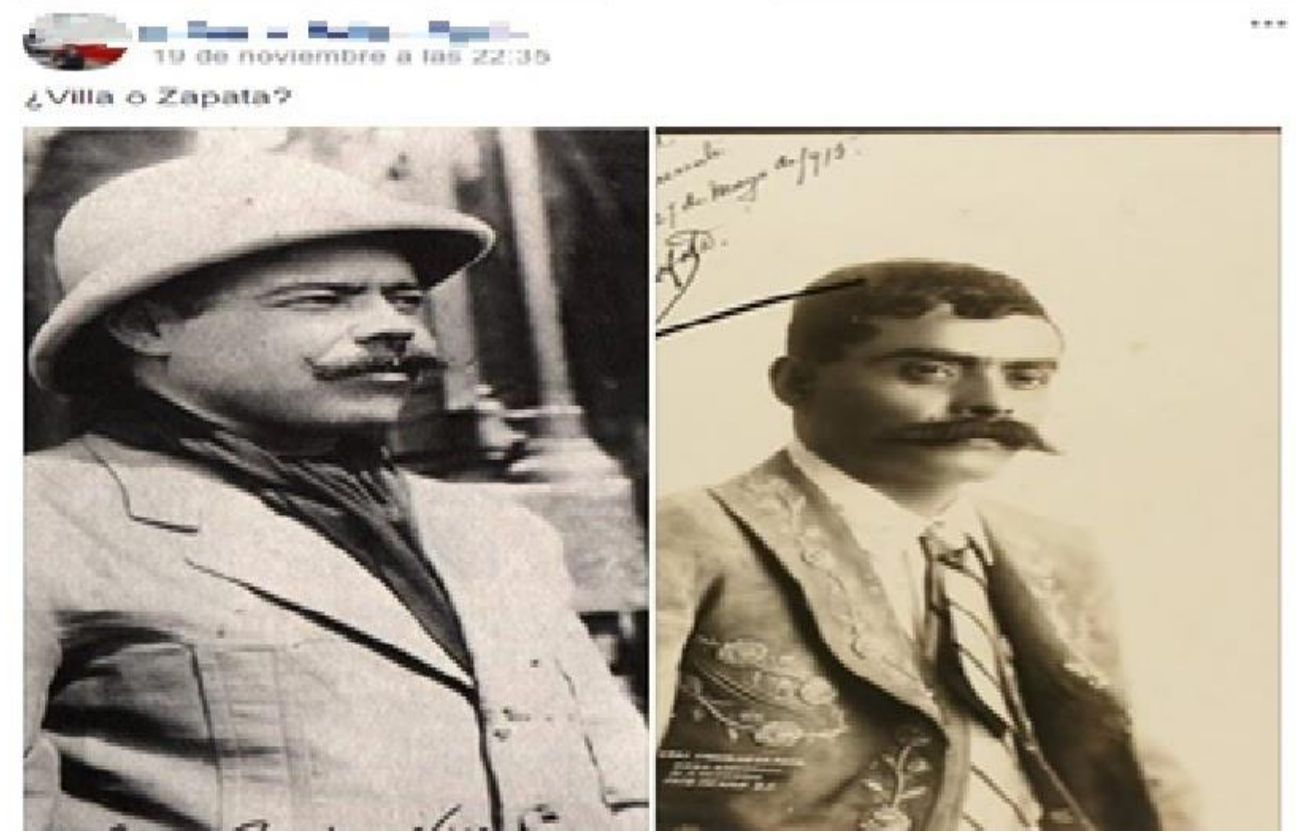

Fuente: captura de pantalla

\section{Chairos, derechairos, Liberpobres y Feminazis}

A partir de las 10 publicaciones analizadas y 1167 comentarios aleatorios se construyó una red semántica que resultó en 267 nodos y 306 aristas con siete temas que aglomeran constelaciones de percepciones afectivas y deliberativas.

Cada tema de las publicaciones son nodos de salida, con un grado medio de 1,146, que denotan múltiples significados en los actantes al momento de conectar con ellos. Llama la atención que cuando son contenidos incendiarios se detonan términos que corresponden a una jerga específica de los internautas mexicanos, la cual - a la vezsignifica denostaciones del otro a partir de posiciones ideológicas binarias ubicadas a ambos extremos del espectro político. 
Imagen 7. Red Semántica de contenidos de Deliberación y Afectos

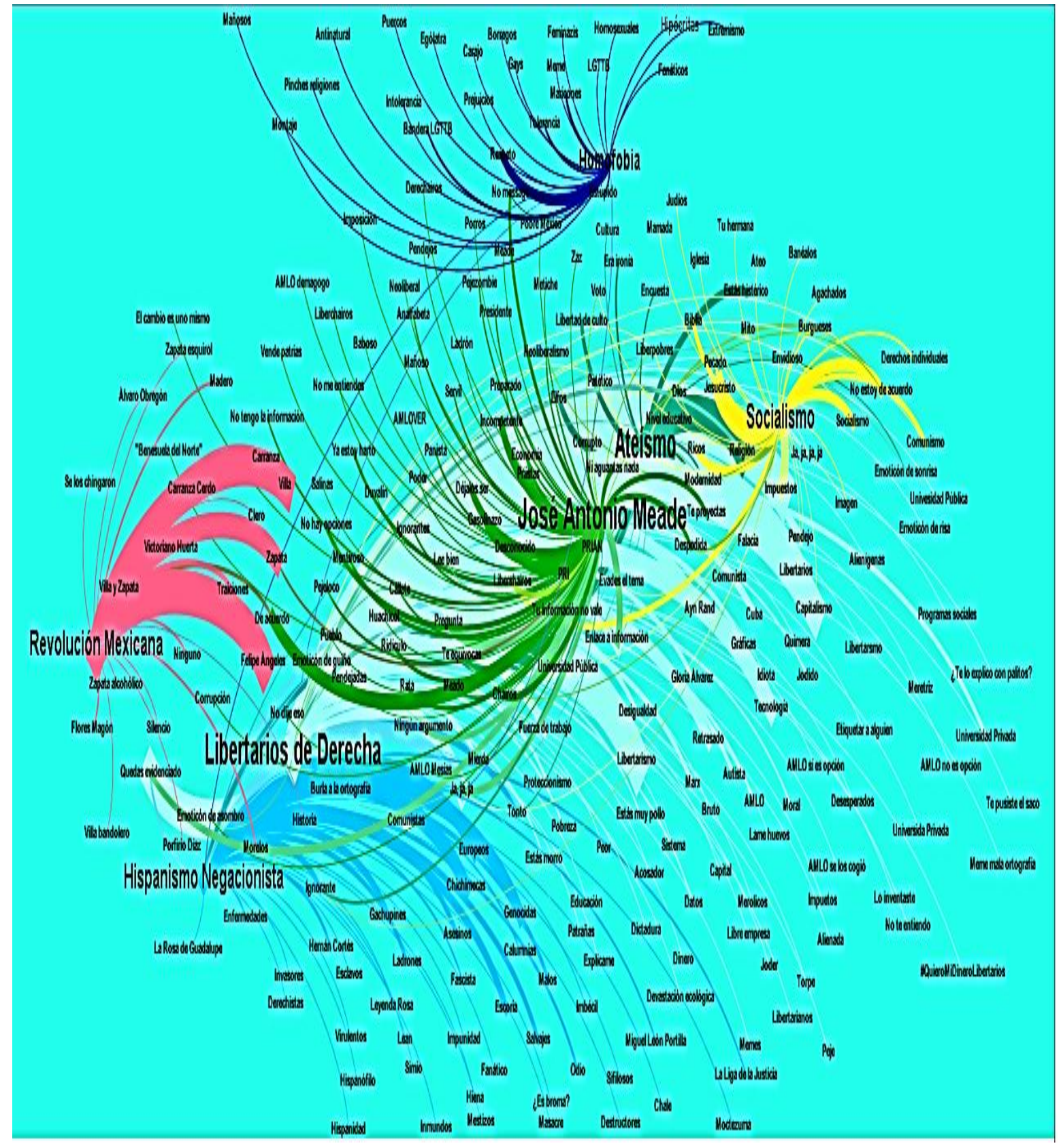

Fuente: elaboración propia 
Tabla 1. Modelo de bloques de co-ocurrencias semánticas entre conceptos

\begin{tabular}{|c|c|c|c|c|}
\hline $\begin{array}{l}\text { Nodo } \\
\text { temático de } \\
\text { salida } \\
\text { (Denotación) }\end{array}$ & $\begin{array}{l}\text { Nodos de } \\
\text { entrada o } \\
\text { términos } \\
\text { asociados con } \\
\text { posiciones } \\
\text { conservadoras } \\
\text { (Connotación) }\end{array}$ & $\begin{array}{l}\text { Peso o } \\
\text { Frecuencia }\end{array}$ & $\begin{array}{l}\text { Nodos de } \\
\text { entrada o } \\
\text { términos } \\
\text { asociados con } \\
\text { posiciones } \\
\text { liberales } \\
\text { (Connotación) }\end{array}$ & $\begin{array}{l}\text { Peso } \\
\text { o } \\
\text { Frecuencia }\end{array}$ \\
\hline \multirow{3}{*}{$\begin{array}{l}\text { Hispanismo } \\
\text { Negacionista }\end{array}$} & Fascista & 2.0 & & \\
\hline & Fanático & 1.0 & & \\
\hline & Hispanófilo & 1.0 & & \\
\hline \multirow[t]{5}{*}{ Homofobia } & Fanáticos & 1.0 & Maricones & 3.0 \\
\hline & Hipócritas & 1.0 & Mañosos & 1.0 \\
\hline & Extremistas & 1.0 & Antinaturales & 1.0 \\
\hline & & & Feminazis & 1.0 \\
\hline & & & Borregos & 1.0 \\
\hline \multirow{6}{*}{$\begin{array}{l}\text { José Antonio } \\
\text { Meade }\end{array}$} & Prianistas & 12.0 & Chairos & 5.0 \\
\hline & Priístas & 7.0 & Pejezombies & 2.0 \\
\hline & Libershairos & 4.0 & Amlovers & 1.0 \\
\hline & Liberchairos & 1.0 & Serviles & 1.0 \\
\hline & Derechairos & 1.0 & & \\
\hline & Liberpobres & 1.0 & & \\
\hline \multirow{5}{*}{$\begin{array}{l}\text { Libertarios } \\
\text { de Derecha. }\end{array}$} & Libertarios & 27.0 & Comunistas & 15.0 \\
\hline & Libershairos & 6.0 & Chairos & 1.0 \\
\hline & Libertarianos & 5.0 & & \\
\hline & Liberpobres & 1.0 & & \\
\hline & Lamehuevos & 1.0 & & \\
\hline \multirow[t]{2}{*}{ Socialismo. } & Libershairos & 4.0 & Envidiosos & 1.0 \\
\hline & Liberpobres & 1.0 & & \\
\hline
\end{tabular}

Varios de los temas de la muestra de análisis están condicionados por el contexto del periodo de estudio, en noviembre de 2017. A finales de ese mes se postuló a José Antonio Meade como candidato del entonces partido oficial, el Revolucionario Institucional (PRI), a la Presidencia de México para las elecciones 2018. La noticia derivó en publicaciones incendiarias que generaron términos despectivos hacia usuarios relacionados con partidos orientados a la derecha (Prianítas, Priístas), 
o contra los simpatizantes del entonces candidato con orientación a la izquierda, Andrés Manuel López Obrador (Pejezombies, Amlovers).

Otras formas peyorativas para dirigirse a personas con una posición ideológica es Chairos (gente defensora de las causas liberales pero que se considera radical o poco comprometida); Derechairos (radicales de derecha o clasemedieros aspiracionales); Feminazis (mujeres feministas); o las variantes que designan a simpatizantes del Liberalismo Conservador (Libertarios, Libertarianos, Libershairos, Liberchairos, Liberpobres).

\section{Confrontando al otro, al diferente}

Algunos de los usuarios entrevistados consideraron que una de las razones principales para confrontar al otro se debe al hecho de tener creencias diferentes a las suyas, por posiciones políticas, por ejemplo, y a las que perciben como erróneas:

Tiendo a crear post [sic.] muy críticos a la sociedad actual en mi país y sobre todo con las figuras de poder establecidas. Aunque también es prácticamente irresistible el hecho de contestar de buena o mala manera posturas erróneas o que deriven en pensamientos absurdos o sin criterio alguno (Usuario de sexo masculino, de 32 años).

El mismo informante aceptó abiertamente ejercer el troleo contra otros usuarios que presentan actitudes hostiles, en una especie de TrollingAnti-Trolling del que habla Phillips (2012) y que, Cole y West (2016) consideran aceptable dentro de una comunidad en línea: "Si previamente noté cierto carácter hostil, procuro ser más hostil inclusive y argumentar de mejor manera mis respuestas. Me gusta mucho trollear [sic.], pero también procuro hacerlo de una manera más efectiva".

\section{Retratos de un momento}

Con respecto a la configuración de los perfiles de los siete usuarios que protagonizan las 10 publicaciones analizadas, se encontraron los siguientes tipos: 


\section{Esquema 1. Tipos de identidad configurada por los emisores de las publicaciones de la muestra}
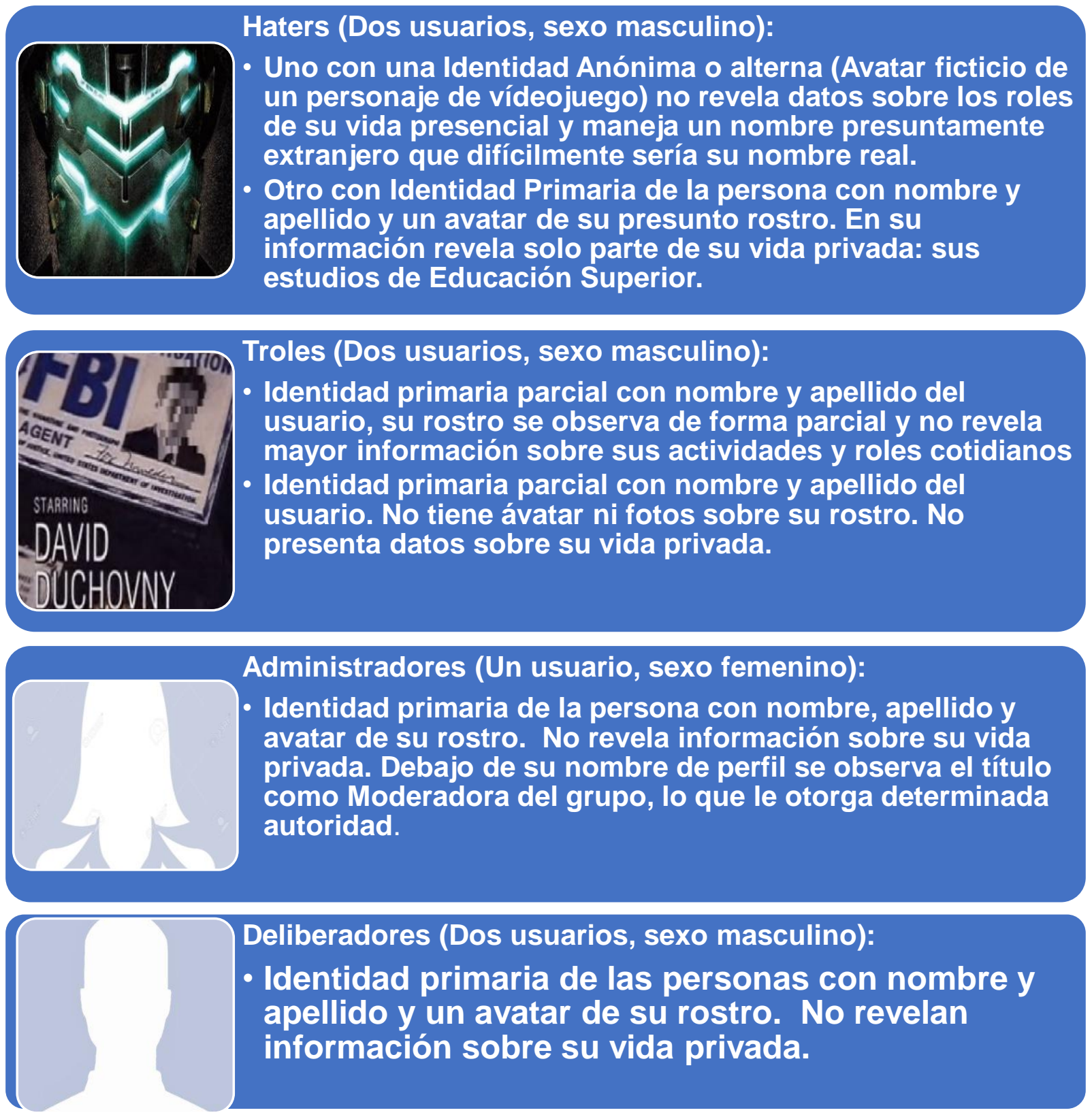

Fuente: elaboración propia

Los informantes aceptaron que los elementos de su perfil en Facebook son una proyección sobre lo que quieren que los demás vean de ellos, conforme a elementos como aficiones (fotos y portadas de personajes históricos), viajes, aventuras o estados emocionales. Quienes configuran una imagen anónima o alterna, dijeron hacerlo en el sentido de mostrar algún significado o cualidad. Así lo expresó una persona, al 
que se clasificó como hater, al hablar de su avatar: "Es la foto de un personaje de videojuegos que representa el adaptarse a condiciones adversas para su supervivencia. Resilencia en pocas palabras" (usuario de sexo masculino, de 39 años).

Igualmente, los entrevistados piensan que los comportamientos incorrectos en el grupo se deben a cuestiones que van del fanatismo y la ignorancia, a la búsqueda de atención o por politizar y provocar el debate. De acuerdo con el ranking de influencia de los usuarios del grupo Historia, según Gritycs, los integrantes con puntuaciones más altas — con más visibilidad - fueron de las tipologías Administradores (924 puntos), Haters (692 puntos) y Troles (650 puntos) ${ }^{23}$.

Por último, a pesar del número de integrantes del grupo Historia (14, 230 personas), durante el periodo de análisis, solo el 8.5 por ciento del total participó activamente con publicaciones o comentarios, lo que habla de una gran concentración de la participación en solo un grupo reducido de usuarios.

\section{Reflexiones finales}

Mediante la presente investigación se encontró que existen en el grupo Historia, de Facebook, personas que se valen de recursos incendiarios para apelar a la otredad. Ellos diseñan representaciones de sí mismos que retoman de códigos de comportamiento que circulan en el entorno digital, como el trolling o el hating, y los resignifican con base en elementos del contexto social en México.

A pesar de lo que dice la literatura al respecto, no todos los que ejercen el trolling o el hating lo hacen desde el anonimato y el engaño. Son prácticas de la comunicación en línea que adquieren significado en el momento en que se dan y en cruces de comportamientos en los que los internautas pueden cambiar de roles. Esto apunta a que todos podemos ser troles y haters en determinado momento, y por determinadas razones, para después dejar de serlo.

\footnotetext{
${ }^{23} \mathrm{El}$ algoritmo de Grytics mide la influencia del usuario al sumar el número de reacciones recibidas en sus publicaciones + el doble de número de comentarios que estas generan.
} 
Igualmente, se observó en los integrantes de la muestra que los contenidos incendiarios se tornan en vehículos de afectividades en red y les generan un sentido identitario a partir de reducciones dicotómicas de la realidad. Esto, conjugado con un bajo nivel de participación en los foros y configuraciones de privacidad cerrada, potencia la posibilidad de formar cámaras de eco en las que no se aceptan opiniones contrarias a la propia. No obstante, en el grupo observado es permitida la confrontación con contenidos diametralmente opuestos en el espectro político.

Las dinámicas de aparatos socio-tecno-culturales como Facebook están impulsando, bajo una lógica mercantil, los contenidos tóxicos. Bajo estas condiciones, la práctica del troleo retribuye a quien la ejerce un mayor grado de visibilidad, en un proceso de doble agencia tanto humana como no humana.

Lejos de clamar por la censura o la desconexión digital, se debe alertar sobre la necesidad de un uso responsable e informado de los medios sociales y sus posibilidades para el empoderamiento ciudadano. La reflexión final es que no solo el debate sino también el conflicto son más que necesarios en momentos difíciles en los que -ante los embates de los discursos hegemónicos de la dominación- es imprescindible no replegarse de los espacios públicos, tanto presenciales y digitales.

\section{Referencias}

Amaral, A., y Monteiro, C. (2013). Esses roquero não curte: performance de gosto e fãs de música no Unidos Contra o Rock do Facebook1/These rockers don't like: taste as performance and music fans at Facebook fanpage United Against Rock. Revista Famecos, 20(2), 446.

Bishop, J. (2013). The effect of de-individuation of the Internet Troller on Criminal Procedure implementation: An interview with a Hater. International Journal of Cyber Criminology, 7(1). 
Bucher, T. (2013). The friendship assemblage: Investigating programmed sociality on Facebook. Television \& New Media, 14(6), 479-493.

Buezas, T. C. (2012). Odio racial en la Internet. Cuadernos Americanos: Nueva Epoca, 1(139), 135-160.

Burroughs, B. (2013). FCJ-165 Obama Trolling: Memes, Salutes and an Agonistic Politics in the 2012 Presidential Election. The Fibreculture Journal.

Castells, M. (2008). Comunicación, poder. México, Siglo XXI.

Coles, B. y West, M. (2016). Trolling the trolls: Online forum user's constructions of the nature and properties of trolling. Computers in Human Behavior, 60, 233-244.

Couldry, N. (2004). Theorising media as practice. Social semiotics, 14(2), 115-132.

Cheney-Lippold, J. (2011). A new algorithmic identity: Soft biopolitics and the modulation of control. Theory, Culture \& Society, 28(6), 164-181

Dhalberg, L. (2001). Computer-mediated communication and the public sphere: A critical analysis. Journal of Computer-Mediated Communication 7.

(2007). The Internet and discursive exclusion: From deliberative to agonistic public sphere theory. Radical democracy and the internet: Interrogating theory and practice, pp. 128-147.

Dery, M. (1995). Flame wars: The discourse of cyberculture. USA, Duke University Press.

Donath, J. (1999). Identity and deception in the virtual community. Communities in cyberspace, 1996, 29-59.

Facebook (2019). Groups. Recuperado el 8 de marzo de 2019 de: https://newsroom.fb.com/products/

Fernández, I. (2015). Tuitéame una historia de villanos. Cuando la Historia y la tecnología se encuentran, o de cómo Carlota y Porfirio Díaz recurren hoy a Twitter para alcanzar la reivindicación social En XXII Anuario Coneicc, 109-138.

Goffman, E. (1997). La presentación de la persona en la vida cotidiana. Buenos Aires: Amorrortu editores.

Habermas, J.(1987). Teoría de la acción comunicativa (Vol. 2). Madrid: Taurus. 
Hardaker, C. (2010). Trolling in asynchronous computer-mediated communication: From user discussions to academic definitions. Journal of Politeness Research. Language, Behaviour, Culture, 6(2), 215-242.

INEGI (2019). Usuarios de Internet, según grupos de edad 20012017. Recuperado el 8 de marzo de 2019, de: https://www.inegi.org.mx/temas/ticshogares/default.html\#Ta bulados

Internet World Stats (2017). Facebook Suscriber Stats as of June 30, 2017. Recuperado el 30 de septiembre de 2017 de: http://www.internetworldstats.com/facebook.htm Iturralde (2016). "Ser o no ser". Los referentes temáticos en la configuración de identidad de un grupo de tuiteros de la ciudad de Querétaro. En Anuario de la Investigación en Comunicación México, Coneicc, 157-174.

Jamieson, K. H., y Cappella, J. N., (2008). Echo chamber: Rush Limbaugh and the conservative media establishment. Oxford University Press.

Jarrett, K. (2008). Interactivity is evil: A critical investigation of Web 2.0. First Monday, 13(3). Recuperado el 2 de febrero de 2017, de: http:/ / firstmonday.org/article/view/2140/1947

Karppi, T. (2013). FCJ-166 'Change name to No One. Like people's status' Facebook Trolling and Managing Online Personas. The Fibreculture Journal.

Kim, L. (2013). Denotation and connotation in public representation: semantic network analysis of Hwang supporters' internet dialogues. Public understanding of science, 22(3), 335-350.

Knobel, M., y Lankshear, C. (2007). Online memes, affinities, and cultural production. A new literacies sampler, 29, 199-227.

Latour, B. (2007). Reensamblar lo social. Manantial, Buenos Aires.

MacKinnon, R., \& Zuckerman, E. (2012). Don't feed the trolls. Index on Censorship, 41(4), 14-24.

Markey, L. (2013). Starving the trolls: How the news media and harassament victims can fight harmful speech online. USA: University of Kansas.

McCosker, A (2014). Trolling as provocation YouTube's agonistic publics. Convergence: The International Journal of Research into New Media Technologies, 20(2), 201-217. 
Milner, R. M. (2013). FCJ-156 Hacking the Social: Internet Memes, Identity Antagonism, and the Logic of Lulz. The Fibreculture Journal, (22 2013: Trolls and The Negative Space of the Internet).

Montesinos, A. B. (2007). Estrategias de revisionismo histórico y pedagogía del odio. Anuario de Pedagogía, (9), 47-102.

Mouffe, C. (2000). Deliberative democracy or agonistic pluralism. Recuperado el 5 de febrero de 2018, de:

https://www.ssoar.info/ssoar/bitstream/handle/document/24 654/ ssoar $\%$ E2\%80\%902000\%E2\%80\%90mouffe $\%$ E2\%80\%9 Odeliberative_democracy_or_agonistic_pluralism.pdf?sequence $=1$

Papacharissi, Z. (Ed.). (2010). A networked self: Identity, community, and culture on social network sites. Nueva York: Routledge. (2015). Affective publics: Sentiment, technology, and politics. Oxford: Oxford University Press.

Pérez, Gervasi, F., y Cuevas, B. (2014). Santa flaquita, líbranos de los trolls. El sentido de pertenencia en expresiones identitarias en torno al culto a la Santa Muerte en Facebook. Religioni e società, (79), 84-104.

Pérez, G., y Hernández, R. (2017) Expresiones de racismo y discriminación en grupos autistas en Facebook. Comparative Cultural Studies: European and Latin American Perspectives, 21-33.

Pérez, Bravo y Del Bosque (2018). Ocho de cada diez gatos prefieren el Komander: Una aproximación a expresiones de discriminación cultural en memes en redes sociodigitales. En Crovi, D. (Coord) Prácticas comunicativas en entornos digitales, pp. 113-130, México: UNAM.

Postill, J. y Pink, S. (2012). Social media ethnography: The digital researcher in a messy web. Media International Australia, 145(1), 123-134.

Rafferty, R. S. (2011). Motvations Behind Cyber Bullying and Online Aggression: Cyber Sanctions, Dominance, and Trolling Online (Doctoral dissertation, Ohio University).

Reagle, J.M. (2015). Reading the comments: Likers, haters, and manipulators at the bottom of the Web. Cambridge, MA: MIT Press. 
Serrano-Puche, J. (2012) La presentación de la persona en las redes sociales. Análisi, 46, 1-17.

Shepherd, T., Harvey, A., Jordan, T., Srauy, S., y Militner, K. (2015). Historias de odio. Social Media + Society , 1 (2).

Sibilia, P. (2012). La intimidad como espectáculo. Fondo de Cultura Económica.

Silver, J. (productor), Wahowski, L., y Wachoski, L. (directores). (1999) The Matrix (cinta cinematográfica). E.U. Village Roadshow Pictures \& Silver Pictures.

Stein, J. (2016, 18 de Agosto). How Trolls are ruining the Internet [version electronica]. Time. Recuperado el 1 de septiembre de 2016, de: http:/ / time.com/4457110/internettrolls/?xid=fbshare

Taylor, A. (2014). The People's Platform: Taking Back Power and Culture in the Digital Age. Random House Canada.

Tepper, Michele. (1997) Usenet communities and the cultural politics of information. In David Porter (ed.), Internet culture, 3954. New York: Routledge.

Vaidhyanathan, S. (2018). Antisocial media: How Facebook disconnects us and undermines democracy. Oxford: Oxford University Press.

Trejo, R. (2014). Somos constelaciones. medios tradicionales y redes sociales en la construcción de la identidad. Revista

Latinoamericana de Ciencias de la Comunicación, 9(17).

Van Dijck, J. (2013). 'You have one identity': performing the self on Facebook and LinkedIn. Media, Culture \& Society, 35(2), 199-215.

We are social (2017). Digital 2019. Recuperado el 8 de marzo de 2019, de: https://wearesocial.com/blog/2019/01/digital-2019_ global-internet-use-accelerates

Yus, F. (2010). Ciberpragmática. Ariel, España.

Herramientas metodológicas:

e-encuestas.com

Gephi 0, 9, 2.

Grytics.com 


\title{
Jóvenes mexicanos en contexto digital: prácticas online que llevan a riesgos
}

\author{
Sergio Rivera Magos \\ Universidad Autónoma de Querétaro (México) \\ riveramagos2013@gmail.com ${ }^{24}$ \\ Bruno Carriço Reis \\ Universidade Autónoma de Lisboa (Portugal) \\ reysbr@gmail.com ${ }^{25}$
}

\begin{abstract}
PARA CITAR: Rivera Magos, S. \& Carriço Reis, B. (2019). "Jóvenes mexicanos en contexto digital: prácticas online que llevan a riesgos”. En Barredo Ibáñez, D.; Rodrigues da Cunha, M. \& Hidalgo Toledo, J. (Eds.) (2019). Jóvenes, participación y medios de comunicación digitales en América Latina <pp. 133-161>. La Laguna, España: Cuadernos Artesanos de Comunicación. DOI: 10.4185/cac156
\end{abstract}

\section{Resumen}

El presente capítulo tiene como objetivo identificar el consumo, actitudes, y conjunto de prácticas digitales de los jóvenes estudiantes de preparatoria en el Municipio de Querétaro, México; además, detectar los posibles riesgos derivados de su actividad en Internet. El estudio, de tipo cuantitativo, basa su metodología en una encuesta aplicada a 600 jóvenes estudiantes de 12 preparatorias del municipio mencionado. La investigación demuestra que las prácticas digitales de

${ }^{24}$ Investigador del Núcleo de Investigação em Práticas \& Competências Mediáticas (NIP@COM/UAL).

${ }_{25}$ Coordinador/Investigador del Núcleo de Investigação em Práticas \& Competências Mediáticas (NIP@COM/UAL). Investigador del NEAMP (PUCSP) y del OBSERVARE (UAL). 
los jóvenes estudiados implican conductas de riesgo y los colocan en situaciones de inseguridad. Concluye, además, que las prácticas intensivas online de los jóvenes estudiantes configuran una normalización del riesgo. Este trabajo evidencia la necesidad de crear políticas públicas para concientizar a los jóvenes acerca de los riesgos inherentes a su actividad en Internet.

\section{Palabras clave}

Prácticas digitales, Riesgos, Jóvenes, Internet, Redes sociodigitales.

\section{Introducción}

$\mathrm{E}$ L USO de Internet, por parte de los jóvenes, genera prácticas que pueden eventualmente derivar en riesgos. En México, la situación demanda un pronto análisis en búsqueda de soluciones y medidas de prevención. Según el Índice de Civilidad Digital (DCI), elaborado por Microsoft, México se encuentra en el penúltimo lugar, como uno de los países más expuestos a los riesgos en Internet.

De acuerdo al índice mencionado, ocho de cada diez adultos encuestados declararon haber estado relacionados con temas de intrusión a la privacidad y de naturaleza sexual. Según el DCI, el 54\% de las personas encuestadas reportaron haber sido contactadas sin su conocimiento a través de Internet, 39\% recibieron sexting, sin solicitarlo, y el 25\% fueron objeto de propuestas sexuales a través de la red.

Dada esta situación, el presente estudio parte de la pregunta acerca de ¿las prácticas digitales de los jóvenes queretanos conllevan comportamientos de riesgo, y de ser así, de qué tipo? A partir de esta pregunta, se pretende identificar el consumo, actitudes, y conjunto de prácticas digitales de los jóvenes de la muestra, además, detectar los posibles riesgos derivados de su actividad en Internet.

El presente capítulo brinda antecedentes acerca del consumo de Internet en México y un sucinto estado de la cuestión sobre la investigación de prácticas digitales juveniles, y el campo de estudio 
sobre riesgos que los jóvenes corren en Internet. Se reflexiona sobre el uso que los jóvenes hacen de las Tecnologías de la Información y la Comunicación (TIC), en especial su relación con las redes sociales digitales. Se revisan además los riesgos inherentes a estar en la red y su tipología, entendiendo a los jóvenes como un grupo poblacional especialmente vulnerable.

A partir de la pespectiva teórica, enunciamos el diseño metodológico y sus particularidades, para así presentar los resultados empíricos obtenidos y su consecuente análisis, discusión y conclusiones finales.

\section{El entorno digital en México}

El uso de Internet en México ha crecido espectacularmente en los últimos años. Según cifras del Instituto Nacional de Geografía y estadística (INEGI, 2018), actualmente usan Internet en México 79.1 millones de personas. El incremento respecto a las cifras del 2016 es hasta de $12 \%$, alcanzando un nivel de penetración del $67 \%$, siendo los jóvenes, entre 12 y 24 años de edad, quienes con un 35\% ocupan el mayor porcentaje del total de usuarios (Asociación de Internet.mx, 2018). En lo que respecta al consumo de Internet en Querétaro, hay actualmente 436,016 jóvenes entre 12 y 24 años de edad usuarios de la red (INEGI, 2018).

Esto quiere decir que el uso de Internet se extiende cada vez más entre los jóvenes mexicanos, siendo su consumo un aspecto habitual de su vida cotidiana. Aunque el acceso a Internet es más alto entre los universitarios, cuatro de cada cinco estudiantes de nivel preparatoria utilizan habitualmente Internet.

El dispositivo principal de conexión del internauta mexicano es el smatphone $(76 \%)$, y la actividad dominante es el acceso a redes sociales digitales (89\%), siendo Facebook la más utilizada, por un $98 \%$ de los usuarios de Internet. El consumo de WhatsApp se ha disparado en México, es la segunda red sociodigital más consumida por los internautas (91\%) (Asociación de Internet.mx, 2018). 
Cabe destacar que, si bien Facebook es la red social más usada, convive con una variedad de ellas, pues los usuarios mexicanos tienen en promedio cinco redes sociodigitales, y sólo el 1\% de los internautas no cuenta con ninguna. En cuanto al tiempo de conexión se hace hincapié ue el 64\% de los usuarios percibe que está conectado a Internet las 24 horas del día (Asociación de Internet.mx, 2018).

Internet forma parte de la realidad cotidiana de los mexicanos, cada vez son más los que están conectados y navegando por alguna red sociodigital, si bien es cierto existen diferentes brechas y un sector importante de la población desconectado, la tendencia de crecimiento indica que seguirá aumentado su uso, siendo los jóvenes los usuarios principales del servicio.

\section{El estudio de los comportamientos digitales juveniles en México}

La elaboración de un necesario estado del arte sobre el estudio de prácticas digitales juveniles, y riesgos de los jóvenes en Internet en México, nos permite hacer una descripción sucinta del estado de la investigación sobre el tema, más que hacer un listado de trabajos, se pretende dar un panorama de lo observado.

Lo primero que se hizo evidente en la revisión es que la categoría jóvenes ha generado trabajos principalmente sobre estudiantes, ya sea de nivel medio o universitario, siendo este último el que consigue la mayor atención por parte de los investigadores. Esta tendencia pudiera explicarse a partir de que los universitarios son una población más accesible para los investigadores y ofrecen muestras derivadas de grupos o niveles escolares de instituciones académicas de más directo acceso para el investigador. Este patrón ha generado estudios referenciales sobre universitarios como el de Delia Crovi (2009).

La primacía de los universitarios como objeto de estudio plantea la necesidad de analizar otros grupos juveniles, como el de los estudiantes de preparatoria, cuyo consumo e interés por las TIC reclama estudios enfocados a ellos, especialmente a los de la provincia mexicana. Esto cobra relevancia si observamos otra tendencia visible referida a que los estudios sobre jóvenes y TIC, en su mayor parte, se llevan a cabo en la 
Ciudad de México. Investigaciones de carácter nacional, como las dirigidas por la propia Crovi (2016), que pretende revisar el uso de redes sociales de estudiantes en diferentes universidades mexicanas, tanto de la Ciudad de México, como de otras entidades federativas, contribuyen a disminuir este sesgo.

El centralismo en la investigación no sólo ocurre en la elección de los centros educativos y muestras usadas, también en los grupos de investigación y universidades que se ocupan de lo digital-juvenil. Las universidades que mayor número de estudios generan son la Universidad Nacional Autónoma de México (UNAM) y la Universidad Autónoma Metropolitana (UAM), que cuentan con cuerpos académicos y equipos de investigación que permiten proyectos de investigación de mayor envergadura. En provincia las investigaciones surgen de profesionales solitarios o de grupos de académicos que trabajan temas afines (Domínguez y López, 2015).

Actualmente comienza a haber estudios que intentan conocer acerca de jóvenes y TIC en entornos rurales como el de Morales, Lavigne y Mercado (2016), que indaga sobre las apropiaciones de la TIC de parte de estudiantes rurales de una universidad virtual. El estudio, entre otras conclusiones, demuestra un acceso desigual a las TIC entre estudiantes urbanos y rurales, estando estos últimos en desventaja en cuanto a condiciones para su apropiación. Este tipo de estudios deja ver la necesidad de mirar más allá de las ciudades y áreas metropolitanas para poner atención a lo que sucede con los estudiantes no urbanos en el contexto de las nuevas ruralidades, identificando más que brechas, desigualdades.

El interés de los jóvenes por el uso de las redes sociodigitales promueve una gran cantidad de estudios en torno a diferentes aspectos relacionados con apropiaciones juveniles de Facebook principalmente, y de otras redes digitales que han ido incorporándose a la ecología de medios en la que los jóvenes se desenvuelven. Las preguntas propuestas por los investigadores, como lo señalan Domínguez y López (2015), pretenden conocer los usos escolares, el tipo de contenidos o temas consumidos y las herramientas tecnológicas usadas para el acceso y uso de las mismas. 
En cuanto al estudio sobre riesgos o consecuencias negativas del uso de Internet por parte de los jóvenes, podemos mencionar que la mayoría de los trabajos están enfocados a muestras de adolescentes, como sujetos vulnerables o víctimas potenciales (Ortíz, 2012). La mayoría de estos trabajos proceden del ámbito de la psicología o pedagogía, áreas dominantes en el análisis de comportamientos de riesgo en la red.

Existen una variedad de esfuerzos que tratan de explicar el impacto de Internet sobre los hábitos de lectura (Domínguez y Pérez, 2015), el bajo aprovechamiento escolar (Castellana, Sánchez, Graner y Beranuy, 2007), sobre la adicción o el uso excesivo de esta plataforma (Ortíz, 2012). Recientemente, la privacidad en jóvenes estudiantes ha generado trabajos al respecto, que revisan prácticas en torno a la gestión de la privacidad en la red (Sepúlveda, 2017). Sobre el factor de riesgo en redes sociales concretamente Pacheco, Lozano, y González, (2018) realizaron un estudio con adolescentes en Zacatecas, donde detectan conductas de riesgo asociadas al sexting y grooming, entre otras amenazas.

Podemos obsevar que existe una necesidad de investigación por atender, respecto a cómo las prácticas digitales de los jóvenes de preparatoria pueden conllevar riesgos, los adolescentes en este sentido han acaparado la atención, sobre todo de estudios provenientes de la psicología, bajo la noción de que estos riesgos no son tan críticos o importantes en otras etapas o periodos de la vida juvenil.

\section{La formacion de las culturas juveniles en las redes sociodigitales}

Los jóvenes han conferido un papel central a las TIC, considerando a Internet como un medio "amigo", un aliado para gestionar sus necesidades de comunicación y entretenimiento. Bajo esta lógica, los jóvenes se apropian de los medios desarrollando modos de empleo significativos (Tully, 2007). Estas prácticas juveniles son conscientes y pretenden la autorregulación y la independencia del arbitraje adulto, dando lugar a un uso de naturaleza lúdica/utilitaria, cargada de un importante contenido simbólico (Rubio, 2010). 
Las prácticas digitales juveniles más significativas tienen lugar en las redes sociodigitales, espacio para la sociabilidad y comunicación entre pares (Crovi, 2016). Es por ello que su estudio se ha convertido en una de las preocupaciones de todas aquellas disciplinas interesadas en la cultura digital. El término redes sociales cobra sentido para la comunicación a partir de las redes digitales, sin embargo, para las ciencias sociales este concepto ya implicaba un planteamiento teórico y una propuesta metodológica para su estudio.

Como sujetos, estamos inmersos en un entramado de redes analógicas previas a las redes sociales digitales. Una red social "se integra de una red micro-social que inicia con la familia y se extiende a todo el entorno sociocultural en el que nos desenvolvemos hasta enlazarse a toda una red social a la que moldeamos y que nos moldea" (Sluzki, 1996 en Crovi, 2009, p. 229). Pertenecemos entonces a redes sociales por el hecho mismo de formar parte de una colectividad desde que nacemos contamos con una comunidad de soporte que nos es natural (Bauman, 2016).

Moviendonos en redes que nos son naturales, ampliamos nuestra vida social a través de lo digital, bajo esta lógica, las redes sociodigitales pueden "ser entendidas como el conjunto de interacciones de esta red física, histórica en toda sociedad y en la biografía de los sujetos, que ahora se desarrollan en una plataforma digitalizada, un nuevo espacio social que permite interacciones virtuales" (Crovi, 2016).

Los jóvenes usuarios de Internet utilizan las redes sociodigitales para diferentes fines, pero desde su aparición se ha visto que la comunicación digital favorece la conversación y la socialización (Pereira, Spitzberg y Matos, 2016; Watts, 2007), para los jóvenes son herramientas que los acercan a sus pares, pues ellos sienten que pertenecen a un grupo afín (Serapio, 2006).

Los jóvenes utilizan las redes sociodigitales para expandir o enriquecer su vida social offline, interactuando tanto en el espacio físico, como en el ciberespacio, sin hacer las pretendidas diferencias entre lo real y lo virtual; los espacios digitales de acuerdo con Winocur, representan "estrategias de reforzamiento y de recreación de los vínculos y círculos 
sociales tradicionales en los que está inmersa la población juvenil. En este sentido, "los jóvenes se mueven en dos mundos de experiencia diferentes, pero que no son vividos como antagónicos, sino como continuos, convergentes, y complementarios" (Winocur, 2006, p.578).

A pesar de que se asume que los jóvenes están huyendo de Facebook en búsqueda de otras redes libres de la injerencia de padres y otros adultos, la red más usada en México es precisamente esta plataforma, lo que confirma su hegemonía y la falta de sustento acerca de su abandono por parte de los jóvenes (Grove, 2013; ComScore, 2016). La tendencia entonces parece apuntar al uso de Facebook como una red sociodigital de uso extendido entre los jóvenes que va acompañada de otras redes digitales orientadas a la fotografía como Instagram, e incluso aquellas de contenido efímero como Snapchat.

Se presume apriori -desde la noción de prosumidor- que los jóvenes utilizan también las redes sociodigitales para producción de contenidos, este supuesto tampoco se sostiene desde la evidencia empírica (Crovi, 2016; Dans, 2016). El uso se remite entonces a las funciones básicas de comunicación y socialización de las plataformas, un uso práctico simplificado que no muestra intención de producir contenidos ejerciendo el potencial de prosumo atribuido a las redes sociodigitales.

Para los jóvenes preparatorianos, las redes son un espacio para el entretenimiento y la comunicación (Crovi, 2016; INEGI, 2017). Un lugar para gestionar su imagen digital y la relación con amigos y conocidos, de acuerdo a Winocur, interviene en la "construcción y reconstrucción de las identidades juveniles en las grandes ciudades" (p.576), desde ellas el joven se muestra, utilizando los recursos digitales que estas ofrecen.

Las prácticas digitales de naturaleza diversa no están exentas de situaciones conflictivas o de riesgo, el uso intensivo y la valoración de Internet como un lugar natural para la satisfacción de necesidades de los jóvenes no necesariamente incluye una actitud alerta y conocimiento de los riegos inherentes a estar en la red. 


\section{Los riesgos de los jóvenes en la red}

Las prácticas juveniles en la red, están marcadas por la intensidad y la movilidad, pero también por riesgos potenciales inherentes al ciberespacio. Las redes sociales digitales difuminan las fronteras de la intimidad y lo público, poniendo en riesgo a los usuarios no consientes de los peligros a los que se exponen. Los jóvenes privilegian el acceso sobre los controles de seguridad y privacidad, lo importante para ellos es estar en las redes, bajo la lógica de que el que no está en ellas "no existe" (Del Barrio y Fernández, 2016, p. 573).

El uso seguro de redes sociodigitales implica alfabetización y el implemento de precauciones y medidas antiriesgo (Tarín y Navarro, 2006). Es por ello necesario que los jóvenes adquieran competencias digitales que los mantengan a salvo de las amenazas en la red (Del Barrio y Fernández, 2016). Es importante conocer los riegos propios de internet y su variedad a fin de tener conciencia de los mismos y de sus posibles consecuencias.

De acuerdo a la Organización Mundial de la Salud (2013) un factor de riesgo es aquel que incrementa la posibilidad de que un individuo sufra una lesión o enfermedad. Los riesgos se incrementan cuando el individuo incurre en conductas de riesgo, que pueden ser voluntarias o involuntarias, activas o pasivas; las que le pueden traer consecuencias nocivas para su salud, integridad o seguridad (Fonseca, 2010 en Rosabal, Muñoz, Ramírez y Hernández, 2015).

Los riesgos vistos como categoría vinculada al desarrollo tecnológico y los medios, implican dos dimensiones (Marciales y Cabra, 2011). La primera se refiere a la acción histórica de la tecnología como generadora de riesgos en la sociedad (Hansson ,2002). La segunda, a que el advenimiento de nuevos medios ha producido riesgos relacionados con la inseguridad y el pánico moral, que Cohen (1972) define como personas o grupos que constituyen una amenaza a los valores e intereses de la sociedad, teniendo como particularidad el que generalmente reciben atención mediática. 
Los riesgos están presentes en las prácticas de consumo digital de los jóvenes. Como afirman Alonso, Rodríguez y Pérez (2015) "es precisamente en este marco de virtualidad, caracterizado por el uso de la telefonía móvil, la mensajería instantánea o las redes sociales en donde surgen nuevas prácticas de riesgo virtual y real" (p.58). A partir de la llegada de Internet, como tecnología transversal en la vida cotidiana, la aparición de riesgos derivados de lo digital ha sido constante y creciente.

La literatura especializada consigna diferentes riesgos que son considerados como una amenaza a la seguridad y la privacidad de niños y adolescentes; sin embargo, la atención decrece en poblaciones juveniles más adultas como la de los estudiantes de enseñanza media superior que en este estudio nos ocupa. Los principales riesgos que corren los jóvenes en Internet según Espinar y López (2009), pueden resumirse en: abuso o adicción, vulneración de derechos industriales o de autor, acceso a contenidos inapropiados, interacción o acecho por parte de otras personas, acoso sexual, amenazas a la privacidad, riesgo económico y/o fraude, riesgos técnicos (virus, troyanos, malware).

Existen riesgos particularmente alarmantes, pues lastiman la dignidad y estabilidad emocional de los jóvenes. Tal es el caso del cyberbullying, que Marciales y Cabra (2011) definen como "todo comportamiento dirigido y repetido para infligir daño, bien sea a través del teléfono móvil, el correo electrónico o los mensajes instantáneos, o la difamación a través de la web” (p. 857). El bullying, ya presente en los entornos escolares en todos los niveles, se ha potenciado por la disponibilidad de las redes sociodigitales como canal y herramienta para el acoso online. En este sentido, la investigación sobre cyberbullying resulta urgente, como una instancia previa a estrategias de intervención en los planteles escolares y como vía de concientización de padres y jóvenes en general.

Un grupo de riesgos que amenaza a los jóvenes en la red es el relacionado con lo sexual. Una variedad de situaciones pone permanentemente en peligro a usuarios de la red no alfabetizados en cuanto a su uso seguro y responsable. Marciales y Cabra (2011), nos proveen de un listado que revela distintos tipos de riesgo en la red, los 
principales son: demandas sexuales no deseadas, acoso, y exposición indeseada a la pornografía.

Como hemos visto los riegos relacionados con el sexo son críticos y variados, como lo es la categoría que aglutina diferentes riesgos es la denominada "uso problemático de Internet" (Malini, Osuldella y Blasio, 2009). Esta categoría hace referencia al uso indiscriminado e intensivo de internet, sin importar el día o semana, afectando la interacción de los sujetos en la vida cotidiana (Marciales y Cabra, 2011).

También es importante señalar que una correlación fuertemente abordada por investigadores del tema es la que se presenta entre el tiempo que los niños dedican a internet, y su aprovechamiento escolar (Jackson et al., 2008; Levine, Waite y Bowman, 2007).

Como podemos ver, navegar en la red no resulta inocuo, pues existen amenazas y mal uso de la misma por parte de quien aprovecha el anonimato o la posibilidad de falsear identidad o intenciones. Pretendemos desde los datos aportados por los mismos jóvenes, entender de manera empírica los riesgos a los que están expuestos.

\section{Metodología}

El presente estudio es de tipo exploratorio y de enfoque cuantitativo extensivo $^{26}$. La muestra utilizada está constituida por 600 jóvenes estudiantes (318 mujeres y 282 hombres) de enseñanza media superior -también conocida como preparatoria o bachillerato- del Municipio de Santiago de Querétaro. Este municipio es la capital del Estado de Querétaro y cuenta con 101 preparatorias con un total de 28 mil 654 estudiantes (SEP, 2016). A partir de este universo se buscó obtener una

\footnotetext{
${ }^{26}$ Este trabajo replica el diseño de una investigación previa desarrollada por el Núcleo de investigação em práticas e competências mediáticas (NIP-C@M) de la Universidad Autónoma de Lisboa. El estudio original, coordinado por la Doctora Paula Lopes, presentó sus resultados en el siguiente informe; Lopes, P.; Reis, B.; Quintas, C. y Amaral, I. (2015). Direitos digitais: Uma password para o futuro. Relatório do Inquérito UAL/DECO 2014-2015. Lisboa: UAL. Consultado el 30 de marzo de 2018 en http://repositorio.ual.pt/bitstream/11144/1865/1/DIREITOS\%20DIGITAI $\underline{S \text { relatorio final.pdf }}$
} 
muestra que, aunque no fuera representativa de las principales variables sociodemográficas del grupo analizado, sí estuviera calculada de acuerdo con el tamaño del universo en cuestión ${ }^{27}$.

La presente investigación empírica se basó en la aplicación de una amplia encuesta integrada por 28 preguntas $^{28}$, a estudiantes del nivel educativo medio-superior con una media de edad de 17 años. Se optó por la aplicación de una encuesta en doce preparatorias ${ }^{29}$-elegidas por tener más de 500 alumnos- pertenecientes al Municipio de Santiago de Querétaro. Se decidió aplicar cincuenta cuestionarios por escuela, divididos entre los seis semestres correspondientes al ciclo de enseñanza media superior. Se realizaron encuestas en los turnos matutino y vespertino en aquellas escuelas que contaban con ambas modalidades. La encuesta fue aplicada por un equipo de asistentes de investigación que acudieron a los planteles con la correspondiente autorización de sus directivos ${ }^{30}$.

${ }^{27}$ Con este objetivo se utilizó el programa STATS, al que se alimentó además del universo mencionado, con un margen de error de $5 \%$, un porcentaje estimado de la muestra del 50\%, y un nivel deseado de confianza del $95 \%$. ${ }^{28}$ Las preguntas que conformaron el cuestionario estuvieron agrupadas en los siguientes bloques temáticos: 1) Prácticas digitales (frecuencias de uso, horas de navegación por día, dispositivos utilizados para conectarse a Internet, tipo de red, actividades online, frecuencia de las actividades online, y descargas); 2) Redes Sociales (perfil, tipo de perfil, información compartida y privacidad) y 3) Riesgos y vulnerabilidades en el mundo digital (ligar online, situaciones vividas y responsabilidad).

${ }^{29}$ Las escuelas que conformaron la muestra fueron: Escuela de Bachilleres Salvador Allende plantel norte (también conocida como Prepa Norte) y Escuela de Bachilleres Salvador Allende plantel sur (Prepa Sur), Colegio de Bachilleres del Estado de Querétaro plantel no. 1 (COBAQ plantel núm. 1 Satélite), COBAQ plantel núm. 8 Azteca, COBAQ plantel núm. 13 Epigmenio González, COBAQ plantel núm. 17 Constitución de 1917, COBAQ plantel núm. 22 Real de San Miguel, Centro de Estudios Tecnológicos Industrial y de Servicios núm. 16 (CETIS16), Colegio de Estudios Científicos y Tecnológicos plantel Querétaro (CECYTEQ, Querétaro), LICEO Corregidora, Prepa Contemporánea y el Colegio Preparatoria UNEA, en el municipio de Santiago de Querétaro; en los años escolares de 2015/2016 y 2016/2017.

${ }^{30}$ Los encuestadores recibieron previamente un taller donde se les capacitó sobre el contenido del cuestionario, su forma de aplicación y su presentación en la institución educativa. 
La encuesta es de carácter cuantitativo, lo que brinda posibilidades interpretativas que permiten la caracterización de las prácticas digitales juveniles, hábitos de uso en redes sociales, así como riesgos y vulnerabilidades implicadas desde sus autopercepciones. Del conjunto de elementos podemos configurar un determinado perfil de los usuarios encuestados.

\section{Trazando perfiles de la actividad online}

La gráfica 1 permite observar que de los 600 jóvenes que fueron encuestados, el $86.2 \%$ hace uso de internet todos los días. De forma complementaria observamos que el $1 \%$ de la muestra no usa Internet, mientras que un 10\% de ellos tienen hábitos de navegación parciales, de una a dos veces por semana. La primera lectura de estos datos nos indica que el cotidiano juvenil está atravesado por el uso intensivo de recursos digitales.

\section{Gráfica 1. Frecuencia de usos de Internet}

\section{¿Con qué frecuencia usas Internet?}

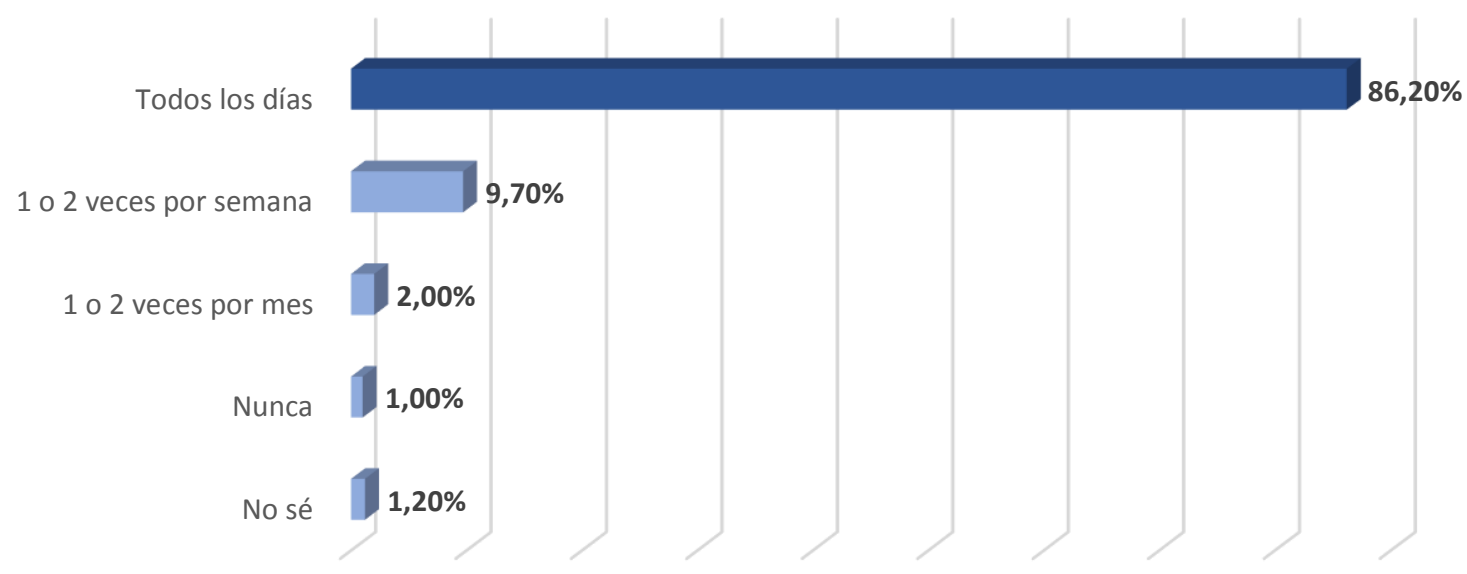

Fuente: elaboración propia

Desde su autopercepción registramos como evidencia más significativa que el 53.5\% de los casos desarrolla sus prácticas digitales en un lapso temporal comprendido entre 3 y 5 horas diarias (ver cuadro 1) 


\section{Cuadro 1. ¿Cuántas horas por día navegas en Internet?}

\begin{tabular}{|c|c|c|}
\hline $\begin{array}{l}\text { Horas de navegación } \\
\text { por día }\end{array}$ & No. Jóvenes usuarios & Porcentaje \\
\hline $1 \mathrm{hr}$ & 36 & $6.0 \%$ \\
\hline $2 \mathrm{hrs}$ & 75 & $12.5 \%$ \\
\hline $3 \mathrm{hrs}$ & 122 & $20.3 \%$ \\
\hline $4 \mathrm{hrs}$ & 109 & $18.2 \%$ \\
\hline 5 hrs & 90 & $15.0 \%$ \\
\hline $6 \mathrm{hrs}$ & 43 & $7.2 \%$ \\
\hline $7 \mathrm{hrs}$ & 12 & $2.0 \%$ \\
\hline $8 \mathrm{hrs}$ & 36 & $6.0 \%$ \\
\hline $9 \mathrm{hrs}$ & 12 & $2.0 \%$ \\
\hline $10 \mathrm{hrs}$ & 26 & $4.3 \%$ \\
\hline $11 \mathrm{hrs}$ & 4 & $0.7 \%$ \\
\hline $12 \mathrm{hrs}$ & 18 & $3.0 \%$ \\
\hline 13 hrs & 2 & $0.3 \%$ \\
\hline $14 \mathrm{hrs}$ & 1 & $0.2 \%$ \\
\hline $15 \mathrm{hrs}$ & 7 & $1.2 \%$ \\
\hline $16 \mathrm{hrs}$ & 2 & $0.3 \%$ \\
\hline $18 \mathrm{hrs}$ & 2 & $0.3 \%$ \\
\hline $20 \mathrm{hrs}$ & 1 & $0.2 \%$ \\
\hline $24 \mathrm{hrs}$ & 2 & $0.3 \%$ \\
\hline Total & 600 & $100 \%$ \\
\hline
\end{tabular}

Fuente: elaboración propia

Usos centrados en los teléfonos celulares (44\%) y/o su computadora/laptop personal (37\%) como se pone de manifiesto en la gráfica 2. Registramos que los dispositivos que permiten portabilidad como tecnología de conexión a Internet son los que recogen las preferencias de los usuarios juveniles. El conjunto de datos analizados hasta hora podría llevarnos a definir un perfil de utilización juvenil con marcas de omnipresencia tecnológica, con presencia continua en todos los contextos cotidianos de tránsito juvenil, pero tal deducción se puede aplicar a un tercio de los encuestados (gráfica 3).

Los jóvenes, en su mayoría, se conectan habitualmente a través de la red doméstica (84\%) y de forma secundaria desde datos móviles (33\%). 
Podemos ver que, aunque el gadget preferido de los jóvenes para conectarse a Internet es el teléfono celular, su principal conexión no es desde un plan de uso de Internet móvil pagado, sino desde la conexión doméstica. Lo que indica que el sentido de portabilidad no confiere por defecto una posibilidad de presencia y consumos online, ya que existe un número significativo de jóvenes que se conecta en su casa (84\%) y/o en plazas públicas (un 15\%).

\section{Gráfica 2. Dispositivo(s) que los jóvenes usuarios utilizan para conectarte a Internet}

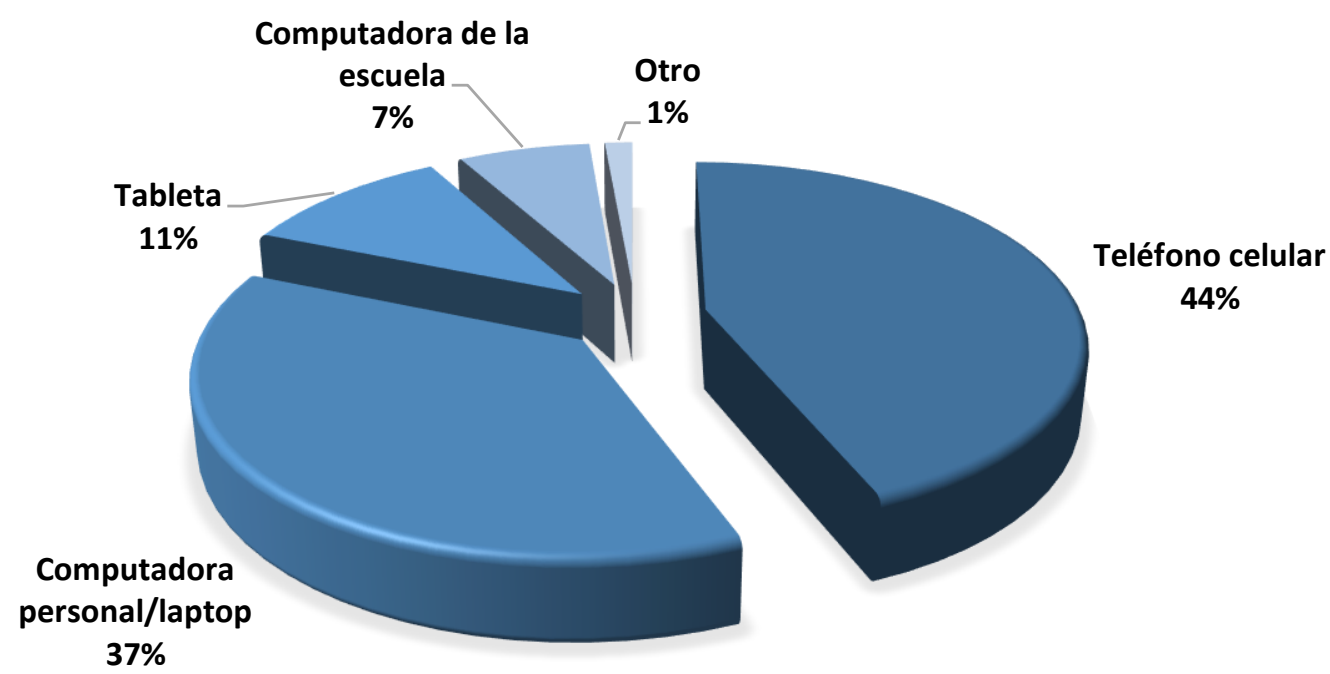

Fuente: elaboración propia

La idea subyacente que puede dar sentido a estos datos es que existe una cuestión de naturaleza económica que establece una barrera para la contratación de planes comerciales que permitan acceso a datos móviles. 


\section{Gráfica 3. Tipo de red a la que se conectan habitualmente}

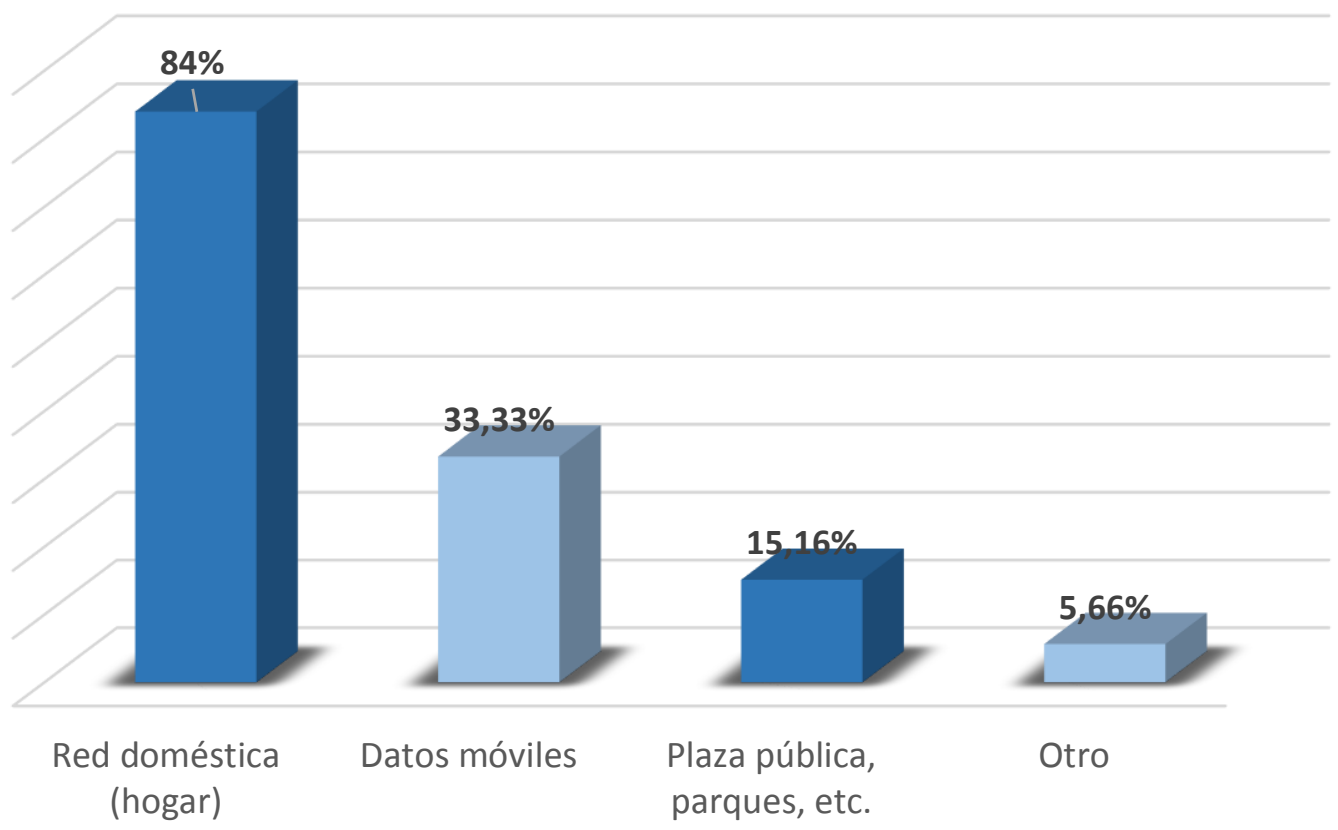

Fuente: elaboración propia

Considerando las formas de acceso interesa percibir qué hacen estos jóvenes online. $\mathrm{Al}$ interpretar los datos de la gráfica 4 podemos ver que utilizan sus dispositivos para: oír música en línea (43.16\%), participar en redes sociales $(38.33 \%)$, ver vídeos/series/películas en línea $(30.16 \%)$, participar en chats $(29 \%)$. Subrayamos un uso de internet con práctica de carácter eminentemente lúdica y las frecuencias expresivas en cuanto a mantener interacciones comunicativas mediadas por aplicaciones digitales. Solamente para casi un cuarto de los jóvenes, Internet sirve como herramienta de estudio (24\%), práctica que contrasta con la prevalencia del uso de Internet para el entretenimiento y la socialización. 


\section{Gráfica 4. Actividades favoritas en Internet de los jóvenes usuarios}

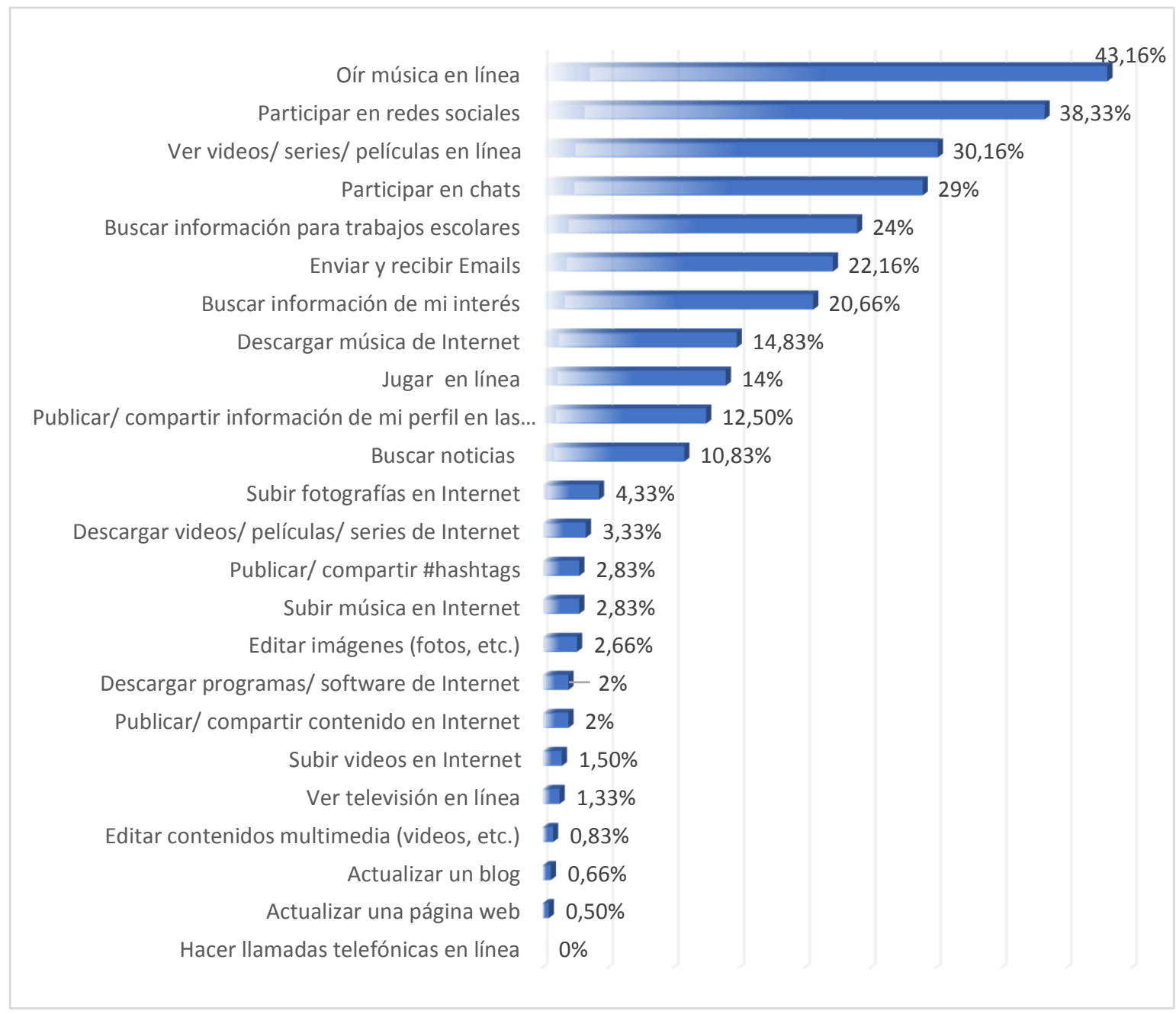

Fuente: elaboración propia

Al revisar la gráfica 4, importa señalar que actividades como envío y recepción de correos electrónicos $(22.16 \%)$, búsqueda de información (20.66\%), y descarga de contenidos (14.83\%), resultan secundarias. Estas prácticas, que parecen tener como denominador común una limitación para potenciar dinámicas de interacción y herramientas capaces de generar espacios de negociación de cultura/identidad juvenil. Se presenta de igual forma una prevalencia de los consumos realizados vía streaming, lo que indica una tendencia para la desmaterialización plena de los consumos y prácticas digitales (siendo el consumo televisivo la excepción a la regla). 
Por otra parte, podemos ver que las actividades que implican mayor disponibilidad, conocimientos y proactividad de los individuos (subir videos, música y fotografías, publicar/compartir contenidos, editar contenidos multimedia, actualizar un blog, actualizar una página web), aparecen aquí de forma marginal.

\section{Percibir prácticas intensivas; el uso de las redes sociodigitales}

Una de las prácticas cotidianas intensivas de los jóvenes encuestados es el uso de las redes sociodigitales. El 96.70\% de los jóvenes hacen uso de ellas como observamos en la gráfica 5, donde el $72.3 \%$ de los jóvenes encuestados afirma sólo tener un perfil en las Redes Sociodigitales, mientras que el $23.50 \%$ asegura tener dos perfiles o más.

\section{Gráfica 5. ¿Tienes un perfil o más de un perfil en las redes sociodigitales?}

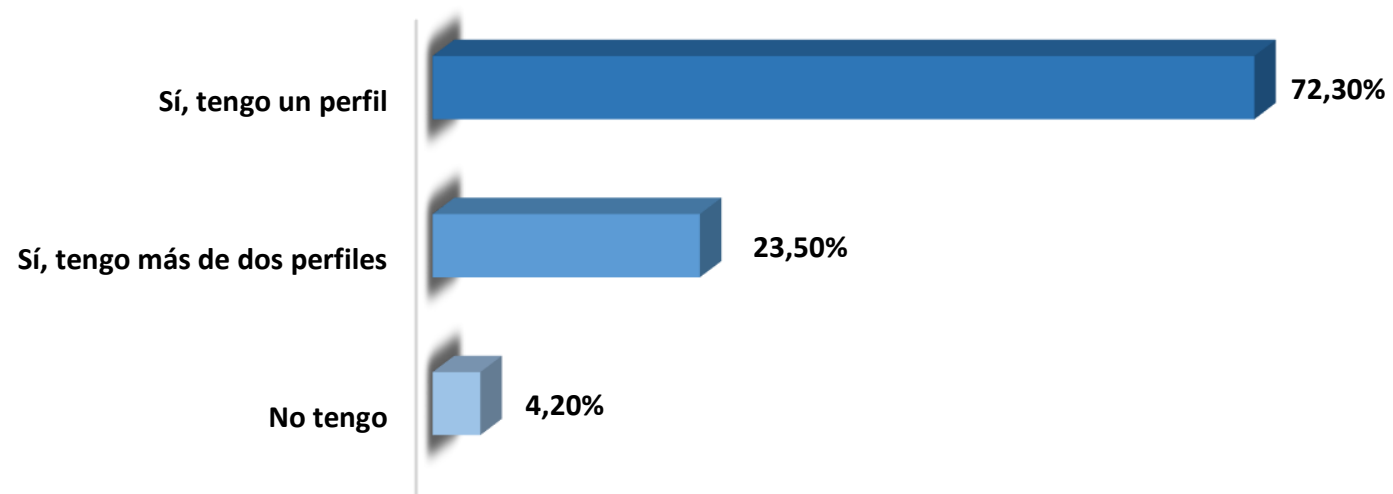

Fuente: elaboración propia

Este dato es sumamente interesante, permite percibir que cerca de 1/4 de los encuestado asume un desdoblamiento identitario en los múltiplos perfiles asumidos. Para entender las razones de esto es necesaria una aproximación complementaria de naturaleza cualitativa, que indague los motivos de los sujetos para este tipo de comportamiento.

Del 95.8\% de los jóvenes que afirmaron tener un perfil o perfiles en las Redes Sociales; el 83\% asevera tenerlo en la red social de Facebook y 
el 17 en Twitter. Los datos de la gráfica 6 permiten constatar que Facebook es la plataforma hegemónica de las prácticas digitales juveniles.

\section{Gráfica 6. ¿En qué redes sociales tienes perfil(es)?}

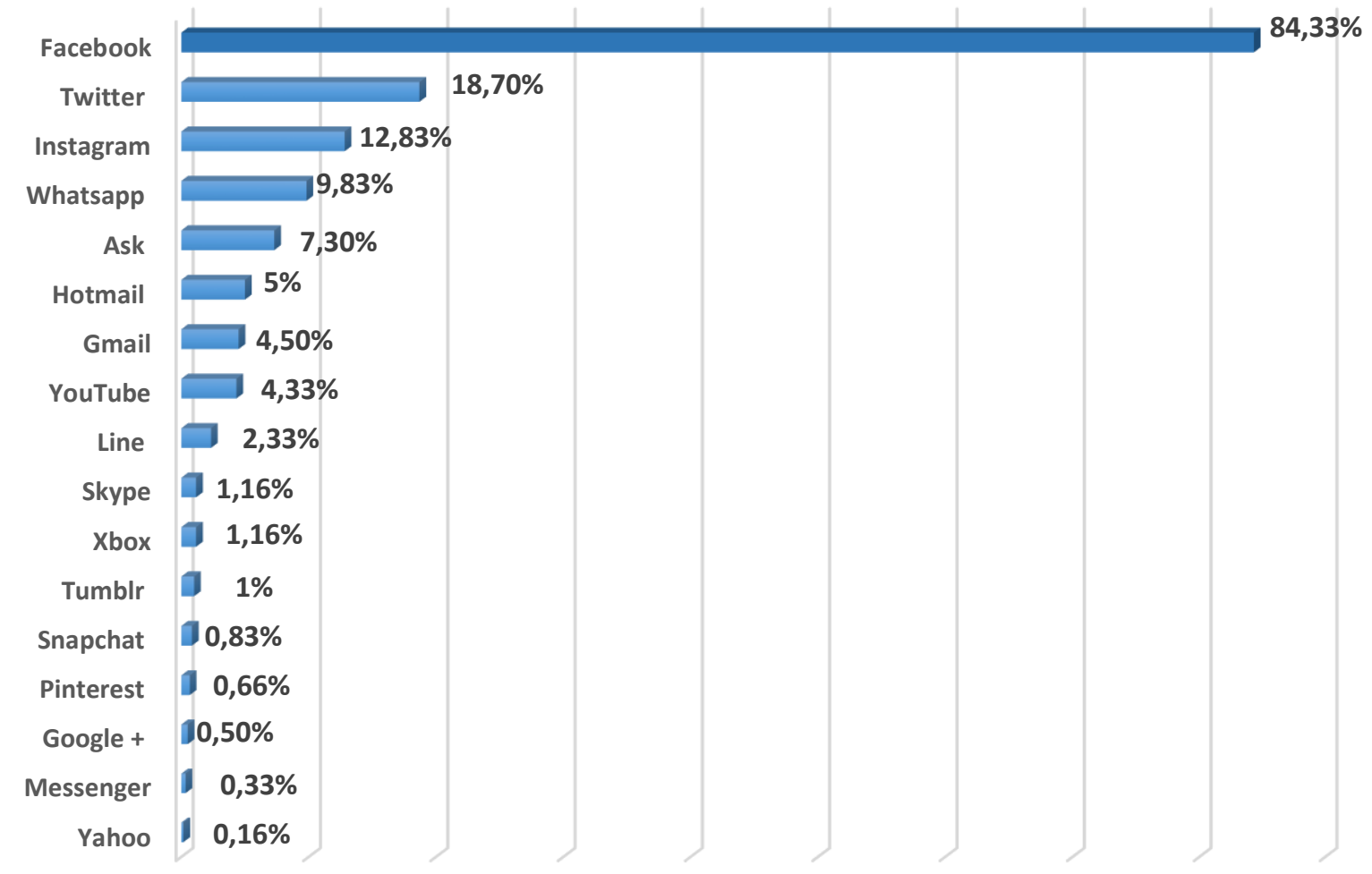

Fuente: elaboración propia

Recordemos que del $96.7 \%$ de los jóvenes encuestados que aseveran tener perfil (es) en las Redes Sociodigitales, el 43.80\% expresa tener un perfil "privado", el que sólo sus amigos pueden ver. Si consideramos los datos de la gráfica 7 , en que el $31.2 \%$ dice tener un perfil "parcialmente privado" (el que sólo sus amigos o los amigos de sus amigos lo pueden ver) y el $21.20 \%$ de ellos tienen perfiles "públicos" (el que toda la gente puede ver), constatamos que mitad de la muestra posibilita que personas fuera de su círculo de proximidad tenga acceso a información privada de los jóvenes. 


\section{Gráfica 7. Tu perfil o perfiles en las redes sociodigitales son:}

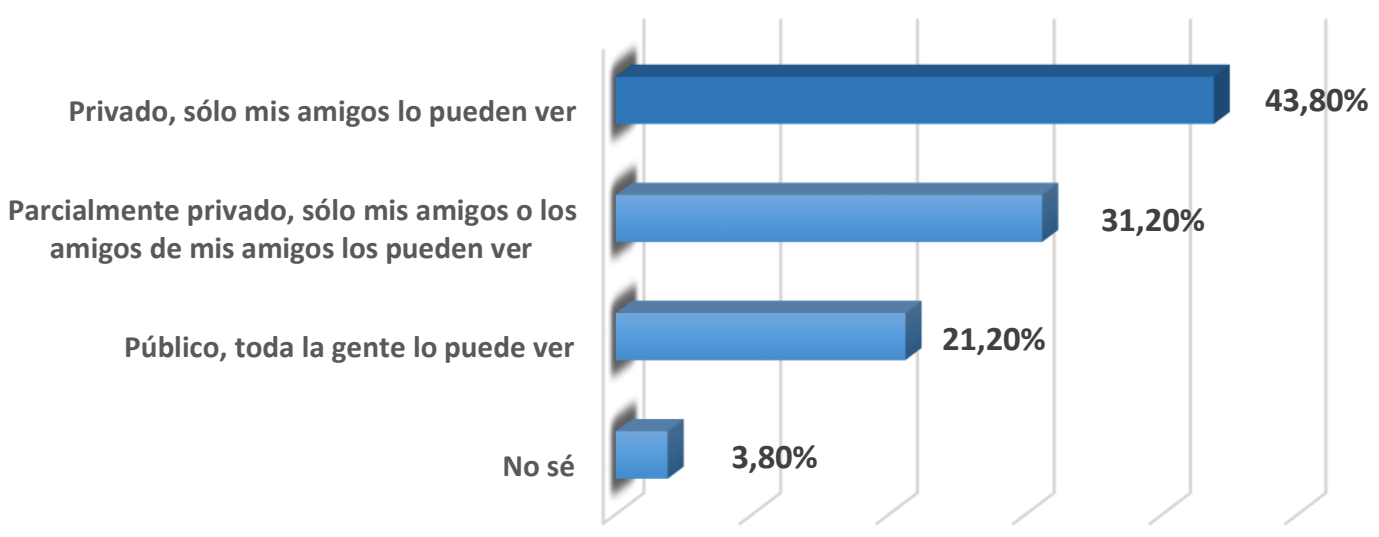

Fuente: elaboración propia

Como podemos verificar en la gráfica 8, el tipo de información que en su mayoría comparten los jóvenes en las redes sociodigitales son fotografías suyas (81.2\%), fotografías de sus amigos (63.33\%), su número de teléfono (52.7\%), seguido de su verdadero nombre (48.5\%). Prácticas en donde la privacidad de los datos personales, como el número telefónico, nombre y dirección, queda vulnerable por la exposición de cuestiones de la esfera íntima de los individuos que quebrantan la privacidad.

\section{Gráfica 8. ¿Qué tipo de información tienes en las redes sociodigitales que más utilizas?}

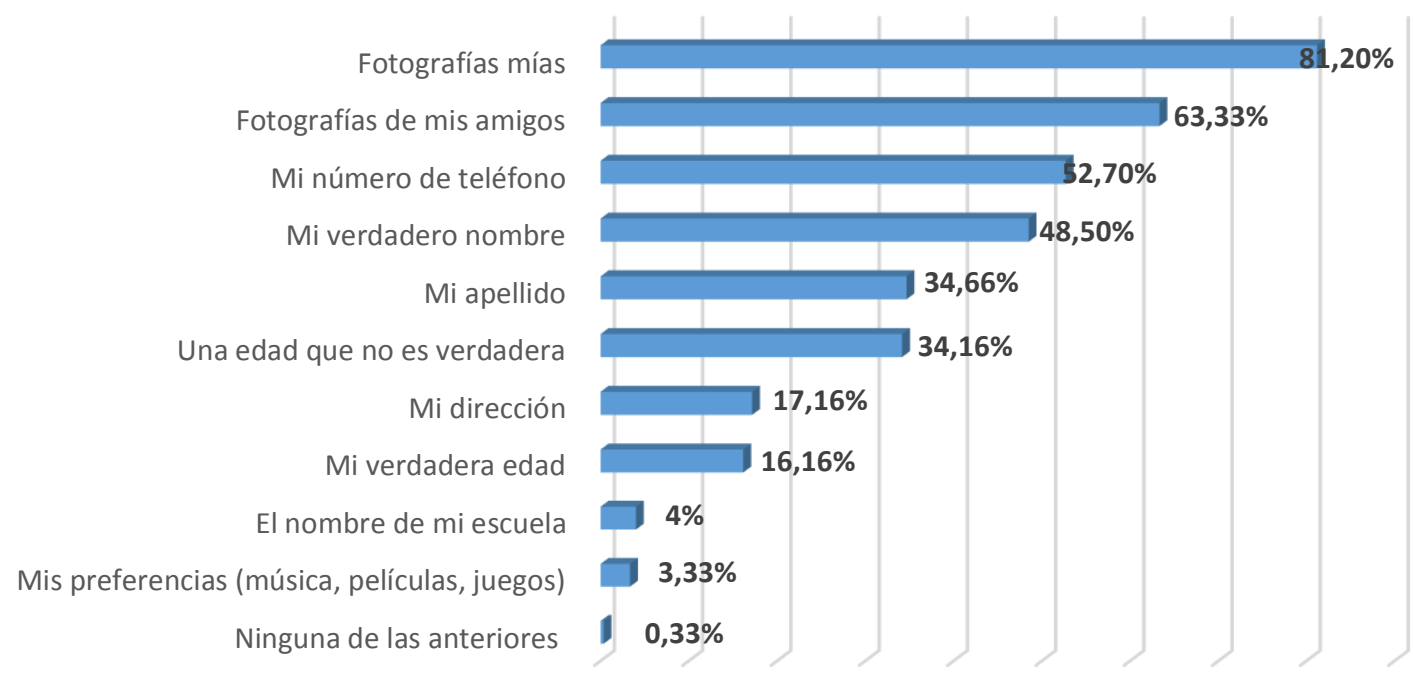

Fuente: elaboración propia 
Si analizamos los datos de la gráfica 9, acerca de los comportamientos en relación con cuestiones de privacidad un dato salta a la vista; el $65.70 \%$ de los jóvenes ha hecho configuraciones de privacidad para que sólo sus amigos puedan ver los contenidos que publican en las redes sociodigitales. Dato este que coincide en cierta medida, con las respuestas de la gráfica 7 , atendiendo al porcentaje de menos de la mitad $(43.8 \%)$ de los encuestados que ha expresado tener sus perfiles privados. La discrepancia puede estar asociada a la necesidad de responder con lo que es socialmente aceptable.

Por otra parte, el $22.3 \%$ asevera que nunca las ha cambiado, mientras que $6.20 \%$ de ellos asegura haber cambiado la configuración para permitir que todas las personas puedan ver sus contenidos. Únicamente el 3.70\% no tiene conocimiento sobre cómo hacer los cambios. Este tipo de prácticas nos habla de la posibilidad de los jóvenes de adquirir habilidades técnicas digitales para el uso de las plataformas sociales y pone en manifiesto la necesidad de repensar el proprio concepto de "nativo digital", que asume por defecto que los jóvenes socializados en contextos de cibercultura tienen competencias innatas para operar con los recursos tecnológicos.

\section{Gráfica 9. ¿Has cambiado alguna vez las configuraciones de privacidad en las redes sociodigitales?}

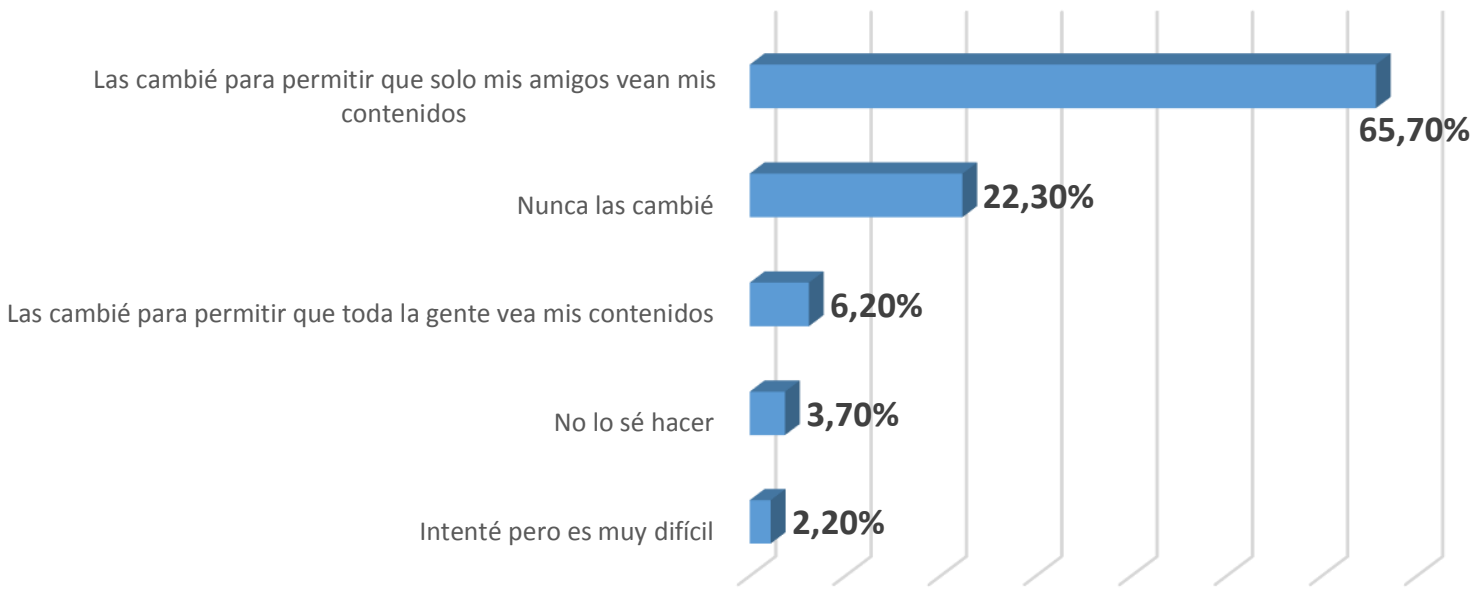

Fuente: elaboración propia

Uno de las componentes del estudio era también percibir en qué medida estos jóvenes adoptan en sus prácticas digitales comportamiento de riesgo. Preguntamos en qué medida Internet les 
permite entablar relaciones de naturaleza amorosa. El 57.7\% de los jóvenes niega haber ligado por Internet, mientras que el $42.3 \%$ afirma haberlo hecho. Esto demuestra que las plataformas se configuran como un espacio que permite establecer relaciones sociales afectivas/íntimas. Lo anterior se aprecia en la gráfica 10.

\section{Gráfica 10. ¿Has ligado por Internet?}

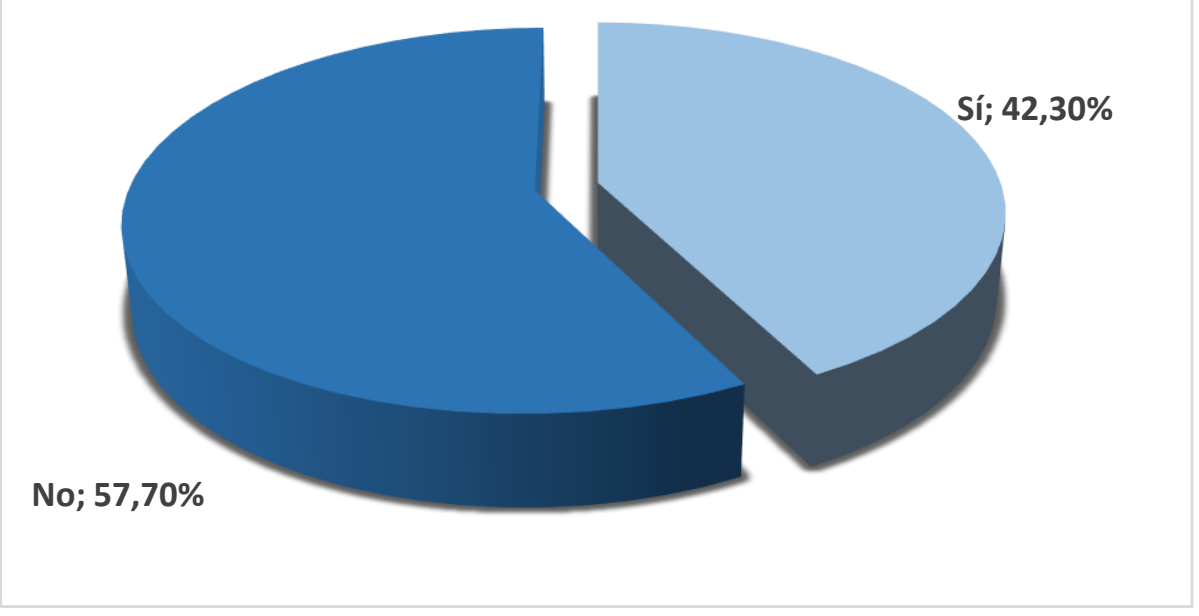

Fuente: elaboración propia

De ese $42.3 \%$ que afirmó haber ligado por Internet, el 30.8\% de los encuestados expresa que a quien ligó fue un(a) amigo(a), mientras que $8.20 \%$ ligó con un desconocido de la misma edad, y el 2\% no sabe la edad de la persona a la que contactó (gráfica 11). Interesante constatar que el porcentaje más significativo $(56 \%)$ corresponda a una categoría indefinida como "no se aplica", lo que puede denotar una dificultad en asumir que puede incurrir en prácticas de riesgo. Si consideramos que el segundo dato más significativo expresa que las relaciones amorosas se establecen con amigos, percibimos que las herramientas digitales son una extensión de las relaciones sociales presenciales, que se constituyen como herramientas que sirven para establecer vínculos emocionales y canales de seducción. Por otro lado, importa señalar que cerca de 10\% de los jóvenes se relacionó con desconocidos, una práctica que indicia un declarado comportamiento de riesgo que es necesario analizar en posteriores estudios (pensado en políticas públicas y campañas de sensibilización para los riegos digitales). 


\section{Gráfica 11. Si has ligado en Internet, ¿aa quién?}

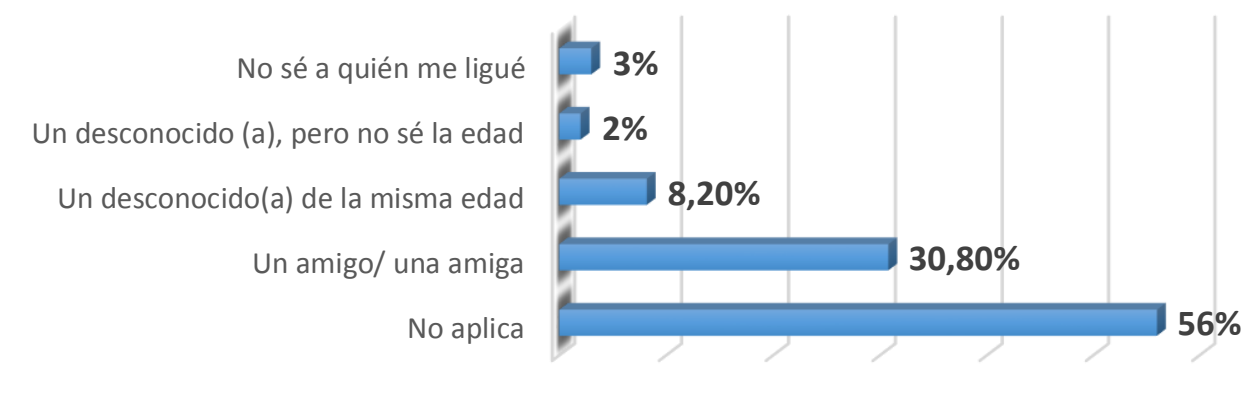

\section{Fuente: elaboración propia}

Ahondando en los riesgos asociados a prácticas digitales, se proponen dos cuestiones que se analizaron a la par. En un primer momento se indica un conjunto de situaciones de riesgo, preguntamos a los jóvenes en qué medida tenían conocimiento que sus amigos estuvieron expuestos a ellas (gráfica 12) y acto seguido, les preguntamos si ellos mismos vivieron esas situaciones (gráfica 13). Al analizar las cuestiones en conjunto se percibió que la (auto)percepción de riesgo es más severa respecto a comportamientos ajenos (del endogrupo) que propios.

\section{Gráfica 12. ¿Sabes si alguno(a) de tus amigo(a)s vivió alguna de estas situaciones...?}

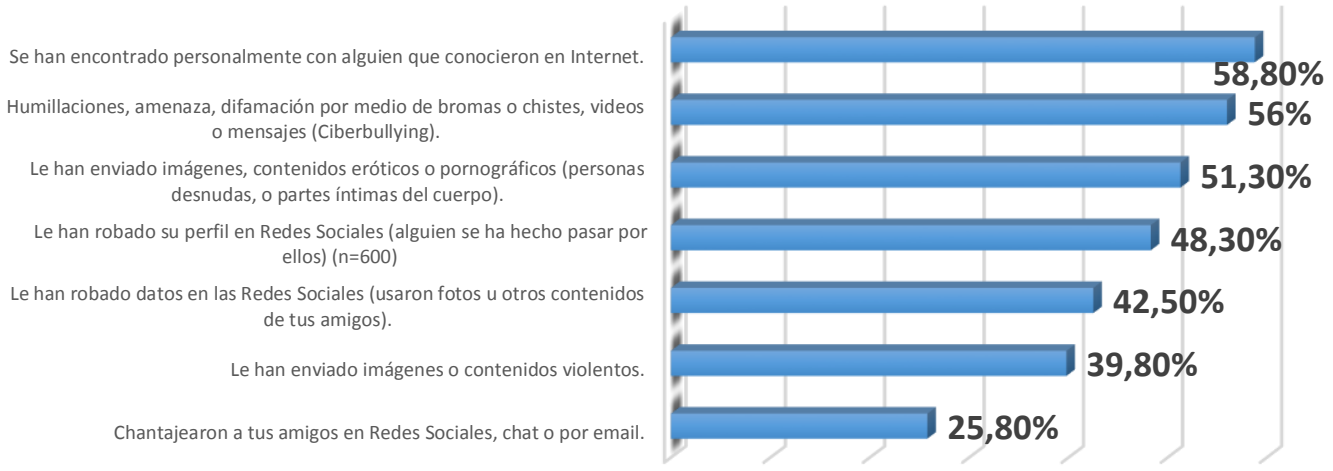

Fuente: elaboración propia

Basta para el efecto comparar las gráficas 12 y 13, se analiza cada una de las dimensiones de riesgo de forma comparativa entre las prácticas ajenas y propias: 1) Encontrase personalmente con alguien que conocieron en Internet: 58.8\% afirma que tiene conocimiento que algún amigo vivió esta situación frente al 39.30\% que admite haber pasado por esa situación; 2) Ser víctimas del cyberbullying en las Redes Sociales: $56 \%$ en los amigos vs $19.7 \%$ en su caso; 3 ) Recibir contenidos eróticos o pornográficos: $51.3 \%$ en los amigos vs $33.20 \%$ en su caso; 
4) Robo de perfil(es): $48.3 \%$ en los amigos vs $13 \%$ en su caso; 5) Robo de datos en las Redes sociales: $42.5 \%$ en los amigos vs $13.30 \%$ en su caso; 6) Recibir imágenes o contenidos violentos: $39.8 \%$ en los amigos vs $22.70 \%$ en su caso; 7) Chantaje: $25.8 \%$ en los amigos vs $11.30 \%$ en su caso. Estos datos formulan en nuestro entender la siguiente interpretación: pese a la distorsión en la evaluación de riesgos, constatamos que el cotidiano juvenil está permeado por innumerables situaciones de violencia que atraviesan las prácticas digitales de los jóvenes encuestados.

\section{Gráfica 13. ¿Y tú, has vivido alguna de estas situaciones?}
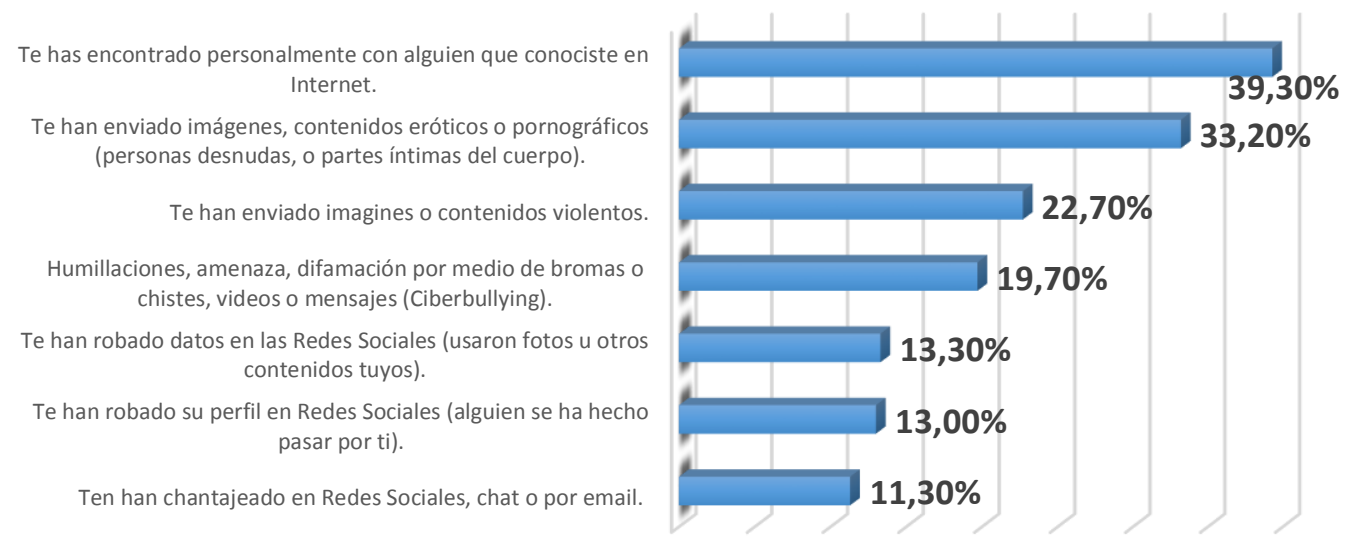

Fuente: elaboración propia

La última cuestión formulada (sistematizada en la gráfica 14) interrogaba a los jóvenes acerca de quiénes son los responsables de enseñar e informar cuestiones de seguridad y legalidad en Internet.

\section{Gráfica 14. ¿En tu opinión quién te debería enseñar o informar acerca de los riesgos en internet?}

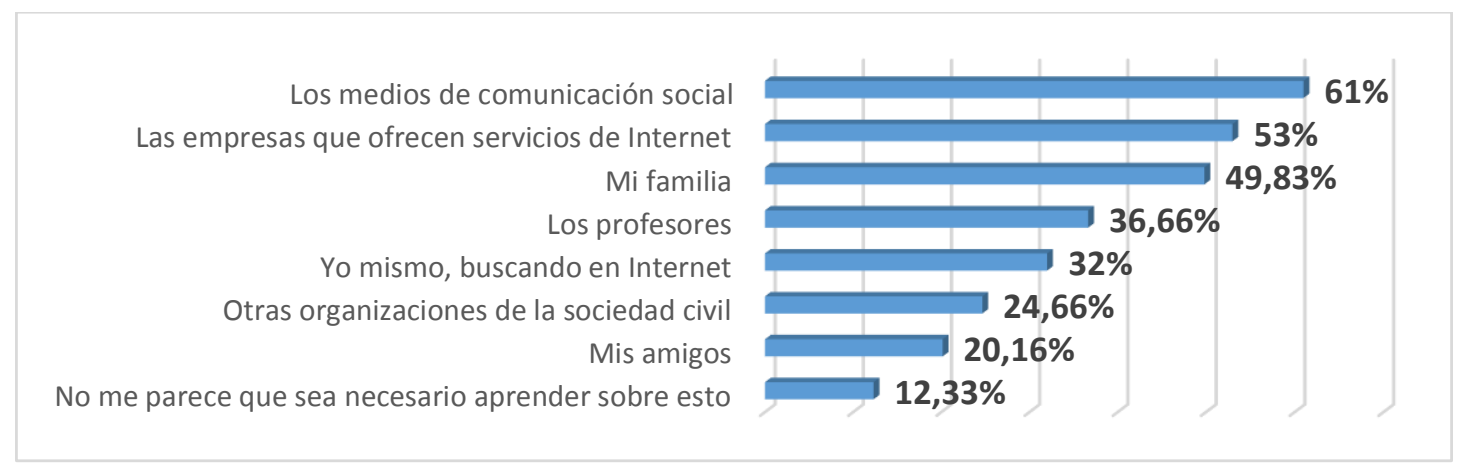

Fuente: elaboración propia 
La respuesta de los jóvenes atribuye a los medios de comunicación social, empresas que ofrecen servicios de Internet, familia y profesores la responsabilidad de enseñar e informar sobre las cuestiones de seguridad en Internet. Estos datos, desde la autopercepción de los jóvenes, suscitan la necesidad de una implicación efectiva de los agentes de socialización en el aprendizaje de operar en la red. La noción que parece subyacente es que los mismos agentes de socialización asumen que esta generación, "nativa digital", comporta en sí misma la capacidad de promover de forma absolutamente autónoma un autoaprendizaje de sus prácticas digitales. La demanda de los jóvenes deja de manifiesto la necesidad una nueva pedagogía para los medios, capaz de operar en los nuevos retos de las sociedades de información.

\section{Consideraciones finales}

Las evidencias aportadas por la discusión de los datos nos permiten afirmar que las prácticas juveniles online implican conductas de riesgo. Nuestro estudio, contestando a la pregunta de partida, refuerza la percepción de otras investigaciones previas, tanto en México, como en otros países que encuentran una correlación directa entre prácticas digitales y comportamientos de riesgo por parte de los jóvenes estudiados (Pacheco, Lozano y González, 2018; Livingstone et al., 2017).

Consideramos que las rutinas cotidianas de los adolescentes son construidas mediante prácticas intensivas online, conformadoras de la cultura juvenil. Las identidades, formateadas por el uso de redes sociales digitales, configuran lo que llamaríamos normalización del riesgo. Verificamos en porcentajes elevados un contacto directo por parte de los jóvenes con prácticas recurrentes que los colocan en situaciones de inseguridad (Catalina, Ayala y García, 2014).

Este comportamiento se hace efectivo por la naturalización del hecho de estar en la red, asumida como una extensión de la propia existencia, lo que deriva en una marcada dilución de la privacidad. De tal manera, verificamos que para los jóvenes encuestados las redes sociodigitales se han convertido: a) en espacios de mediación íntima, funcionando como 
si de un cupido electrónico se tratase, a la par de un territorio de seducción (mayoritariamente con amigos) ampliamente erotizado (donde extraños pueden participar); b) en contextos asumidos como controlados, por la posibilidad de permitir o negar el acceso, lo que naturaliza el compartir un conjunto de información personal e íntima, que claramente facilita la identificación efectiva de los sujetos.

Si a esto sumamos, desde una autopercepción de los adolescentes, que los riesgos son experimentados de forma más severa por los otros que por él mismo, no se atribuye efectiva importancia a la necesidad de alterar comportamientos online; no por desconocimiento de los riesgos, ya que cuando fueron cuestionados acerca del asunto, estos expresaron la necesidad de una proactividad por parte de los agentes de socialización para ayudarlos a adquirir una alfabetización digital, como ya había señalado García-Piña (2008).

Sensibilizar a los jóvenes acerca de una cultura del riesgo, inherente a sus actividades digitales, es fundamental para cambiar prácticas y actitudes (Livingstone et al., 2017). En sintonía con esta idea, Unicef (2017) propone la necesidad del diseño de políticas públicas para paliar este problema. Para tal efecto, sería necesario que las prestadoras de servicios de internet cumplan efectivamente las leyes vigentes, no permitiendo acceso a determinados contenidos a menores. De forma complementaria sería necesario asegurar que los periodistas dieran visibilidad al tema de riesgos, que los profesores y los padres fueran capacitados para ayudar a los jóvenes a operar de forma segura y no sean vistos solamente como agentes de restricción.

Esta argumentación pone de manifiesto la importancia de discutir el proprio concepto de nativos digitales, que como apuntamos en la presentación de datos, por defecto asume que una socialización construida desde la cuna, por mediación tecnológica, capacita a los jóvenes para aprovechar las potencialidades de los recursos digitales, incluida la conciencia acerca de los riesgos inherentes a su uso. Los estudios empíricos lo desmienten y amplifican la necesidad de diseños de políticas públicas que puedan contribuir a disminuir riegos y a ensanchar el uso de las herramientas digitales, por ejemplo, como instrumentos de participación cívica. 


\section{Referencias}

Asociación de Internet.mx (2018). 14 Estudio sobre los bábitos de los usuarios de Internet en México. Recuperado de https://www.asociaciondeinternet.mx/es/component/remosit ory/Habitos-de-Internet/14-Estudio-sobre-los-Habitos-de-losusuarios-de-Internet-en-Mexico-2018/lang,es-es/?Itemid=

Bernete, Francisco (2010). Los usos de las TIC, relaciones sociales y cambios en la socialización de las y los jóvenes, en Revista de Estudios de Juventud no 88 (pp. 97-114). España: INJUVE.

Bossolasco, M. y Storni, P. (2012). ¿Nativos Digitales?. Una reflexión acerca de las representaciones docentes de los jóvenes-alumnos como usuarios expertos de las nuevas tecnologías. Análisis de una experiencia de inclusión de las TIC en la escuela. Revista de Educación a Distancia $\mathrm{n}^{\circ} 30$. Recuperado de https://www.um.es/ead/red/30/bossolasco.pdf

Bauman. Z. (2016) Las redes sociales son una trampa. El País. Recuperado de https://elpais.com/cultura/2015/12/30/babelia/1451504427 675885.html

Catalina, B., Ayala, M., y García, A. (2014). Los riesgos de los adolescentes en Internet: los menores como actores y víctimas de los peligros de Internet. Revista Latina de Comunicación Social, 69, 462-485.

Castellana, M., Sánchez, X., Graner, C., y Beranuy, M. (2007). El adolescente ante las tecnologías de la información y la comunicación: internet, móvil, videojuegos. Papeles de Psicólogo, 28(3), 196-204.

Cohen, S. (1972). Folk devils and moral Panics. London: MacGibbon and Kee.

ComScore (2016). Futuro Digital 2016. Recuperado de https://www.comscore.com/lat/Prensa-yEventos/Presentaciones-y-libros-blancos/2016/2016-GlobalDigital-Future-in-Focus

Crovi, D. (2009). Acceso, uso y apropiación de las TIC en comunidades académicas. Diagnóstico en la UNAM. México: UNAM y Plaza y Valdez Editores. 
Crovi, D. (Coord.) (2016). Redes sociales digitales. Lugar de encuentro, expresión y organización de los jóvenes. México: UNAM.

Dans, E. (2017). Jóvenes y Redes sociales, más complejo de lo que parece. Telos, 107, España: Fundación Telefónica.

Del Barrio, Á., y Fernández, I. R. (2016). Los adolescentes y el uso de las redes sociales. International Journal of Developmental and Educational Psychology. Revista INFAD de Psicología, 3(1), 571-576.

Domínguez, y Pérez. (2015). Uso de las redes sociales digitales entre los jóvenes universitarios en México. Hacia la construcción de un estado del conocimiento (2004-2014). Revista de Comunicación 14. México. Recuperado de https://revistadecomunicacion.com/pdf/2015/Art048-069.pdf

Espinar E. y López C. (2009). Jóvenes y adolescentes ante las nuevas tecnologías: percepción de riesgos. Athenea Digital. Recuperado de http://psicologiasocial.uab.es/athenea/index.php/athenea Digital/article/view/509

García-Piña, Corina (2008). Riesgos del uso de internet por niños y adolescentes. Estrategias de seguridad. Acta Pediátrica de México, 29 (5), 272-278.

Giménez, G. (2005). Teoría y análisis de la cultura. Volumen Uno y Dos. México: CONACULTA.

Hansson, S. O. (2002). Las inseguridades en la sociedad del conocimiento. Revista Internacional de Ciencias Sociales, 171, 1-12.

Livingstone, S., Davidson, J., Bryce, J., Batool, S., Haughton, C. \& Nandi, A. (2017). Children's online activities, risks and safety: a literature review by the UKCCIS evidence group. UKCCIS Evidence Group Literature Review. LSE Consulting. London: LSE. Isaak, F. (2014). Propuesta de Estrategia Docente: El uso de Facebook como espacio para promover el trabajo colaborativo (T.C.) fuera del aula, en la licenciatura de Psicología Educativa de la Universidad Pedagógica Nacional. AMIC (Eds.). Memoria electrónica del XXVI Encuentro Nacional de AMIC. San Luis Potosí, México: AMIC.

Islas, C. y Carranza, M. (2011). Uso de las redes sociales como estrategias de aprendizaje ¿'Transformación educativa? Revista de innovación educativa, 2. Recuperado de:

http://www.udgvirtual.udg.mx/apertura/index.php/apertura3/ article/view/198/213 
Jackson, L. A., Zhao, Y., Kolenic III, A., Fitzgerald, H. E., Harold, R. \& Von Eye, A. (2008). Race, gender, and information technology use: The new digital divide. CyberPsychology and Behavior, 11 (4), 437-442

Lévy. P. (2007). Cibercultura. La cultura de la sociedad digital. Barcelona: Anthropos/UAM.

Levine, L. E., Waite, B. M. \& Bowman, L. L. (2007). Electronic media use, reading, and academic distractibility in college youth. CyberPsychology and Behavior, 10 (4), 560-566.

Milani, L., Osualdella, D. \& Di Blasio, P. (2009). Quality of interpersonal relationships and problematic internet use in adolescence. CyberPsychology and Behavior, 12(6), 681-684.

Marciales, V. G. P. y Cabra, T. F. (2011). Internet y pánico moral: revisión de la investigación sobre la interacción de niños y jóvenes con los nuevos medios. Universitas Psychologica, 10 (3), 855-865.

Margulis, M. (2001). Juventud: una aproximación conceptual. En S. Dones (Comp.). Adolescencia y juventud en América Latina. Costa Rica: LUR.

Medina, G.L., Romero, G.R., y González, C.P, (2011). Regresando a lo básico: un estudio sobre el potencial didáctico de twitter en educación superior. COMIE (Eds.). Memoria electrónica del XI Congreso Nacional de Investigación Educativa. UNAM, Ciudad Universitaria, México, D.F.

Meneses, M. y Pérez, G. (2016). Cómo y qué se estudia sobre Internet y la Sociedad de la Información en México. Una mirada desde la AMIC. Comunicación y Sociedad. 26, 43-70.

Morales, M., Lavigne, G., y Mercado, M. (2016). Apropiación tecnológica de estudiantes rurales adscritos a una universidad virtual. EDUTEC Revista Electrónica de Tecnología Educativa. No. 55/marzo, pp. 1-13. México. Recuperado de http://www.edutec.es/revista/index.php/edutece/article/view/645/Edutec n55 Morales Lavigne Mercado

Organización Mundial de la Salud (2013). Factores de riesgo. Recuperado de http://www.who.int/topics/risk_factors/es/

Ortíz, G. (2012). L@s jóvenes y su relación con la red internet: de la adicción al consumo cultural. Recuperado de 
http://ww35.razonypalabra.org.mx/varia/N78/2a\%20parte/27 Ortiz V78.pdf

Pacheco, B., Lozano, J., y González, N. (2018). Diagnóstico de utilización de Redes sociales: factor de riesgo para el adolescente. RIDE, 8(16).

Pereira, F., Spitzberg, B. y Matos, M. (2016). Victimización por acoso cibernético en Portugal: prevalencia, temor y búsqueda de ayuda entre adolescentes. Computadoras en el comportamiento bumano, 62, 136-146. http://dx.doi.org/10.1016/j.chb.2016.03.039

Premsky, M. (2001). Digital natives, digital immigrants. On The Horizon, 9(5), pp. 1-6. Recuperado de https://www.marcprensky.com/writing/Prensky $\% 20$ $\% 20$ Digital $\% 20$ Natives, $\% 20$ Digital $\% 20$ Immigrants $\% 20$ \%20Part1.pdf

Rodríguez, S. (2011). Maestra, ¡Vamos a odiar al face!, SOMECE (Eds.). Memoria electrónica del $27^{\circ}$ Simposio Internacional SOMECE. México: SOMECE.

Rosabal, E., Romero, N., Gaquín, K., y Hernández, R. A. (2015). Conductas de riesgo en los adolescentes. Revista Cubana Medicina Militar, 44(2), 218-229.

Rubio, A. (2010). Jóvenes y nuevos medios de comunicación. España: INJUVE. Recuperado de http://www.injuve.es/sites/default/files/RJ88-15.pdf

Sandoval, R., Romero, A., y Heredia, E. (2013). Comunicación e intercambio con redes sociales en la educación universitaria: caso estudiantes de Administración e Informática. Revista Electrónica Apertura, 5 (2), 1-30.

Serapio, A. (2006). Realidad Pisocosial: la adolescencia actual y su temprano comienzo. Revista de estudios de Jwentud, 73, 11-23. Tarín, M.; Navarro J. (2006). Adolescentes en riesgo. Casos prácticosy estrategias de intervención socioeducativa. Madrid: Editorial CCS.

Tully, C.J. (2007). "La socialización en el presente digital.

Informalización y contextualización”. Revista CTS, 8(3), 9-22. Unicef (2017). Niños en un mundo digital. Nueva York: Unicef.

Urteaga, M. (2007). La construcción juvenil de la realidad. (Tesis inédita de doctorado en Antropología). México: Universidad Autónoma Metropolitana-Iztapalapa. 
Van Grove, J. (2013). ¿Por qué los adolescentes se están cansando de Facebook? Recuperado de https://www.cnet.com/news/whyteens-are-tiring-of-facebook/

Watts, D. J. (2007). A twenty-first century science. Nature, 445, 489. http://dx.doi.org/10.1038/445489

Winocur, R. (2006). Internet en la vida cotidiana de los jóvenes.

Revista Mexicana de Sociología 68(3), 551-580. 



\title{
Estar en las redes para salir de las redes: comunidades sociodigitales y participación ciudadana en Argentina ${ }^{31}$
}

\author{
Malvina Eugenia Rodríguez \\ Universidad Nacional de Villa María (Argentina) \\ malvirodriguez@gmail.com
}

PARA CITAR: Rodríguez, M. E. (2019). "Estar en las redes para salir de las redes: comunidades sociodigitales y participación ciudadana en Argentina”. En Barredo Ibáñez, D.; Cunha, M. R. \& Hidalgo Toledo, J. (Eds.) (2019). Jóvenes, participación y medios de comunicación digitales en América Latina <pp. 165-176>. La Laguna, España: Cuadernos Artesanos de Comunicación. DOI: 10.4185/cac156

\begin{abstract}
El trabajo analiza "comunidades sociodigitales" en Argentina, que se manifiestan tanto en redes sociales como en tradicionales ámbitos de participación ciudadana, a fin de establecer agendas y ejercer influencia política.
\end{abstract}

\footnotetext{
31 Trabajo basado en la ponencia presentada en el XIV Congreso de la Asociación Latinoamericana de Investigadores de la Comunicación (ALAIC) Comunicación en sociedades diversas: Horizontes de inclusión, equidady democracia. San José, Costa Rica, 30, 31 de julio y 1 de agosto 2018. GT 19: Comunicación digital, redes y procesos. Artículo enmarcado en los proyectos de investigación "Participación ciudadana y estrategias sociodigitalizadas en nuevas expresiones del conflicto social en Argentina y Brasil" (2016-2017) y "Comunicación política sociodigital: comunidades y partidos en red en América Latina” (20182019), desarrollados en el Instituto Académico Pedagógico de Ciencias Sociales (IAPCS) de la Universidad Nacional de Villa María.
} 
Keywords: redes sociales, sociodigital, participación ciudadana.

\section{Introducción}

L

AS EXPRESIONES actuales del conflicto social en América Latina remiten a nuevas formas de comunicación y participación ciudadana que implican la construcción de "realidades sociodigitalizadas", es decir, la configuración del espacio público a partir de la publicidad que adquieren discursos privados, individuales o grupales a través de las redes sociales y de entornos de virtualidad, en tanto la cobertura mediática participa reconstruyendo dichos entornos y por ende, los canales de participación ciudadana en el espacio público (Rodríguez \& Theiler, 2016a).

Esta investigación se propone describir las características de estos espacios de participación de la sociedad civil argentina y su capacidad para impactar en las agendas domésticas en el marco latinoamericano, debido a procesos políticos vinculados en la región. Para ello se aborda el proceso de construcción de ciudadanía teniendo en cuenta el sentido de pertenencia que poseen las sociedades sobre su condición de "comunidades sociociodigitales". Con este concepto, nos referimos a la particular relación entre la construcción discursiva y la participación de las personas en los mundos "online" y "offline", dinamizando y complejizando el espacio público.

El objeto se abordó mediante un relevamiento de redes, medios, canales y espacios de participación ciudadana en entornos sociodigitalizados en Argentina. A partir de esta exploración, se realizaron entrevistas a referentes de organizaciones sociales con demostrado uso de TIC en sus estrategias de comunicación pública, que utilizan las tecnologías digitales como medios de expresión para tratar el conflicto social.

Este trabajo propone una discusión teórica sobre el estado de la cuestión en relación a la construcción de participación ciudadana en la sociodigitalización de las protestas sociales y de la organización ante situaciones de conflicto. Asimismo, se presentan algunas observaciones vinculadas al relevamiento de comunidades 
sociodigitales en Argentina y a las expresiones vertidas por activistas digitales.

\section{Convergencia comunicacional y participación ciudadana}

La cultura de la conectividad, como denomina José Van Dijck (2016) a la reconfiguración cultural que provocan las redes sociales, responde a la transformación comunicacional de la sociedad red que implica el pasaje de la comunicación de masas a la "autocomunicación de masas" (Castells, 2009). El ciberactivismo responde a la autoproducción y, a través de la viralización, a la reproducción de la protesta por medio de la publicidad que adquieren los discursos privados de los manifestantes en el espacio público, ampliado tanto por los mismos medios sociales como por la replicación de los medios tradicionales. Esta cultura de la conectividad representa también, mediante la algorrítmica conexión de los discursos, una cultura de convergencia (Jenkins, 2008; Ferre Pavia, 2014).

Como manifiesta Van Dijck (2016), "los mundos online y offline se muestran cada vez más interpenetrados", lo cual permite hablar de una realidad transmediática, pero además "sociodigitalizada". La construcción y reconstrucción de "realidad social" se dinamiza por la participación de los actores en el espacio público político (políticos, periodistas y ciudadanos) en un contexto de configuración autónoma (no necesariamente independiente pero tampoco de respuesta masiva) de los discursos, en un complejo espacio de interacción en redes que reconfiguran realidades sociodigitalizadas.

Ahora bien, la realidad sociodigitalizada implica, en su dimensión social, la presencia de nuevos movimientos sociales como manifestaciones de demandas e injusticias sociales, algunas de las cuales son formas renovadas de reclamos históricos. En su dimensión digital, significa la configuración y renovación permanente de espacios virtuales de construcción discursiva: el ciberactivismo que pasó del correo electrónico y el blog a la telefonía digital y de allí a las redes sociales, con proyecciones futuras aún inciertas. 
Las características principales de esta nueva forma de configuración de lo social son, por tanto, la virtualidad y la conexión en red. Por un lado, se acuerda en que "ese nuevo espacio es virtual porque permite jugar con imágenes, palabras y contextos en la construcción de espacios paralelos que constituyen escenarios de realidad virtual que acaban por moldear la propia realidad" (Ferre Pavia: 2014, p. 48). Por otro lado, la sociabilidad del siglo XXI acontece como una manifiestación biopolítica (Foucault, 2007) de una característica siempre existente en la humanidad desde las primeras formaciones político-culturales, pero que en el presente adquiere preeminencia sobre otras formas anteriores: la sociabilidad en red. En palabras de Castells (1996): "Las redes informáticas interactivas crecen de modo exponencial, creando nuevas formas y canales de comunicación, y dando forma a la vida a la vez que ésta les da forma a ellas".

Pero a esta sociodigitalización le corresponde también una presencia física en el espacio público, de apropiación de la plaza o de la calle, que aún está presente en la convocatoria ciberactivista de muchos movimientos sociales. Algunos de ellos deben a la presencia masiva en las calles su impacto internacional, como por ej. el movimiento feminista por la lucha contra la violencia machista "Ni Una Menos", surgido en 2015 en Argentina y de amplio alcance mundial en la actualidad.

En esa nueva configuración del espacio público, "los discursos mediáticos, hasta el momento con reconocida y privilegiada capacidad de nominación e imposición de sentidos, se reconfiguran con los mensajes de los entornos virtuales y las realidades múltiples resultan fenómenos sociales a partir de los cuales se pueden observar las formas que adopta la recurrente disputa por la nominación del mundo social, su ordenamiento y sus posibilidades de transformación" (Rodríguez y Theiler, 2016b, p. 153). En consecuencia, observamos a los nuevos movimientos sociales y sus particulares y cambiantes formas de participación como "comunidades sociodigitalizadas o sociodigitales" 32 .

\footnotetext{
32 Si bien en estudios, ponencias y publicaciones anteriores hemos utilizado la denominación "sociodigitalizada" también para las comunidades, optamos aquí
} 
Entendemos por comunidades sociodigitales a las nuevas expresiones de autocomunicación de masas que se manifiestan tanto en los espacios de conectividad digital como en los tradicionales ámbitos de participación en el espacio público, con la intención de establecer agendas y tematizar cuestiones de interés social en diferentes ámbitos de incumbencia. Estas comunidades se manifiestan principalmente en redes sociales pero también interactúan en otros entornos de virtualidad como blogs o páginas web.

La particularidad de estas comunidades resulta, entonces, su presencia activa tanto en los mundos "online" como offline", por lo cual se caracterizan por la hibridación de formatos y lenguajes, tanto en la construcción discursiva como en la selección de canales de participación. Por ej., dinamizan sus intervenciones y lecturas de la agenda pública mediante géneros híbridos como el infotainment.

El infoentretenimiento fue un término orginado en los años 80 para denominar a la difuminación de fronteras en los medios de comunicación masivos, pero también en las prácticas políticas y culturales, entre la lógica de la producción y circulación de información propiamente dicha (noticia que reduce incertidumbre) y la lógica del entretenimiento, que refuerza la espectularización para asegurar la diversión y se rige por la lógica mercantil. En la cibermilitancia se observa cada vez más la presencia del infoentretenemiento, tanto en el demoninado "marketing digital" de las campañas electorales como en los nuevos movimientos sociales en red, o comunidades sociodigitales, en tanto se hace uso intensivo de una hibridación de géneros como el humor, la sátira, el drama, el melodrama (Ferre Pavia, 2014), como se puede observar en los "memes", muy difundidos en redes sociales como Facebook o Twitter.

El nuevo espacio público encuentra una militancia sociodigitalizada que parece haberse apropiado de las tecnologías antes de que lo hicieran las instituciones políticas o los medios de comunicación tradicionales. En este nuevo espectro de división de poderes y discursos legítimos, la sociedad se convirtió en protagonista de la

por la forma simplificada (sociodigital), sin desconocer que se trata asimismo de procesos. 
convergencia digital (Ferre Pavia, 2014). Si bien el origen de los nodos de la producción de sentidos resultan difíciles de establecer en cada caso, la forma reticular de las conexiones se observa como un basamento que necesita extenderse para disputar la apropiación del espacio público, no sólo del virtual sino, y fundamentalmente, del político.

Un ejemplo de estas reconfiguraciones de lo público y lo informacional en, como lo denomina Van Dijck (2016), el nuevo "ecosistema de medios conectivos", puede ejemplificarse con el primer relevamiento en Argentina de medios de comunicación digitales o medios sociales de comunicación digital, como propuestas alternativas a los medios tradicionales. Asimismo, las comunidades sociodigitales se constituyen en el lugar de construcción de contrapoderes que permiten la organización y visibilización para la participación ciudadana en el espacio público político. A continuación, presentamos algunas reflexiones sobre estas nuevas formas de participación sociodigitalizada.

\section{De la comunicación masiva a la autocomunicación de los medios sociales}

Se consideran aquí los medios sociales de comunicación digital (MSCD), a diferencia de versiones digitales de los tradicionales medios de comunicación masivos (MCM), a aquellos que se definen como tales a la hora de presentarse, en tanto se posicionan como alternativos a los MCM, se elaboran en versiones exclusivamente online y se difunden través de páginas web y/o redes sociales.

En general, construyen un tipo de texto bajo el formato tradicional de la noticia que se utiliza en la prensa gráfica. Sin embargo, presentan variaciones entre ellos, algunos por ej. proponen mediaciones basadas en formatos híbridos que cabalgan entre el periodismo político y el literario.

Son medios que se ubican en una línea editorial clara y explicitada, que tienen su propia página web, su fan page o perfiles en las redes sociales, y que se valen de todas las plataformas posibles, incluso sin descartar 
los medios considerados tradicionales, como versiones impresas, canales o programas de radio o televisión, a fin de cumplir con el objetivo de llegar con su mensaje a sus públicos meta. Además, suelen avanzar en la utilización del WhatsApp como medio para la distribución de la información, demostrando creatividad y comprensión de cuáles son los soportes más utilizados por las audiencias para la información de actualidad.

En todos los casos se trata de contenidos a los que se accede de manera gratuita, con la única exigencia de contar con un dispositivo móvil. En decir, con la disponiblidad de un teléfono celular inteligente y la conexión a internet, generalmente por wi-fi, se alcanza el acceso a estos medios. Otra de las características es que realizan un abordaje multitemático, utilizando las distintas plataformas a su alcance (incuso de medios radiales y ediciones digitales de periódicos). En el caso de los medios seleccionados en esta investigación, al menos tres de los MSCD tienen una distribución topográfica de la información en secciones, en tanto mapa organizativo de los textos, siguiendo la concepción tradicional de la prensa gráfica.

En general, los MSCD plantean otro concepto de lo alternativo, que marca una diferencia con los MCM a veces en la agenda publicada y, sobre todo, en la construcción del texto informativo, con una mirada desde lo popular y en defensa de causas que generan conflicto social por la situación de injusticia que suponen (por ej. contaminaciones medioambientales en barrios de cordones periurbanos donde se ubican los sectores más pobres de la sociedad). Incluso alguno de estos medios trascienden su propuesta como medios de comunicación para convertirse en verdaderas organizaciones sociales, aunque la determinación del origen del juego sociodigital, como se dijo anteriormente, es difícil de determinar. La propia dinámica reticular que caracteriza a estos MSCD dificulta el rastreo de qué fueron primero, si organización social o medio.

Los MSCD desarrollan, desde la información, sus propias estrategias para hacerle frente a los medios hegemónicos. Incluso avanzan en ideas creativas para sortear las limitaciones en recursos financieros, de manera de no depender de la publicidad. De hecho, algunos de los 
medios relevados ofrecen a los seguidores/usuarios/suscriptores la posibilidad de hacer donaciones por única vez o de manera periódica.

Los MSCD en Argentina analizados fueron: Agencia Paco Urondo, Izquierda a Diario, InfoSiberia, En Orsai, La Tinta, NotiEnRed, Cosecha Roja, En Redacción. Este primer relevamiento permite observar un ecosistema mediático en red con ciertas particularidades: preeminencia del modelo de periodismo militante, pero con presencia de medios que, sin desconcer su raigambre alternativa a los medios hegemónicos, comprenden su rol de constructores de realidad o tienen a posicionarse como opciones cercanas al ideal objetivista de la información periodística. Coinciden también en una concepción de la comunicación como derecho humano. Además, se esfuerzan por mantenerse independientes de la publicidad comercial y apuestan al compromiso de sus lectores con la sustentabilidad del medio mediante estrategias innovadoras. Con igual creatividad extienden sus ámbitos de influencia a distintas redes y posibilidades tecnológicas sin renunciar al acceso abierto y gratuito.

Por todas estas razones, constituyen comunidades de pertenencia y participación como signo del contrato de lectura con sus públicos, los que son convocados muchas veces a desarrollar activamente un periodismo ciudadano que lleva a nuevas fronteras el lugar de prosumidor que desde tiempo se le asigna a las anteriormente consideradas audiencias pasivas. Finalmente, el conflicto, la disputa por el establecimiento de agenda y de sentidos se convierte en central en la construcción discursiva de un periodismo que, de manera autonóma, renuncia a los condicionamientos de la comunicación de masas para corresponderse a la era de la autocomunicación.

\section{Estar online para actuar offline: comunidades sociodigitales para la militancia de género}

Uno de los MSCD analizados, La Tinta, ejemplifica la militancia periodística y ciudadana en el ámbito de la defensa de los derechos humanos, particularmente en relación a temáticas de género. La Tinta se origina en la provincia de Córdoba en agosto de 2016. Se presenta como medio de comunicación, bajo el lema "Periodismo hasta 
mancharse". Se autodefine como "una herramienta para recuperar la vOz, visibilizar nuestras luchas, nuestras demandas y nuestras victorias; compartir las miradas sobre el mundo, la realidad y difundir las alternativas que estamos caminando". Ofrece la aclaración de que "los medios, periodistas y colectivos que colaboran no necesariamente comparten la línea editorial de todo el contenido difundido por La Tinta". En tal sentido, si bien puede inscribirse en el paradigma de periodismo militante, comparte algunas características de la perspectiva contructivista en cuanto a la posibilidad de diversidad de miradas e interpretaciones y se aleja de la toma de posición manifiesta, sobretodo de adhesión ideológica o afiliación partidaria. Su tratamiento de la información manifiesta una clara perspectiva de género, desde el paradigma feminista. La Tinta ofrece la posibilidad de colaborar en el manteniento del medio con una propuesta cargada de humor e ironía en la pestaña "Dueña", donde alienta a la audiencia a asociarse con una colaboración monetaria mínima mensual.

En el caso de la Tinta observamos una reconfiguración de los parámetros del periodismo tradicional, en tanto la propuesta se basa en la visibilización del conflicto para promover la movilización ciudadana, que una vez producida cuenta además con una cobertura especial tanto en la propuesta estética (fotografías de alto impacto) como en la interpretativa (análisis en profundidad). La entrevista con una integrante del cuerpo periodístico confirma estos objetivos y destaca la necesidad de recuperar en el periodismo los postulados de la comunicación popular, bajo los cuales se autodefine este medio ${ }^{33}$.

La lucha contra la violencia de género y la comunicación desde el feminismo se han incrementado en las comunidades sociodigiales en Argentina, en particular desde la emergencia del movimiento \#NiUnaMenos, una de cuyas fundadoras fue entrevistada para esta investigación. Este movimiento, fundado por mujeres del campo intelectual y periodístico en 2015 , tuvo a través de la masividad de sus convocatorias, tanto digitales como marchas en distintas ciudades, un impacto primero nacional y luego internacional, promoviendo una apropiación por parte de grupos diversos en distintos puntos del planeta, unidos por la contundencia de la consigna. Como manifestaba

${ }^{33}$ Entrevista a Lucía Maina Waisman, La Tinta, 18 de septiembre de 2017. 
Pía López en su entrevista, la construcción se dio inicialmente a través de la consigna principal descripta en un documento difundido en redes sociales y medios de comunicación masivos, pero luego "la calle resultó más feminista que el documento". Esta apropiación popular facilitó el cumplimiento de la finalidad principal del movimiento: "estamos en las redes para salir de las redes" 34 .

\section{Reflexiones finales}

Los conflictos sociales recientes en Argentina, en el marco latinoamericano, pueden indagarse considerando la emergencia de nuevos comportamientos entre las comunidades sociodigitales que confluyen en un discurso común: la resistencia contra la construcción de agenda y sentidos en centros de dominación política y mediática.

Los nuevos proyectos politico-sociales de la autocomunicación de masas en América Latina pueden rastrearse en las nuevas formas de cibermilitancia que, entendemos, se presentan más bien como participación sociodigitalizada, como confluencia entre los mundos online y offline.

La investigación se propuso analizar y presentar aproximaciones teóricas que permitieran interpretar las modalidades de participación y configuración del espacio público de las comunidades sociodigitales. La publicidad de discursos que habilitan estas nuevas comunidades online implican el desplazamiento de prácticas de sentido hacia una nueva forma de convocatoria y construcción de espacios de participación, que se presentan como autónomos en relación a las mediaciones tradicionales de los medios de comunicación masivos. Así, los medios sociales de comunicación digital se constituyen en un nuevo espacio de disputa por el poder de la información en el ecosistema de medios conectivos (Van Dijck, 2016) y reprograman las agendas a la vez que reinterpretan los sentidos, resignificando los temas de interés social bajo una perspectiva militante, de toma de posición.

La cibermilitancia de los MSCD y de otras comunidades sociodigitales como los colectivos vinculados a temáticas de actualidad como

${ }^{34}$ Entrevista a María Pía López, Ni Una Menos, 8 de septiembre de 2017. 
derechos humanos y género, se presenta como un espacio de confluencia de la autocomunicación (Castells, 2009) de la ciudadanía movilizada, a la vez que una posibilidad de convergencia de los múltiples formatos y dispositivos de la cultura de la conectividad (Van Dijck, 2016).

La sociedad civil movilizada por la comunicación en red se expresa en Latinoamérica como un quinto poder (Ramonet, 2011) que disputa al cuarto poder un lugar en el ciberespacio a través de medios alternativos, los medios sociales de comunicación digital. En esta reconfiguración de los entornos comunicacionales se lleva a cabo un empoderamiento ciudadano a través de las agendas compartidas, asociadas a derechos humanos y sociales considerados conquistas populares, como una suerte de operación transpolítica (Trivinho, 2006), que se conjuga en la participación fuera y dentro del entorno mediático, en los nuevos entornos y comunidades sociodigitales.

Sin embargo, permanece aún abierta la cuestión acerca del impacto real de estas comunidades y su accionar en el escenario político e institucional. Las nuevas comunidades sociodigitales representan la emergencia de un contrapoder que se hace visible en las redes, pero para salir de las redes a las calles, incrementando sus posibilidades de influencia. Nos cabe observar con atención los efectos de este proceso y sus complejas transformaciones.

\section{Bibliografía}

Castells, M. (1996). La era de la información. Economía, sociedad y cultura. Vol. 1 México: Siglo XXI.

Castells, M. (2009). Comunicación y Poder. Madrid: Alianza Editorial. Ferré Pavia, C. (2014). El uso de las redes sociales: ciudadanía, política y comunicación. La investigación en España y Brasil. Barcelona: Institut de la Comunicació, Universitat Autónoma de Barcelona.

Foucault, M. (2007). El nacimiento de la biopolítica. Curso en el Collège de France: 1978-1979. Buenos Aires: Fondo de Cultura Económica. Ramonet, I. (2011). La explosión del periodismo. Internet pone en jaque a los medios tradicionales. Buenos Aires: Capital Intelectual. 
Rodríguez, M. y Theiler, E. (2016a). “Construcción de la realidad social desde la participación ciudadana en entornos virtuales y desde los discursos mediáticos". En: RAIGAL. No 2, abril sept. 2016 (pp. 143-150) e-ISSN 2469-1216. Villa María: IAPCS, UNVM. Enlace:

http://raigal.unvm.edu.ar/ojs/index.php/raigal/article/view/1 $\underline{9 / 56}$

Rodríguez, Malvina y Theiler, Elizabeth (2016b). "La realidad sociodigitalizada. Participación ciudadana, redes sociales y medios masivos de comunicación en Córdoba, Argentina" (pp. 325-332). En: Memorias XIII Congreso de la Asociación Latinoamericana de Investigadores de la Comunicación (ALAIC). México. ISSN 2179-7617. Enlace: http://alaic2016.cua.uam.mx/documentos/memorias/GT19.p df

Trivinho, E. (2006, diciembre). A condição transpolítica da cibercultura. FAMECOS, N³1, pp. 91-101.

Van Dijk, J. (2016). La cultura de la conectividad. Una historia crítica de las redes sociales. Buenos Aires: Siglo XXI Editores.

\subsection{Fuentes digitales}

AGENCIA PACO URONDO: www.agenciapacourondo.com.ar Último acceso (U.A.): 20/06/2017.

COSECHA ROJA: www.cosecharoja.org U.A.: 01/06/2017.

ENORSAI: www.enorsai.com.ar U.A.: 03/06/2017.

ENREDACCION: https://enredaccion.com.ar U.A.: 22/06/2017.

INFOSIBERIA: www.infosiberia.com U.A.: 21/06/2017.

IZQUIERDA A DIARIO: www.laizquierdaadiario.com U.A.: 01/06/2017.

LA TINTA https://latinta.com.ar U.A.: 19/06/2017.

NI UNA MENOS: www.niunamenos.com.ar U.A.: 25/06/2017.

NOTIENRED: https://notienred.com U.A.: 20/06/2017. 


\section{(1) \\ Biografía de los Editores}

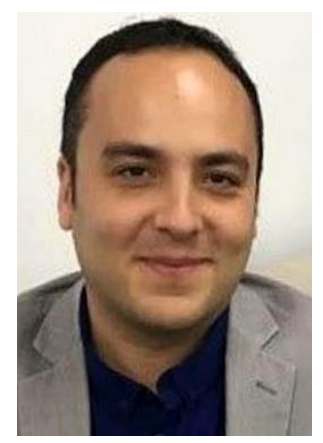

Daniel Barredo Ibáñez es Profesor Asociado de Carrera en el programa de Periodismo y Opinión Pública de la Universidad del Rosario (Colombia), actualmente lidera el proyecto de I+D "Esfera pública y participación ciudadana", financiado por el fondo de proyectos de Gran Cuantía de la Universidad del Rosario. Es autor de más de 100 obras sobre temas vinculados a los medios sociales, la participación política, el discurso organizacional o la comunicación de España, Colombia, México o Ecuador. Es doctor en Periodismo por la Universidad de Málaga, máster y experto en Comunicación y licenciado en Filología Hispánica y en Comunicación Audiovisual por la Universidad de Granada, y cuenta con un índice $\mathrm{H}$ de 11 y está acreditado como INVESTIGADOR SÉNIOR, máxima calificación concedida por el organismo regulador en Colombia.

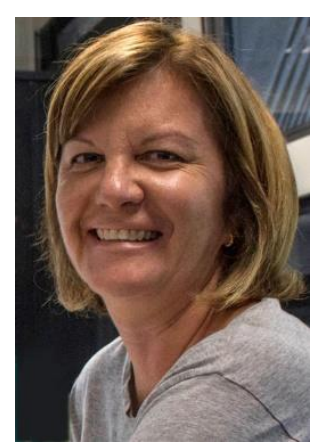

Mágda Rodrigues da Cunha es graduada en Periodismo por la Pontificia Universidad Católica de Rio Grande do Sul (1984), maestra en Comunicación Social (1997) y doctora en Lingüística y Letras (2001), por la misma Universidad. Profesora titular de la PUCRS, donde ejerció como coordinadora de Periodismo, Vice-Directora y Directora de la Facultad de Comunicación Social, Asesora para Asuntos Internacionales e Interinstitucionales y Vicerrectora Académica. En la investigación y en la docencia en comunicación, tiene especial interés por temas relacionados con las tecnologías y los sujetos conectados, desde la perspectiva del consumo y del uso en el ecosistema de los 
medios. Bajo los mismos enfoques, investiga asimismo la radio. Actualmente, es coordinadora de investigación de la Escuela de Comunicación, Artes y Diseño, de la PUCRS, y docente en el Programa de Postgrado en Comunicación. Profesora de la asignatura Lenguajes y Tecnologías de la Comunicación, es líder del Grupo de investigación / CNPq Comunicación, Tecnología y el Sujeto Conectado.

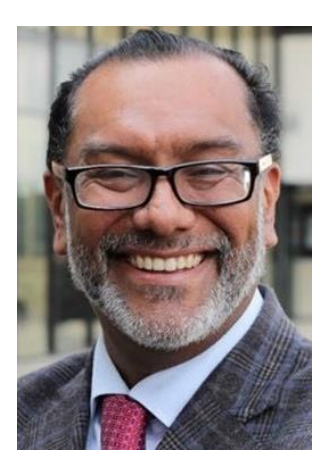

Jorge Alberto Hidalgo Toledo es doctor en Comunicación Aplicada por la Universidad Anáhuac; Miembro del Sistema Nacional de Investigadores Nivel 1 en CONACYT. Vicepresidente de la Asociación Mexicana de Investigadores de la Comunicación, AMIC para el periodo 2017-2019; Vicepresidente Universitario de la Academia Mexicana de la Comunicación para el periodo 2015-2017 y 2017-2020; Presidente del Consejo Nacional para la Enseñanza e Investigación de las Ciencias de la Comunicación, CONEICC para el periodo 20122015; Secretario de la Asociación Católica de Comunicación, SIGNIS México para el periodo 2014-2016. Cuenta con 20 años de experiencia profesional en áreas de comunicación; 4 libros publicados y más de 30 capítulos en libros nacionales e internacionales. Actualmente se desempeña como Coordinador Académico de los Posgrados de la Facultad de Comunicación. 